\title{
Tema:
}

Udvikling af undervisning

- rammer, barrierer og muligheder

D) Dansk

U Universitetspædagogisk T) Tidsskrift

Årgang 7 Nummer 12/2012 


\title{
LEDER
}

\section{Hvad skal vi med forskningen på universiteterne?}

\author{
Frederik Voetmann Christiansen, Institut for Farmakologi og Farmakote- \\ rapi, Det Sundhedsvidenskabelige Fakultet, Kфbenhavns Universitet.
}

Universitetspædagoger, didaktikere og engagerede undervisere interesserer sig mest for "undervisningsstrengen" i universiteternes virke og bliver ofte lidt matte i blikket, når samtalen falder på forskningspolitik. Men forskningspolitikken har betydning for uddannelsernes kvalitet - langt ud over denne eller hin pædagogiske metode, og der er derfor behov for, at vi som interesserede i universitetspædagogik også forholder os til og blander os i spørgsmålet om, hvordan forskningen og undervisningen på universitetet bedst muligt understøtter hinanden. Det kan gøres bedre.

Behovet bliver desto større af, at institutlederes, dekaners og rektorers opmærksomhed på uddannelse og uddannelseskvalitet som regel kan ligge på et meget lille sted. For dem handler det om "de store linjer": Forskningen, erhvervssamarbejdet og de institutionelle strukturer, der sikrer, at institutionen kan klare sig i konkurrencen med de andre. Uddannelse har tendens til at forsvinde af syne eller blive reduceret til studietrinstilvækster, kvalitetssikringsprocedurer og gennemførelsesprocenter. Det kan gøres meget bedre.

Det synes klart for de fleste, at universiteterne bør spille en nøglerolle i løsningen af de store udfordringer, samfundet står overfor i de kommende år. Forskningen er selvfølgelig vigtig her, men det er uddannelserne, vi i særlig grad bør fæste vores lid til. Det er ikke en enkeltstående genial idé eller opdagelse eller et teknologisk fix, der skal sikre velfærden på længere sigt men et generelt højt uddannelsesniveau i befolkningen, der kan bidrage bredt til samfundets velfærd.

Der er i de senere år givet rigtig mange flere penge til forskning bl.a. gennem de såkaldte globaliseringsmidler. Midlerne til uddannelse er også steget men ikke i takt med meroptaget. Hvad værre er, så er de nye midler til forskning udmøntet på måder, der har været undergravende for kvaliteten af uddannelserne. 
Den tidligere regering havde som eksplicit målsætning at øge konkurrencen mellem universiteterne og at ændre fordelingen mellem basismidler og konkurrenceudsatte forskningsmidler.

Det har betydet, at en del af de bevillinger, der tidligere kom i form af basisbevillinger nu er udbudt i konkurrence i bl.a. de statslige forskningsråd. Denne udvikling er i høj grad taget ad notam på universiteterne, der nu bruger enorme ressourcer på at lave ansøgninger til både statslige og private pengekasser. Det har ført til et massivt spild af skatteydernes penge og af de universitetsansattes tid. Succesraterne for at få en ansøgning igennem har været jævnt faldende og ligger pt. på ca. 10 \% i f.eks. de frie forskningsråd. Denne succesrate må formodes at falde yderligere i de kommende år. Den tid, der bruges på ansøgningsskriveriet, er taget fra universitetets kerneopgaver: Undervisningen og forskningen.

Indtil videre er det forskningen i de tekniske, naturfaglige og sundhedsvidenskabelige uddannelser, der har været den store vinder i lotteriet om de eksterne forskningsmidler. Taberne har været uddannelserne, ikke kun på de institutioner hvor man ikke har haft held til at få bevillinger hjem men, paradoksalt nok, også på de tekniske, naturvidenskabelige og sundhedsvidenskabelige uddannelser. Basisbevillingen er den absolut væsentligste del af universitetets indtægt, fordi det er en fri bevilling, der kan bruges til en række forskellige formål. Det væsentligste blandt disse er fastansættelse af personale til både forskning og undervisning. Taxametersystemet er en incitamentstruktur, der alene bidrager til at tydeliggøre uddannelsesaktiviteten på de enkelte institutioner. Det har aldrig været tanken, at taxametersystemet skulle fuldfinansiere uddannelsesaktiviteten, for hele idéen med den forskningsbaserede undervisning er jo netop, at underviserne også forsker. Basisbevillingen er derfor rygraden i universiteternes økonomi og garantien for den forskningsbaserede uddannelse. Men som nævnt er flere og flere midler flyttet over i forskningsrådene, og en stor del af de tilbageværende basismidler er blevet båndlagt på forskellig vis, ikke mindst til medfinansiering af eksterne forskningsprojekter. AC har anslået, at op mod 1/3 af basismidlerne i 2009 var bundet til at sikre gennemførelse af eksternt finansierede forskningsprojekter. Derfor har vi flere steder i landet oplevet, at fastansatte med både undervisning og forskningsforpligtelser afskediges alt imens, der ansættes løstansat personale i store tal til eksterne forskningsprojekter. Der kan i høj grad sættes spørgsmålstegn ved, om det giver os bedre forskning på lang sigt. Utvivlsomt er det imidlertid, at det giver os dårligere uddannelser. De løstansatte postdocs og ph.d.-studerende der ansættes på projektmidlerne har kun få undervisningsforpligtelser og (som følge deraf) begrænset undervisningserfaring. Derfor kan 
de heller ikke gives kursusansvar eller bidrage substantielt til udviklingen af uddannelserne. De er dermed ikke en erstatning for de lektorer, der afskediges, de adjunkter, der ikke får fastansættelse og de lektorater, der ikke genopslås. Konsekvensen er til at tage og føle på for de studerende. På ét fakultet på KU ser det f.eks. således ud: Når en studerende i 2005 gik ind i et auditorium var der ca. 30 \% sandsynlighed for at undervisningen blev forestået af en løstansat (D-VIP, ph.d.-studerende eller postdoc). I 2010 var tallet ca. $45 \%$.

På de humanistiske og samfundsvidenskabelige uddannelser, hvor man ikke har fået nye eksterne midler i et nævneværdigt omfang, har man alligevel mærket presset på basisbevillingerne, og det har flere steder givet sig udslag i nedskæringer på uddannelsernes konfrontationstid og i afskedigelser. Et plaster på såret fik man i 2009, da det laveste uddannelsestaxameter fik et tilskud på 5000 kr. Det kan man så lune sig ved indtil 2013, hvor dette tilskud bortfalder.

Der er brug for et politisk kursskifte, og vi må håbe, at den nye regering vil levere det. Glædeligt er det i hvert fald, at den nye regering tilsyneladende vil lægge større vægt på uddannelse end den foregående. Et tegn på dette er samlingen af de videregående uddannelser under et fælles ministerium. Et andet er, at regeringsgrundlaget sætter ambitiøse mål for hævelse af det generelle uddannelsesniveau for de lange videregående uddannelser. Sidst men ikke mindst, at man "ved tildeling af nye forskningsmidler" vil "sikre, at universiteterne får flere basismidler."

Som universitetspædagoger er vi gode til at stille spørgsmål til undervisningen, og det første og væsentligste spørgsmål er tit: Hvad er målet med undervisningen? Det samme spørgsmål bør vi, universitetsledelserne og Christiansborgpolitikerne stille til forskningen: Hvad er det overordnede mål med forskningen på universitetet? Svaret er ikke ny teknologi, patenter, erhvervssamarbejder, flere ph.d.-studerende, artikler i internationale tidsskrifter, eller et hestehoveds forspring til nabouniversitetet eller kineserne. Det altoverskyggende mål er at bidrage til uddannelsen af exceptionelt dygtige kandidater i store tal. Forskningen er først og fremmest et middel til sikring af gode uddannelser. Ud fra den analyse er de seneste års satsning på forskning forfejlet. 


\title{
Hvidbog om udvikling af universitetsundervisning
}

\author{
Sebastian Horst, specialkonsulent, Institut for Naturfagenes \\ Didaktik, Kфbenhavns Universitet.
}

I denne artikel præsenteres Hvidbog om udvikling af universitetsundervisning der udkom i juni 2011 som et resultat af DUN-konferencen 2011 arrangeret af Institut for Naturfagenes Didaktik på Københavns Universitet.

Hvorfor lave en konference med temaet undervisningsudvikling og hvorfor ligefrem en hvidbog? Det skyldes flere ting. For det første må undervisningsudvikling betragtes som det der helt centralt kendetegner god undervisning. Det er nødvendigt løbende at afstemme undervisningens indhold og form til de studerendes behov. Samtidig ændrer det omgivende samfunds krav til uddannelse sig, og også forskningens fremdrift giver anledning til løbende forandringer i en forskningsbaseret uddannelse. Derfor må undervisningen undergå samme dynamiske udvikling som alt andet på universitetet.

For det andet er det ret tydeligt at der de seneste år er kommet mere fokus på udvikling af undervisning og didaktiske/pædagogiske kompetencer på universiteterne: Der er flere steder indført krav om deltagelse i pædagogiske kurser (fx for ph.d.studerende), der er flere steder puljefinansierede initiativer til at igangsætte udvikling, og endelig begynder universiteternes ledelser også flere steder at tale om hvor vigtigt det er at sikre kvalitetsudvikling.

Men for det tredje oplever vi der stod bag konferencen og arbejdet med at lave hvidbogen, at betingelserne for at udvikle undervisning ikke bliver bedre - faktisk er der flere aspekter der trækker i retning af at gøre det sværere at udvikle undervisningen!

Denne lidt paradoksale situation gav anledning til konferencens - og hvidbogens undertitel: "Rammer, barrierer og muligheder". Den afspejler ønsket om at se undervisningsudvikling i et bredt perspektiv. Udvikling er afhængig af fx økonomiske og organisatoriske rammer og støder lejlighedsvis ind i barrierer - både reelle barrierer og dem som blot synes uovervindelige. Men en tydeliggørelse af rammer og barrierer kan åbne op for bedre muligheder for udvikling af danske universitetsuddannelser. 


\section{En hvidbog for at fastholde og sammenstille}

DUN-konferencens første dag handlede om at dele viden om undervisningsudvikling, mens andendagen fokuserede på, hvordan vi kan skabe bedre udvikling af universitetsundervisning $\mathrm{i}$ form af forskellige tiltag: Individuelle tiltag, institutionelle tiltag og nationale tiltag. Disse diskussioner skete ved slutningen af konferencen og dermed på baggrund af de foregående plenumoplæg og symposier (se programmet på hjemmesiden www.ind.ku.dk/dunk).

For at de mange diskussioner og forslag ikke skulle forsvinde, besluttede arrangørgruppen at forfatte en hvidbog umiddelbart i forlængelse af konferencen. Et første udkast blev udsendt til oplægsholdere og symposieansvarlige allerede dagen efter konferencen, og hvidbogen blev herefter skrevet færdig i løbet af halvanden uge. Den blev udsendt til konferencedeltagere og en række andre nøglepersoner som pdffil 15. juni.

Hvidbogen er efterfølgende udgivet i IND's skriftserie nr. 22/2011: "Udvikling af universitetsundervisning - rammer, barrierer og muligheder" og er tilgængelig på http://www.ind.ku.dk/skriftserie.

I det følgende gennemgås nogle af de vigtigste udfordringer mht. udvikling af universitetsundervisning der beskrives i hvidbogen, og herefter gives et kort sammendrag af hovedanbefalingerne til at skabe bedre undervisningsudvikling.

Efterfølgende har vi modtaget mange interessante tilkendegivelser på hvidbogen alle af positiv karakter. Det lader til at temaet, dilemmaerne og udfordringerne er noget som flere organisationer og institutioner har sat på dagsordenen i denne tid. Vi håber at hvidbogen fortsat kan være til inspiration og gavn inden for det universitetspædagogiske miljø hvor der arbejdes med at udvikle undervisning, og udenfor i det politiske miljø som sætter rammerne for undervisningsudviklingen - og har ansvaret for at disse rammer forbedres!

\section{Uddannelse er det primære samfundsmæssige afkast af universiteterne}

Det er nok rimeligt at sige at $\mathrm{i}$ hvert fald de ældste universiteter i Danmark har været noget fodslæbende i forhold til pædagogisk efteruddannelse af lærerne. Men dette har ændret sig. Universiteterne forsøger faktisk at gøre noget for at styrke undervisningen, og her står udviklingen af adjunktpædagogikum nok som den mest synlige satsning på universiteterne. Således har adjunktpædagogikum over en periode på 10-15 år udviklet sig til nu at være robust og naturligt forankret på mange universitetsfakulteter. 
Hvidbogen slår fast at som hovedregel har deltagerne i adjunktpædagogikum, både adjunkter og postdoc'er, det tilfælles at de enten er eller bliver oprigtigt optaget af undervisning. Deltagerne mener generelt at undervisning er vigtig, og at der er behov for en styrkelse af undervisningen på universiteterne. Og de vil det gerne. Men ofte hænger det ikke sammen med den situation som de er i, hvor incitamentsstrukturerne for at prioritere forskning er langt stærkere end for at prioritere undervisning, og hvor undervisning for fx post.doc.'er typisk kun udgør en lille del af deres arbejdsindhold. Der kan altså på grund af rammerne for universiteterne være klare grunde til at nedprioritere undervisningsudvikling. Denne situation skyldes både de grundlæggende rammer og manglende ledelsesmæssige indsatser.

På grund af det igangværende generationsskifte er adjunktpædagogikum også strategisk vigtig for universitetet. Når de unge forskere/undervisere får en pædagogisk uddannelse, er de med til at præge hvordan undervisning opfattes og praktiseres på institutterne på længere sigt.

Der er dog inden for de seneste år også taget andre initiativer til at styrke kvaliteten af undervisningen. De fleste af disse initiativer er for så vidt fornuftige nok. På et overordnet plan er de udtryk for at universiteterne efterhånden pålægges og påtager sig et ansvar for at underviserne får mulighed for at udvikle sig pædagogisk. Men mange oplever at der i for høj grad er tale om ukoordinerede tiltag og indsatser. Det er også karakteristisk at alle disse nye tiltag er øgede krav til dem der skal forestå undervisningen, samtidig med at kravet om at skaffe eksterne midler til forskning øges.

Hvidbogen argumenterer for at vi må se på selve fundamentet for universiteternes virke, dvs. hvordan midlerne bevilges, og hvordan underviserne ansættes. Det er afgørende at forstå at forskningspolitikken har implikationer for universitetsuddannelserne. Der er derfor brug for at politikerne tænker sammenhængende om universiteterne som steder for både forskning og uddannelse og forstår at ændringer i bevillingssystemet for forskningen har betydning for prioriteringen af undervisningen. Det er nødvendigt at der på det nationale niveau skabes et system som tilskynder til en balancering mellem universitetets tre formål (forskning, uddannelse, formidling/kontakt til det omgivende samfund). Og der er i dag tydelige tegn på at det ikke er muligt at opretholde en god balance på de lokale niveauer.

\section{Indsatser på flere niveauer}

På DUN-konferencen var der fire plenumoplæg til at give en ramme for diskussionerne. To af dem - Thomas Harboe og James Wisdom - er blevet til artikler i dette nummer af DUT, så de skal ikke omtales mere her. De to øvrige af henholdsvis Fre- 
derik Voetmann Christiansen fra Københavns Universitet og Stefan Lindgren fra Lunds Universitet pegede begge på nødvendigheden af indsatser på flere niveauer der trækker i samme retning. I sit oplæg argumenterede Frederik Voetmann Christiansen for at vi i en analytisk model kan se alle aktører i uddannelsesudviklingen fordelt på tre niveauer: Mikro-, meso- og makroniveauet.

Mikroniveauet, eller individniveauet, indbefatter de enkelte undervisere, studerende, de kursusansvarlige m.fl. og handler således om det der sker i den konkrete undervisning. Et eksempel på hvordan man forsøger at skabe undervisningsudvikling på dette niveau, er efteruddannelseskurser af undervisere. Egentlig ved vi kun lidt om effekten af sådanne indsatser. Vi ved at længere kurser har større effekt end korte kurser, men meget tyder på at holdningen i den kultur som underviserne kommer fra, er mere afgørende for om sådanne kurser sætter sig blivende spor i undervisningen, end hvordan efteruddannelseskurset er tilrettelagt. En indsats på mikroniveauet kan godt sætte sig spor hos den enkelte deltager, men skal der ændres i den lokale undervisningskultur, forudsætter det at der her er vilje og ressourcer til at imødekomme forandringerne. Og hermed bevæger vi os over på mesoniveauet som omfatter den sammenhæng som underviserne mv. indgår i.

Mesoniveauet kan have forskellig form: Det kan være et (mindre) institut, en afdeling eller en gruppe defineret på anden vis, fx som alle 1.-årsundervisere på en uddannelse. Dette niveau er særligt interessant da det i høj grad er i dette forum at balancen mellem forskning og undervisning præges. Det er muligvis også dette niveau som det kan være særlig svært at påvirke - både for de enkelte undervisere og for de lokale ledere i miljøet.

Det sidste og det overordnede niveau er makroniveauet som kan være et ledelsesteam, et universitet, et fakultet eller et stort institut. Indsatser fra makroniveauet har den risiko at de let kommer til at virke anderledes end ønsket. Et eksempel på dette er når kvalitetssikringsmekanismer (der måske nok er tænkt som fremmende for god undervisningspraksis) i undervisningsmiljøerne, dvs. mesoniveauet, bliver opfattet som kontrolforanstaltninger snarere end som ressourcer for kvalitetssikring. Dette er der eksempler på er sket med indførelsen af generelle, systematiske kursusevalueringer efter ønske fra ledelsesniveau. For at et sådant tiltag skal virke fremmende for kvaliteten af undervisningen, skal det både optages af den enkelte underviser og indgå i den fælles undervisningskultur som underviserne er en del af.

Det skal understreges at denne mikro-, meso- og makroopdeling er analytisk. I praksis er der flydende overgange mellem niveauerne, og indsatser på ét niveau vil alt andet lige påvirke de andre niveauer. Indsatser på ét niveau forudsætter ressourcer 
og udviklingsvillighed på de andre niveauer. For at skabe varige og forbedrende forandringer i uddannelserne skal indsatserne prioriteres på alle niveauer.

Stefan Lindgren fortalte i sit oplæg på konferencen at man på Lunds Universitet i projektet EQ11 forsøger at gøre op med tanken om at forskning på universiteter og undervisning på universiteter er to adskilte opgaver. Fra øverste ledelsesniveau og hele vejen gennem organisationen søger man en helt anden type følsomhed over for metode- og undervisningsudvikling. Man vil tænke anderledes om den måde arbejdet værdisættes på. Det handler om at arbejde bedre, ikke om at undervise eller forske bedre. En sådan etablering af den universitetsansattes position gør det svært for alle parter at stille spørgsmål ved hvorvidt undervisningsudvikling er for bekostelig og tidskrævende.

Et væsentligt element i dette skifte er en insisteren på et fuldstændigt medejerskab blandt universitets ansatte i formuleringen af en klar og tydelig målsætning om kvalitetsudviklingsprojekternes retning. Således er der vedtaget en definition af forskningsbaseret undervisning der prioriterer et syn på forskning som en proces der foregår, og undervisning der inkluderer de studerende som deltagere. Herfra er der ikke langt til tanken om en forsknings-undervisningsintegration, hvor de studerende bliver betragtet som deltagere i forskningsprocessen.

\section{Mere fokus på fællesskabers undervisningskulturer}

Ifølge hvidbogen skal der især sættes fokus på mesoniveauet - dvs. hvordan man styrker et fællesskab omkring det at undervise forskningsbaseret. Mange nye VIPansatte i Danmark indgår først og fremmest i forskningsfællesskaber. Der er behov for et system hvor det er lige så naturligt for en VIP at indgå i et stærkt og udviklende undervisningsfællesskab. Dette kræver måske nok indsatser fra makroniveauet lige som det selvfølgelig også fordrer en interesse fra mikroniveauet - men der er først og fremmest behov for at fokusere på hvordan vi på mesoniveauet kan skabe undervisningskulturer der understøtter udvikling af undervisning.

Som eksempel beskriver hvidbogen hvad man får af svar når man spørger deltagerne på adjunktpædagogikum ved det Naturvidenskabelige Fakultet på Københavns Universitet om de føler sig som forskere der underviser, eller som undervisere der forsker. Svaret er entydigt: At være ansat som adjunkt eller postdoc er at være ansat som forsker. Det upåagtet at adjunkters og for den sags skyld også lektorers tid som oftest er ligeligt fordelt mellem forskningsopgaver og undervisningsopgaver. Adjunkterne forklarer og begrunder selv den holdning til forskeridentiteten med henvisning til den incitamentsstruktur der er etableret for at sikre en høj forskningsaktivitet. I de mange situationer der opstår hvor man skal prioritere undervisning mod 
forskning, oplever de unge VIP'er ikke at der reelt findes et valg. De bliver nødt til at prioritere forskningsansøgninger og ligeledes den forskningsmæssige grundighed der er forudsætningen for at ansøgningerne løbende bevilges. Således opleves spørgsmålet om undervisningsudvikling ikke som udtryk for manglende vilje men simpelthen som udryk for en organisering på universitetet og i bevillingsstrukturen der udelukkende peger på forskning og på en nedprioritering af undervisningsindsatsen.

\section{Sammendrag af anbefalinger}

\section{Fndring af bevillingssystem til universiteterne}

Der bør udformes et bevillingssystem som giver incitamenter til prioritering af udvikling af universitetsundervisning. En større andel af midlerne til universiteterne ønskes fordelt som basismidler for at sikre muligheder for at skabe undervisningsudvikling. Folketinget bør sikre at forskningsmidler kommer uddannelsesindsatsen til gavn. Det kan ske ved at forskningsbevillinger kobles til uddannelsesaktiviteter.

\section{Publicering af artikler om undervisningsudvikling}

Peer review'ede artikler om undervisning og udvikling heraf bør være lige så meriterende som forskningsartikler.

\section{Udvidelse af taxametersystemet}

Taxametersystemet ønskes udbygget med en andel til finansiering af undervisningsudvikling og evaluering. Pengene skal gives på universitetsniveau, så det er muligt at prioritere på årsbasis.

\section{Andring af stillingsstrukturer for universitetsansatte}

Det ønskes at der i alle stillinger stilles krav til udvikling af undervisningskompetencer. Således bør også postdoc-ansættelser indebære undervisning.

\section{Samarbejde mellem de danske universiteter om en national kompetence-} udviklingsstrategi

De danske universiteter bør samarbejde om udvikling af undervisning, og der ønskes incitamenter hertil fra centralt hold i form af en national kompetenceudviklingsstrategi for universitetsundervisere. Strategien kan udarbejdes i et samarbejde under Danske Universiteter med inddragelse af relevante organisationer, fx DM, DJØF, DSR og DUN. 


\section{Pulje til særlige indsatser for undervisningsudvikling}

Videnskabsministeriet bør oprette en centralt administreret pulje til særlige udviklingsindsatser inden for undervisning.

\section{Centers of excellence}

Der bør oprettes en række "centers of excellence" inden for uddannelsesudvikling således at specialkompetencerne på tværs af universiteterne kan udnyttes.

\section{Tydelige krav og mål for undervisningsområdet fra ledelsesniveau}

Der skal fra ledelsen på alle niveauer, lige fra studieleder, institutleder, dekan og til rektor, være klare mål for institutters/uddannelsers indsats på undervisningsområdet.

\section{Bedre brug af undervisningsportfolio}

De danske universiteter bør i fællesskab udrede hvilke krav der er til undervisningsportfolioer samt hvilke behov de skal opfylde.

\section{Undervisningsudvikling som del af MUS}

Undervisning og udvikling heraf skal indgå som fast element i medarbejderudviklingssamtaler.

\section{Kompetenceudvikling af fastansat videnskabeligt personale}

Der skal lokalt opstilles målsætninger for pædagogisk kompetenceudvikling til fastansatte VIP (lektorer og professorer). Det er oplagt at gøre dette funktionsafhængigt, dvs. at ny funktion og rolle som underviser ledsages af kompetenceudvikling. En incitamentsstruktur i form af løntillæg bør også indtænkes.

\section{Styrkelse af undervisningsfællesskaber}

Den lokale ledelse af undervisningen (kursusansvarlige, studieledelse, institutledelse) skal etablere og understøtte gensidigt forpligtende undervisningsfællesskaber.

\section{Pædagogisk opkvalificering af ledere}

Universitetsansatte med ledelsesopgaver bør besidde pædagogisk indsigt og kompetence. 


\section{Lokale ressourcer og redskaber til at udvikle undervisning}

Den lokale studie- og undervisningsleder skal råde over og anvende ressourcer og redskaber som giver mulighed for at gennemføre udviklingsopgaver. Ledelsen skal medvirke til at god undervisning og undervisningsudvikling bliver anerkendt og synliggjort på lige fod med forskningen, og det kræver både holdnings- og handlingsorienterede tiltag.

\section{Studenterinddragelse i undervisningsudvikling}

Studerende bør som udgangspunkt altid inddrages i undervisningsudvikling.

\section{Langsigtet organisering af den universitetspædagogiske indsats}

Det enkelte universitet skal sørge for en organisering af universitetspædagogiske enheder der sikrer forskningsbasering og en sammenhængende indsats både over tid og på tværs af faglige miljøer.

Sebastian Horst arbejder som projektmanager og specialkonsulent på Institut for Naturfagenes Didaktik, Københavns Universitet. Han var tovholder for planlægningen og afholdelsen af DUN-konferencen $2011 \mathrm{og}$ produktionen af hvidbogen. Til daglig arbejder han med udvikling og evaluering af undervisning og uddannelser, byggeri og indretning af undervisningsfaciliteter. Han varetager også overordnet projektstyring af instituttets projektportefølje og er redaktør af tidsskriftet MONA. 


\title{
International trends and strategies in educational development at universities
}

\author{
James Wisdom, Visiting Professor in Educational Development, Middlesex \\ University, jameswisdom@compuserve.com.
}

\section{Reviewet artikel}

\begin{abstract}
This article considers four areas of educational development work which may become more significant in the future. The range and quality of professional development for teaching in higher education has expanded in many countries, the investment in academic frameworks of outcomes, credits and standards has yet to be exploited, the research into student learning is both productive and challenging to existing structures, and the practice of educational development is becoming more extensive - for example, practitioners are now expected to contribute to institutional strategy as much as to provide support for individual lecturers. The article notes significant changes in assumptions about the relations between students, their teachers and their courses, the need for revised approaches to assessment, and the importance of the professional development of the program leader and team to support the modernization of higher education.
\end{abstract}

\begin{abstract}
Introduction
In this paper I wish to consider four areas of educational development work which are likely to grow in their influence on the practice of higher education. These are 1) changes in the way that academics, lecturers and faculty are supported in becoming professional teachers, 2) developments in the use of learning outcomes and academic frameworks, 3) the impact of some of the work that has been done on our understanding of student learning, and finally 4) the work of educational development within universities and how it can make an impact on improving the experience of learning for students.
\end{abstract}

Developments in these four areas will be significant, not just for educational developers, but also for academics teaching their subjects, managers in departments who are shaping courses and programmes, colleagues across institutions who are supporting student learning (for example, in the library) and for university leaders who are responsible for the strategic development of their institutions. Many of the devel- 
opments are the outcomes of a growing focus on the quality and experience of the student as a learner, and have led to pressures for the re-shaping of existing practices, attitudes and relationships which up to now have served higher education well.

\section{The professional development of higher education teachers}

The International Consortium for Educational Development is made up of the national networks of educational developers from 22 countries. These networks are dealing with a number of issues concerning the professional development of higher education teachers.

The first is the question of compulsory training. Through the Consortium we have identified a few countries (Denmark, Sweden for a time) which have made it mandatory for higher education lecturers to be qualified as teachers. Some national governments have a policy of wanting their lecturers to be qualified, and support initiatives to increase the proportion. In some countries (Holland, for example), university leaders have established their own national policy. In general, individual universities adopt various positions, ranging from ensuring that taking and passing a course is an element in the decision to confirm probation, to offering opportunities and hoping lecturers use them voluntarily. In a world which values professional qualifications, it is hard to believe that the activity of teaching in higher education will remain one which requires no training or qualification other than the possession of subject knowledge.

The second is the question of standards. What does it really mean to be prepared, trained or qualified to teach in higher education? The courses can range from induction measured in days, through short courses taken in weeks, to year-long programmes leading to Postgraduate Certificates perhaps accredited by a national body. Some institutions are offering progression to Diploma or Masters Level and even PhD. In the UK we have seen the growth of the Professional Doctorate as a suitable programme for lecturers looking for the highest qualification.

The core question of standards, as well as the need for comparability and transferability between institutions and now between countries, has led in some cases to the explicit articulation of expectations. The UK has used a Professional Standards Framework since 2006 (UK PSF 2006), the Dutch Rectors have an agreement based on broad standards, and there have been European projects (e.g. Nettle - The Network of European Tertiary Level Educators (Nettle, 2005) exploring these issues. In each case, educational developers have played a significant part, and this will remain an important part of their work in forthcoming years. 
The third is the question of who might want to engage (or be encouraged to engage) with professional development. The "traditional" group has been the new full-time academic members of the university. Once this is established, attention turns to the needs of another group of staff, named in a variety of ways as postgrads, postdocs, visiting tutors, sessional staff, casual employees, adjunct faculty etc. These staff might be supervising tutorials or leading seminars, marking work under supervision, assisting on field trips, tutoring in design studios or occasionally lecturing. In some universities, students might be taught more by them than by full time academics - the professors might be in the prospectus, but the postgrads are in the classroom. Their professional development is an essential part of any university's efforts to improve the quality of the student experience and of course many are hoping to become future faculty. As institutions systematise matters such as contracts, employment status and entitlements, so the scale of activity expected from the educational development centres to support this category of staff is growing.

More attention is now focussed on new academics than on perhaps the most important group - the established lecturers who may have been teaching for many years. The growth in modern pedagogic professional development has been so extensive and so significant that there can now be very different understandings about teaching and assessing between members of even the same department. Many universities have developed progression routes for academics who want careers which move between teaching, research and administration. There are new programmes associated with reflection, portfolio, mentoring, work-based and work-related learning these are the pedagogies most appropriate for established staff who would not be able to attend traditional taught courses. The opportunities are in place for a significant expansion in this work for educational development centres.

In the UK the Staff and Educational Development Association has developed a range of 16 professional development awards which are used by institutions to design programmes for established staff, to match the different roles and responsibilities which academics take through their teaching careers - such as external examining. This same Professional Development Framework (SEDA PDF) recognises that students' learning is affected by their relationships with many more people than simply their teachers, and that a successful academic programme is delivered by a large team of people, beyond the core academic owners. So some PDF awards have been designed for the professional development of those who support learning but are not employed as departmental academics. 
In the UK, the Professional Standards Framework has been able to provide a description of the first and second level of standard (UK PSF 2006). The Framework is designed around six areas of activity, some areas of core knowledge and a set of professional values. The six areas of activity are:

1. Design and planning of learning activities and/or programmes of study

2. Teaching and/or supporting student learning

3. Assessment and giving feedback to learners

4. Developing effective environments and student support and guidance

5. Integration of scholarship, research, and professional activities with teaching and supporting learning

6. Evaluation of practice and continuing professional development.

While the areas of core knowledge and the professional values apply to both levels, those seeking recognition for the first level need only provide evidence of two of the six areas of activity. Therefore level two - which expects all six - has become the de facto standard for the mainstream, fully employed academic member of the university, who needs to understand the role of assessment in the design of modules, courses, and programmes. The "para" academic (postdoc tutor, for example) will typically concentrate on providing evidence of areas 2, 3 or 4 because they will be working within the framework designed by the module leader. SEDA now also expects that all those who are leading and managing the educational processes of institutions - deans, senior managers, even vice chancellors - should have achieved the second level of the professional standard.

However, in many universities there is still insufficient engagement with continuing professional development for teaching. The difficulties here are deep-seated and may result from unexplored assumptions about current practice. The focus on preparation for new academics, for example, has reinforced the apprenticeship induction model, with its implied message that existing practice is satisfactory and that only newcomers need to be trained. National and international reputation lists (for example, THE World University Rankings) are part of a competitive environment which in many cases takes for granted that current practice is best practice.

The educational development community has the responsibility to critique this position; for example, only 27 of the "top 200" world universities are scored for their teaching at over 70\% (THE Top 200). However successful higher education might have been in the past, the models of pedagogic practice which supported it are becoming less suitable for present conditions, and may have little place in the future. 
We must surely focus on using the research into student learning to shape pedagogic practice for the next generation of students.

\section{Developments in the use of Learning Outcomes and Frameworks}

Educational developers have been closely associated with the major initiatives to describe higher education - the use of intended learning outcomes, the construction of clear assessment criteria and the explicit statements of standards. Many universities now have modular programmes and institutional credit frameworks. Europe now has national and international academic frameworks and credit systems which enable its citizens to study beyond their national borders.

Three features of these developments may grow in significance for educational developers, especially in the way institutions learn to use these new approaches. The first feature is that institutional development is now more straightforward to manage. If a university is committed to sustainability, for example, it now has processes for reviewing explicit learning outcomes in its academic quality framework, and can ensure that all programmes have a sustainability element within them.

The second is that institutions are mistaken if they regard the exercise as complete once the framework has been constructed. The real work has only just started. At the local level, new units or modules have to be written to take advantage of the opportunities. At the institutional level, evaluation can reveal the need for significant further development. For example, unless managed very closely, modular frameworks can increase the proportion of students' summative assessment but reduce their opportunities for getting formative feedback. Reducing the number of modules per year, or offering modules across the year rather than within a semester, are two approaches which have been deployed to counteract difficulties with modularised assessment.

The third affects the position of the subject discipline within higher education. The modern graduate is someone who is often seen to be interested in interdisciplinary work and in skills development - both of these are harder to achieve when the programme learning outcomes are created by a department closely focused on its discipline. This is one of the discussions emerging from the work to implement "graduate attributes" (Barrie, 2007).

All three of these issues usually underestimate the amount of educational development work which is required to achieve change which is wholeheartedly shared by everyone involved. 


\section{The impact of research into student learning}

The third area of educational development work which is likely to grow is the impact of the research into student learning. Already this work has taught us a great deal about the relationship between teaching performance and student learning, and in significant ways has separated the two. One of the common narratives of educational development is that, while it may have had its origins in work on helping teachers improve their teaching, it has made its most significant contributions when it turned its attentions to how students learn and the impact of the whole teaching, learning, and assessment environment within which they learn (Ashwin, 2006; ETL, 2001-4)

We have four instruments which have been developed from the research and which have helped us to better understand student learning. The Course Experience Questionnaire has helped us focus on the significant elements in the student's whole experience of learning, and how they interrelate (Ramsden, 2003). The Approaches to Studying Inventory (ASI, 2000) has shown how we can design courses and assessment to increase the proportion of students intending to take a deep approach to their learning. The Approaches to Teaching Inventory (Prosser \& Trigwell, 1999) has helped us understand how teachers change their intentions and strategies for teaching according to the context in which they perceive themselves. The work around the Structure of Observed Learning Outcomes (Biggs \& Tang, 2007) has equipped us to work more effectively with learning outcomes, and has contributed to a deeper understanding of how the act of teaching may be as much about course design as about classroom performance.

One of the outcomes of this research is a renewed understanding of the significance of assessment in determining the quality of student learning (see the TESTA project). This has coincided with depressing expressions of instrumentalism from students ("if it won't be in the exam, I won't bother to learn it") which is often described as a new feature associated with the expansion of higher education - though this author can remember it as commonplace in the 1960s. It can be tracked through the "Strategic Approaches to Learning" scale of the Approaches to Study Inventory (ASI, 2000). What is more worrying, however, is the link between instrumentalism and consumerism - the notion that students are paying for their degree and are entitled to the respect due to a customer (who is, of course, always right). In the UK, this position has been caricatured by the President and Political Officer of the National Union of Students (Streeting \& Wise, 2009). 
One of the responses to the notion of "student as consumer" is the development of the concept of student engagement. In the UK this has been supported by a project conducted by the National Union of Students, with an associated web site. A model of this concept (Bols and Freeman, 2011) suggests a direction of travel from Consultation (engaging students in discussions on a deeper level than the ubiquitous end-ofmodule questionnaires), through Involvement (with students taking a more active role in shaping their learning and teaching experience), through Participation (with students making decisions about shaping the curriculum) and reaching Partnership (notions of joint ownership of the processes of learning and teaching).

At present the culture of higher education is still based on ownership of both knowledge and process solely by academics. Nevertheless, one of the outcomes of describing higher education through learning outcomes, assessment criteria, and explicit standards is that lecturers and students have a common platform for discussion about both content and process. Although it is undeniable that the language in which modern descriptions are expressed is sometime impenetrable to students and often to academic colleagues, the more students understand the processes within which they are expected to function, the better will be the quality of their learning and their overall experience.

The developments in research into learning, in understanding the role of assessment in course design, and in student engagement, are now part of the context in which the programme leader and the team is expected to operate. Higher education in the future will be designed by this group of people, especially the design of modern assessment processes which both drive learning and enable students to give good evidence of their achievement of the intended learning outcomes. The programme leader role is likely to evolve into the most important, and the most testing, position in universities. The educational developer has a major contribution to make in the development of the modern programme leader and the team.

\section{Educational development within universities}

As educational development work has developed, so the role of the educational development centre in institutions has changed as well. Educational developers have been moving from working with individual colleagues on teaching behaviour in class to working at institutional level in shaping the development of the institution.

David Gosling, in his latest survey for the UK Heads of Educational Development Group (Gosling, 2008), concludes that there are now two main areas of work: 
(1) the professional development of staff relating to learning and teaching and other academic duties (preparing for research), and

(2) a shared strategic responsibility for implementation of the learning, teaching and assessment strategy, encouragement of innovation, and enhancing teaching quality.

One of the key stages has been the focus on institutional learning and teaching strategies (Gibbs, 2000; 2001; Wisdom, 2008). Developed as a response to the apparent ineffectiveness of large national funded enhancement projects, the creation, implementation and monitoring of these strategies has deepened the relationship between heads of centres and the institution's senior management.

A survey of Australian centres (Holt et al., 2011) identified four critical factors in whether a centre was recognised and valued:

- Clarity of role and direction

- Shared understanding of purpose with the institution

- Capacity and capability to achieve purpose

- Ability to demonstrate value

The survey also identified the two areas most in need of improvement:

- Academic professional development for sessional and on-going faculty teaching staff

- Academic professional development for leaders in learning and teaching

Holt et al also identified ten leverage points in any relationship between a centre and its university. The preparation of new continuing academic staff and a compulsory casual teaching development programme are mainstream processes in many institutions (and Gosling shows them to be widespread in the UK). The notion of compulsory for "casual" but not for "new continuing" is interesting. In a survey of 85 UK institutions in 2010, Gosling (2010) found that $62 \%$ had made it mandatory for new continuing staff to complete a Postgraduate Certificate. Just-in-time professional development addresses the major issue of pedagogic support for the existing, established academics, and recognises that new forms of delivery have to be devised. Supporting teaching excellence through awards and fellowships is one of the mechanisms for raising the profile of teaching and encouraging enthusiast activity - including teaching performance in promotion criteria is often linked to this leverage point as well. However, the location of promotion prospects firmly within the research culture, and the inexperience of the awarding panels for promotion and fellowships in teaching, have made this a slow process. 
Holt et al offered three leverage points which relate to the strategic development of the institution: New visions/new plans, strategic funding for development, and renewing leadership. These map closely to the data noted in Gosling's UK study, and to the argument in this paper. Two other leverage points - disseminating exemplary practices online, and the recognition and use of education experts - have been components for some time of many educational development centres' work, and their effectiveness can be enhanced by encouraging activity around the final leverage point - forming communities of practice.

\section{Conclusion}

As the proportion of academic teachers who are engaged in their own professional teaching development grows, so will the quality and depth of the analysis and understanding of the prevailing models of higher education teaching. The focus must not be solely on classroom practice - it will need to embrace institutional frameworks and policies, because these have significant effects on the quality of student learning. Educational developers have a major role to play in shaping practice at all levels of the institution. In reforming higher education for the next generation, one of the key areas - signalled in some of the most interesting research - is the design not just of the individual modules or courses, but of the overarching programme of study. Programme leaders and the programme teams, supported in as many ways as possible by educational development, will be carrying a great responsibility for the future.

James Wisdom is a higher education consultant, specializing in educational development and evaluation. He is the President of the International Consortium for Education Development and a Visiting Professor of Educational Development at Middlesex University. He has been a Co-Chair of the Staff and Educational Development Association and is the Editor for the SEDA Series published through Routledge. He often contributes to programs for the professional development of academic staff.

\section{References}

Ashwin, P. (2006). "The development of learning and teaching in higher education: the changing context", in Ashwin, P. (ed). Changing Higher Education: The Development of Learning and Teaching. Routledge.

ASI (2000). Bibliography of Studies Using or Conceptually Related to the Approaches to Studying Inventory (ASI), Revised Approaches to Studying Inventory (RASI), Approaches and Study Skills Inventory for Students (ASSIST): http://www.ed.ac.uk/etl/questionnaires/bibliographyASI.html

(Accessed 3/6/2011).

Barrie, S. C. (2007). "A conceptual framework for the teaching and learning of generic graduate attributes", in Studies in Higher Education, 32:4, 439-458. 
Biggs, J., \& Tang, C. (2007). Teaching for Quality Learning at University. 3rd Edition. Buckingham: SRHE \& Open University Press.

Bols, A., \& Freeman, R. (2011). Engaging students in shaping their curriculum", in Educational Developments 12. 2; Staff and Educational Development Association, London.

ETL (2001-4). Enhancing Teaching-Learning Environments in Undergraduate Courses: http://www.etl.tla.ed.ac.uk/project.html (Accessed 11/7/2011).

Gosling, D. (2008). Educational Development in the UK. The Heads of Educational Development Group:

http://www.hedg.ac.uk/documents/HEDG Report final.pdf (Accessed 3/6/2011).

Gosling, D. (2010). "Professional development for new staff - how mandatory is your Post Graduate Certificate?", in Educational Developments, 11.2. SEDA, London.

Gibbs, G. (2000). "Learning and teaching strategies: the implications for educational development", in Educational Developments, 1.1. SEDA, London: http://www.seda.ac.uk/resources/files/publications 44 eddevs1 1.pdf (Accessed 3/6/2011).

Gibbs, G. (2001). "The impact of institutional learning and teaching strategies on the nature of educational development", in Educational Developments, 2.4. SEDA, London: http://www.seda.ac.uk/resources/files/publications 37 eddevs2 4.pdf (Accessed 3/6/2011).

Holt, D., Palmer, S., \& Challis, D. (2011). “Changing perspectives: teaching and learning centres' strategic contributions to academic development in Australia", in International Journal for Academic Development, Taylor and Francis.

National Union of Students project on Student Engagement: http://www.nusconnect.org.uk/campaigns/highereducation/studentengagement-hub/nus-heaproject/ (Accessed 3/6/2011).

Nettle (2005). http://www.edshare.soton.ac.uk/7337/ (Accessed 12/6/2011).

Prosser, M., \& Trigwell, K. (1999). Understanding Learning and Teaching: The Experience in Higher Education. Buckingham: SRHE \& Open University Press.

Ramsden, P. (2003). Learning to Teach in Higher Education. 2nd Edition. London: RoutledgeFalmer.

SEDA Professional Development Framework. http://www.seda.ac.uk/pdf.html (Accessed 3/6/2011).

Streeting, W., \& Wise, G. (2009). Rethinking the Values of Higher Education - Consumption, Partnership, Community?, The Quality Assurance Agency for Higher Education:

http://www.qaa.ac.uk/Publications/InformationAndGuidance/Documents/Reth inking.pdf (Accessed 11/7/2011).

TESTA (Transforming the Experience of Students through Assessment). http://www.testa.ac.uk/.

THE World University Rankings. http://www.timeshighereducation.co.uk/worlduniversity-rankings/ (Accessed 11/7/2011). 
THE Top 200. http://www.timeshighereducation.co.uk/world-universityrankings/2010-2011/top-200.html (Accessed 11/7/2011).

UK Professional Standards Framework (2006).

http://www.heacademy.ac.uk/assets/documents/rewardandrecog/ProfessionalS tandardsFramework.pdf (Accessed 3/6/2011).

Wisdom, J. (2008). "Interview with Graham Gibbs", in Educational Developments.

9.1. SEDA, London:

http://www.seda.ac.uk/resources/files/publications 12 eddev9 1.pdf (Accessed 3/6/2011). 


\title{
Nyudvikling af projektarbejdsformen på RUC - beskrivelse og analyse af et eksperiment: "Antologieksperimentet"
}

\author{
Sфren Dupont, lektor, Institut for Psykologi og Uddannelsesforskning, \\ $R U C$. \\ Artiklen beskriver og analyserer et undervisningseksperiment ved RUC, \\ som udvider og udvikler projektpædagogikken i felterne mellem den enkel- \\ te projektdeltager og de fxlles grupperinger, som studerende indgår $i$ på \\ RUC. Der redegøres for projektets opbygning omkring en klyngestruktur, \\ og der knyttes an til laringsteoretikerne Etienne Wenger og Donald \\ Schön. Desuden inddrages aktionsforskning.
}

\begin{abstract}
"Gensidige relationer mellem deltagere er i det virkelige liv komplekse blandinger af magt og afhængighed, lyst og smerte, ekspertise og hjælpeløshed, succes og fiasko, overflod og afsavn, alliance og konkurrence, velvære og kamp, autoritet og kollegialitet, modstand og eftergivenhed, vrede og ømhed, tiltrækning og modvilje, sjov og kedsomhed, tillid og mistænksomhed, venskab og had. Praksisfællesskaber har det hele". (Wenger, 2004: 95)
\end{abstract}

Ved forårssemestrets begyndelse i 2011 blev et eksperiment og forsøg med udvikling af projektarbejdsformen ved RUC sat på skinner ved studiet Arbejdslivsstudier, som er et tværfagligt og tværvidenskabeligt samarbejde mellem forskellige faglige miljøer ved RUC: Pædagogik, TekSam, Psykologi og Virksomhedsstudier.

Den gængse projektarbejdsform ved RUC udgøres af den enkelte projektgruppe, hvortil der er knyttet en vejleder, som følger gruppen gennem projektforløbet ofte gennem et semester. Det er formentlig unikt ved RUC som universitet, at stort alle studerende hvert år begynder deres studier med dannelse af projektgrupper. Det skyldes, at $50 \%$ af undervisningen ved RUC skal gennemføres i projektarbejdsformen.

RUC har i snart 40 år koncentreret sig om at sætte den studerende i centrum, at skabe studentercentreret læring. Det er RUC ikke blevet verdensberømt for; det er derimod 
den australske psykolog og forfatter John Biggs. Han har gjort sig til talsmand for en teori, der hviler på et grundlag, som kaldes for 'constructive alignment'.

Der er to områder, der er centrale at fremhæve inden for constructive alignment/tilpasning:

- De studerende konstruerer mening ud af det, de gør for at lære.

- Læreren/vejlederen tilbyder rammer for den planlagte læring og de planlagte læringsresultater.

Ud over constructive alignment er Biggs nok mest kendt for at have udviklet den såkaldte SOLO-taksonomi. Denne kan ifølge Biggs bruges til at vurdere kvaliteten af læringsresultater.

Constructive alignment optræder første gang hos Biggs i 1999. Den bog fra Biggs hånd, der har haft størst indflydelse på udviklingen universitetsundervisning, er nok "Teaching for Quality Learning at University", der er udkommet i tredje udgave med Catherine Tang som medforfatter.

Siden 1999 har Biggs' teori været anvendt i store dele af den universitetspædagogiske forskning over det meste af verden - også i Danmark. Biggs' teori er langt fra uden problemer, og den bør såvel kritiseres som udvikles. Hanne Leth Andersen, prorektor ved RUC, har i artiklen 'Constructive alignment' og risikoen for en forsimplende Universitetspædagogik" såvel anerkendt som kritiseret Biggs. Man kan sige, at RUC udvider Biggs bl.a. ved, at det på RUC ikke blot drejer sig om at sætte den enkelte student $\mathrm{i}$ centrum men om at sætte studentergruppen i centrum.

Sat op i en idealform forløber det gængse projektforløb på RUC ved basisstudierne og i bachelorstudierne på følgende måde: 


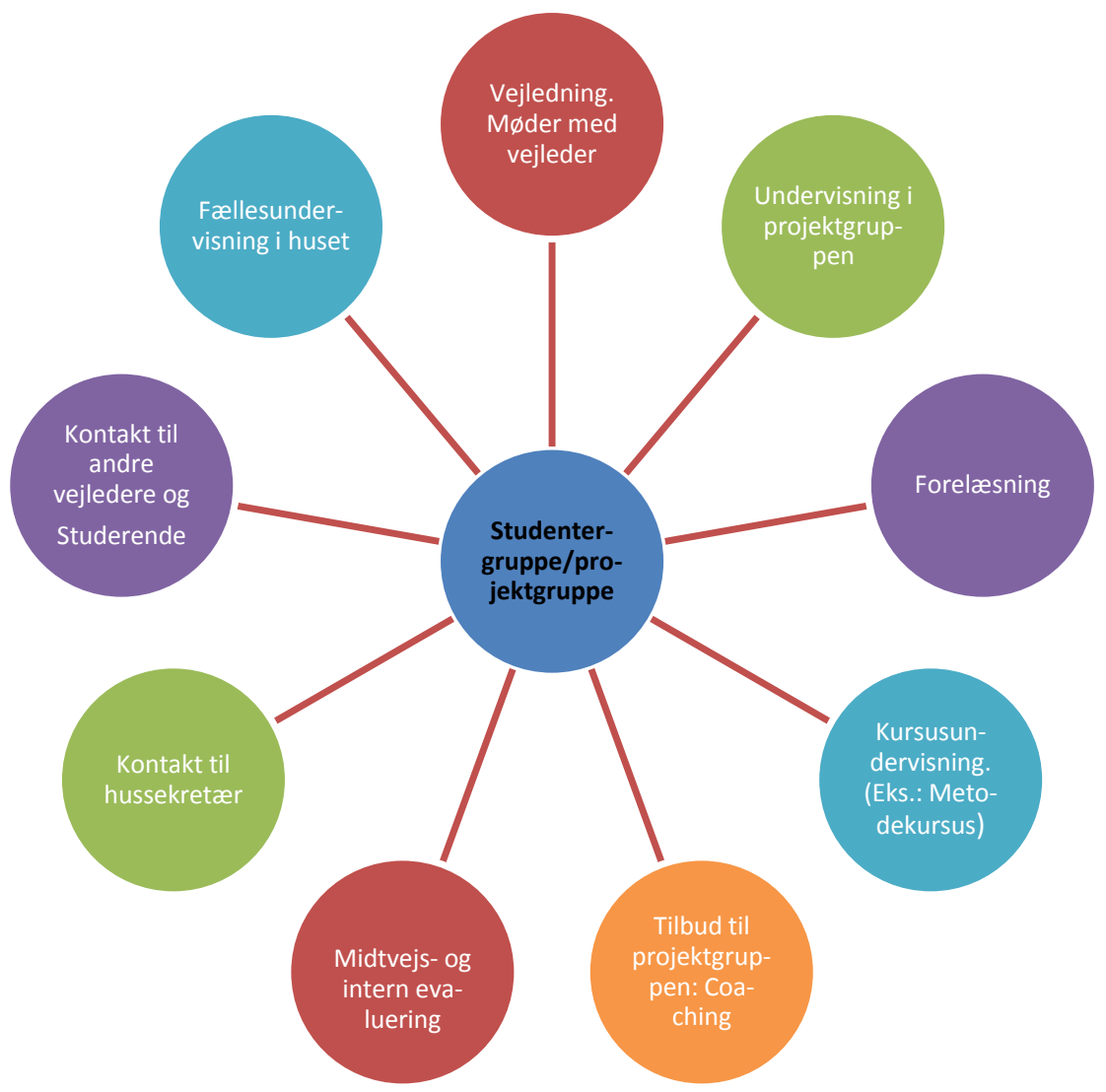

Figur 1: Idealtype for projektforløb på RUC

Det nye i det såkaldte antologiprojekt blev især, at flere grupper på samme tid i et fælles forløb hen over ét semester blev sat i centrum. I de fleste andre projektforløb på RUC er det den enkelte projektgruppe, der er sat i centrum. I antologiprojektet blev der skabt rammer for, at flere projektgrupper på samme tid og i et fælles forløb, kom til at arbejde sammen.

\section{Antologieksperimentet og dets opbygning}

I gennem efterårssemesteret 2010 havde underviserne og de studerende sammen $\mathrm{i}$ mindre skala forsøgt sig med enkeltstående små forsøg og eksperimenter, og det blev besluttet fra forårssemestret 2011 at starte et større eksperiment med intention om at bidrage til fornyelsen af projektpædagogikken ved RUC, bl.a. fordi mange studerende oplever en vis træthed og ambivalens i forhold til den gængse projektarbejdsform, især når de studerende begynder på kandidatuddannelserne ved RUC. De studerende har på dette tidspunkt gennemført 7-8 meget omfattende projektforløb, og derfor oplever flere studerende behov for fornyelse. Derfor skønnede en række lærere ved studiet Arbejdslivsstudier, at et udkast til fornyelser ville være på sin plads. 
På RUC har rektor en såkaldt "Udviklingspulje", der ifølge vedtægterne blandt andet skal anvendes til udvikling, forsøg og eksperimenter. Det blev fra lærergruppens og studenternes side besluttet at søge i denne pulje, og eksperimentet blev understøttet med et større beløb, ligesom der blev bevilget økonomi til en omfattende evaluering af projektet, som skulle gennemføres af UniPæd (Den universitetspædagogiske enhed ved RUC). Evalueringen blev bygget op over en række observationer, 2 fokusgruppeinterview med de studerende, et spørgeskema til alle de studerende, et spørgeskema til censorerne samt andet materiale, der er indgået i kurset.

I slutningen af januar 2011 blev der afholdt møde med de studerende på det såkaldte K1-modul, som er det første modul på Arbejdslivsstudier efter bachelorgraden. På mødet blev grundstrukturen i projektet præsenteret, men der manglede noget. Det var ikke helt muligt at samle eksperimentet i en overskift/titel - indtil en studerende udbrød:

"Jamen det skal da hedde "Antologieksperimentet".

Hermed blev der leveret en metafor, som samlede en stor del af intentionerne i projektet, som bl.a. var orienteret mod det at arbejde med en såkaldt klyngestruktur i projektarbejdet.

En klynge kan i forhold til projektarbejde skitsemæssigt opregnes som nedenfor, hvor der med udgangspunkt i klyngens deltagere dannes en række projekter/projektgrupper, hvortil der er tilknyttet såvel kurser, som læsegrupper og forelæsninger alt sammen med inddragelse af de ønsker, de studerende i samspil med vejlederne måtte have.

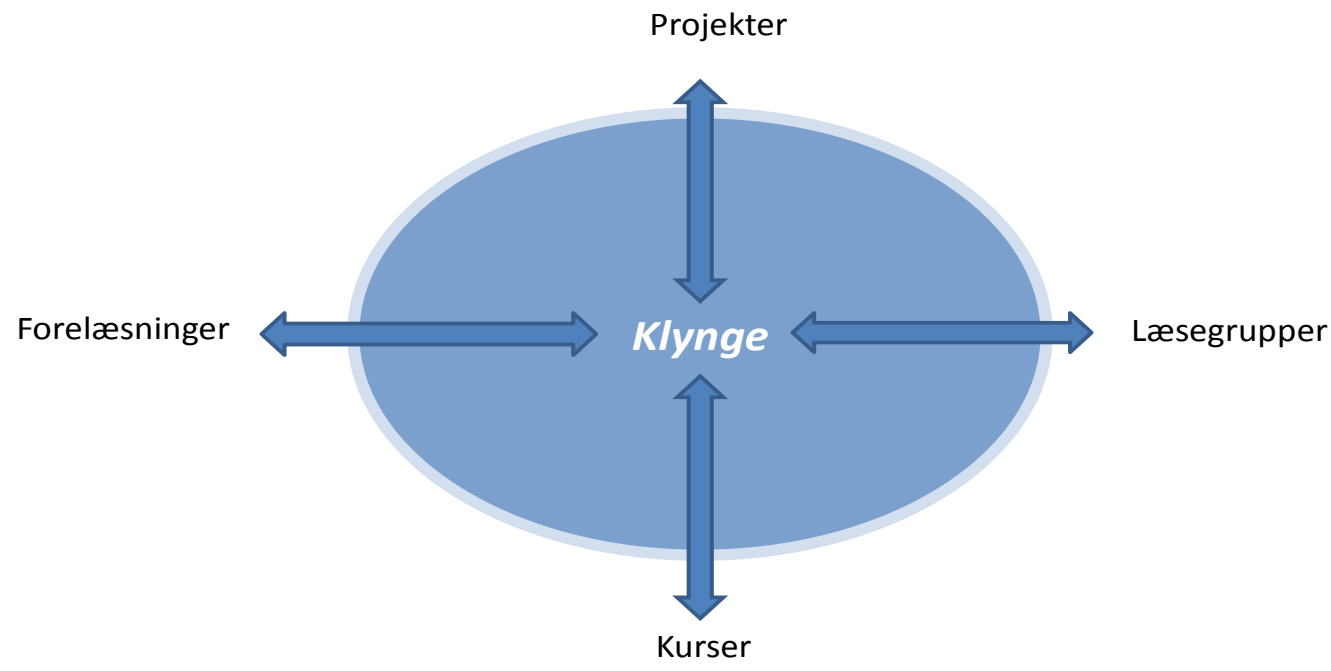

Figur 2: Den traditionelle klyngestruktur på RUC 
En klynge kan defineres som:

1. En enhed af undervisere og studerende, som ikke kun er én projektgruppe.

2. En samling af forskellige undervisnings- og læringsformer: eksperimenter, forelæsninger, kurser, diskussioner, ekskursioner etc.

Der har på RUC været eksperimenteret med mange forskellige elementer i klyngestrukturen.

Thomas Gitz-Johansen, Kim Rasmussen og Trine Wulf-Andersen, alle tilknyttet Institut for Psykologi og Uddannelsesforskning ved RUC, skriver i den forbindelse om klyngeundervisning, at den "er tænkt som en undervisningsform, der på en gang søger at understøtte projekterne, give breddeviden og større overblik, samt lade projektgruppedeltagerne indgå i en anden og social kontekst end projektgrupperne selv gestalter." (Wulf-Andersen et al., 2007: 34).

I "Antologieksperimentet" ved Arbejdslivsstudier blev selve strukturen i projektet/eksperimentet fastlagt som skitseret nedenfor:

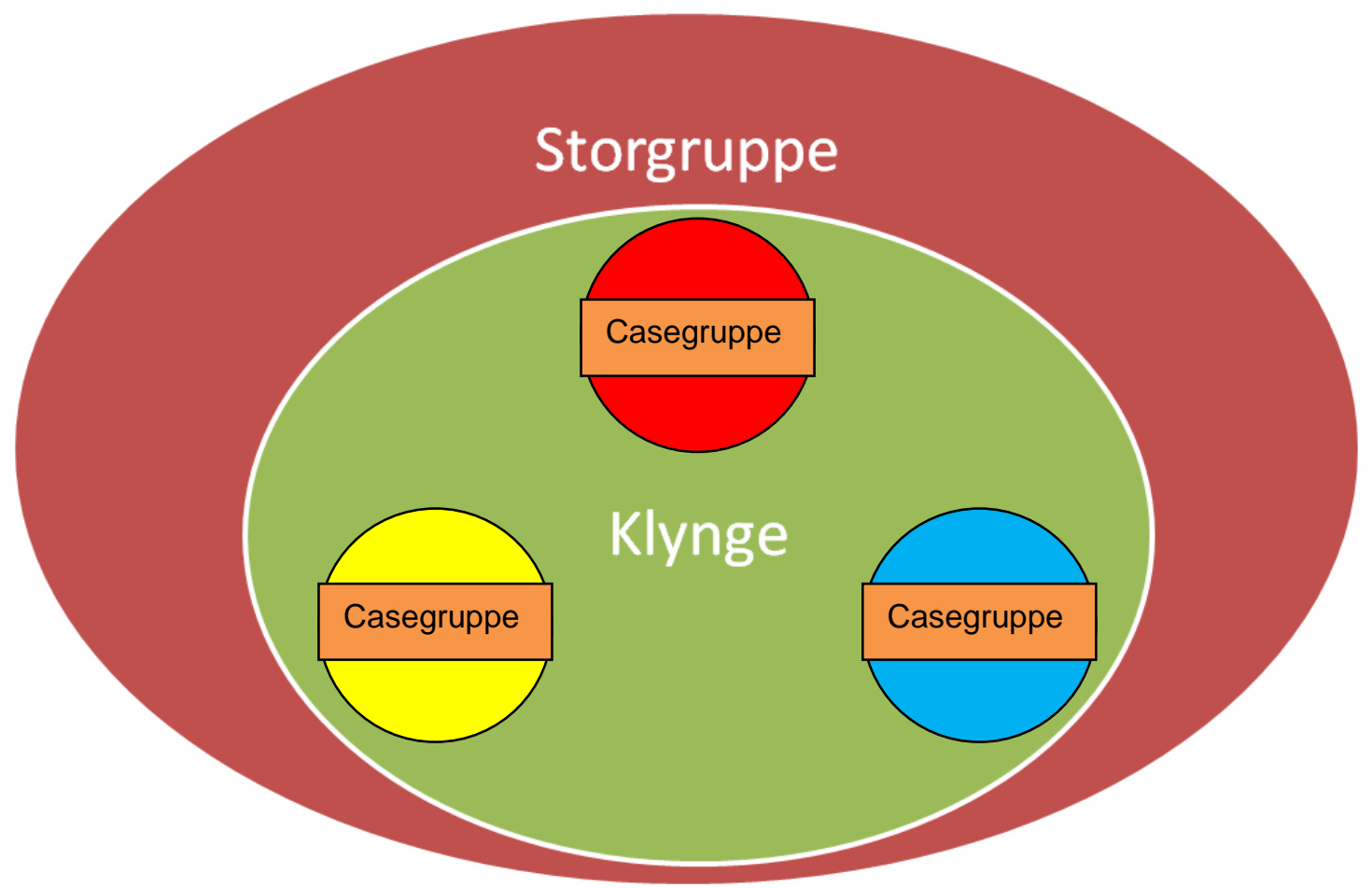

Figur 3: Antologiprojektets opbygning 
Her udgør storgruppen det samlede antal studerende på kandidatmodulet. Storgruppen bestod af 52 studerende.

Med udgangspunkt i storgruppen blev der derefter dannet 4 klynger i en gruppedannelsesproces. Den fælles overskrift på gruppedannelsesprocessen, som de studerende alle skulle forholde sig til, var: Forandring og involvering i forandring. Med udgangspunkt heri arbejdede de studerende sig - med støtte fra sidelinjen fra vejlederne - frem mod en række temaer, som en gruppe studerende (altså en klynge af studerende) ville arbejde med. På den baggrund blev der dannet 4 klynger med følgende temaer/overskrifter/titler:

1. Demokratisering og forandringsprocesser.(14)

2. På vej mod det gode arbejde. (17)

3. Bæredygtig innovation. (14)

4. Faglighed i forandring. (7)

Parenteserne viser hvor mange studerende, der var i den enkelte klynger.

Det skal understreges, at antologiprojektet udgjorde det samlede studieforløb for de studerende gennem et helt semester. Projektet udgjorde således 30 ECTS point.

Herefter blev der inden for de enkelte klynger dannet en række casegrupper, som på caseagtig vis arbejdede med de ovennævnte klyngers overskrifter.

Der var tilknyttet to kurser til modulet. Kurserne understøttede på forskellig vis arbejdet i klyngerne og casegrupperne. Det ene kursus omfattede tematikken "Arbejdslivets problemstillinger og de nye reguleringsformer" og det andet kursus arbejdede under overskriften: "Forandringsprocesser og forandringsmetoder i arbejdslivet". I begge kurser indgik der såvel videnskabsteoretiske som metodiske problemstillinger.

Vejledergruppen opfordrede til, at de enkelte klynger diskuterede ledelse og arbejdsformer i klyngen. Dette blev endvidere betragtet som en god øvelse i forhold til de arbejdsformer, de studerende kunne forvente at møde på arbejdsmarkedet efter deres kandidateksamen.

Det blev også fremhævet som væsentligt, at de enkelte klynger og casegrupper diskuterede hvilke forventninger, de måtte have til vejlederens rolle i forløbet. Det fremgår af den efterfølgende evaluering, at denne del af projektet ikke blev gennemført i tilstrækkeligt omfang. Det er beklageligt, da det er her nogle af de største udfordringer på vejledersiden/lærersiden lader sig identificere. Mere om dette lidt senere. 
De studerende blev endvidere opfordret til at gøre sig klart, hvad der skulle fastlægges af retningslinjer for hvad, der som minimum skulle ydes af arbejdsindsats af den enkelte for at kunne deltage i gruppens arbejde.

I projektet blev klyngen gjort ansvarlig for det samlede produkt, men det meste materiale blev produceret i undergrupper - i casegrupperne. Det fratog dog på ingen måde klyngen for ansvaret, snarere tværtimod, det forstærkede og udbyggede det samlede ansvar, som klyngen havde. Der blev holdt ugentlige møder i klyngerne, hvor alle casegrupperne altså mødtes og diskuterede på tværs af casegrupperne i klyngen. Vejlederne/lærerne deltog ofte i disse møder.

\section{Antologien}

I de enkelte klynger skulle de mindre casegrupper hver for sig udvikle og arbejde med en case under det overordnede tema for klyngen, men selvfølgelig med forskellige tilgange og med forskellige tematikker bragt i spil.

Klyngen skulle producere en antologi bestående af bidrag fra alle de enkelte casegrupper. På den måde skulle antologien bygges op over casegruppernes forskellige bidrag til antologien

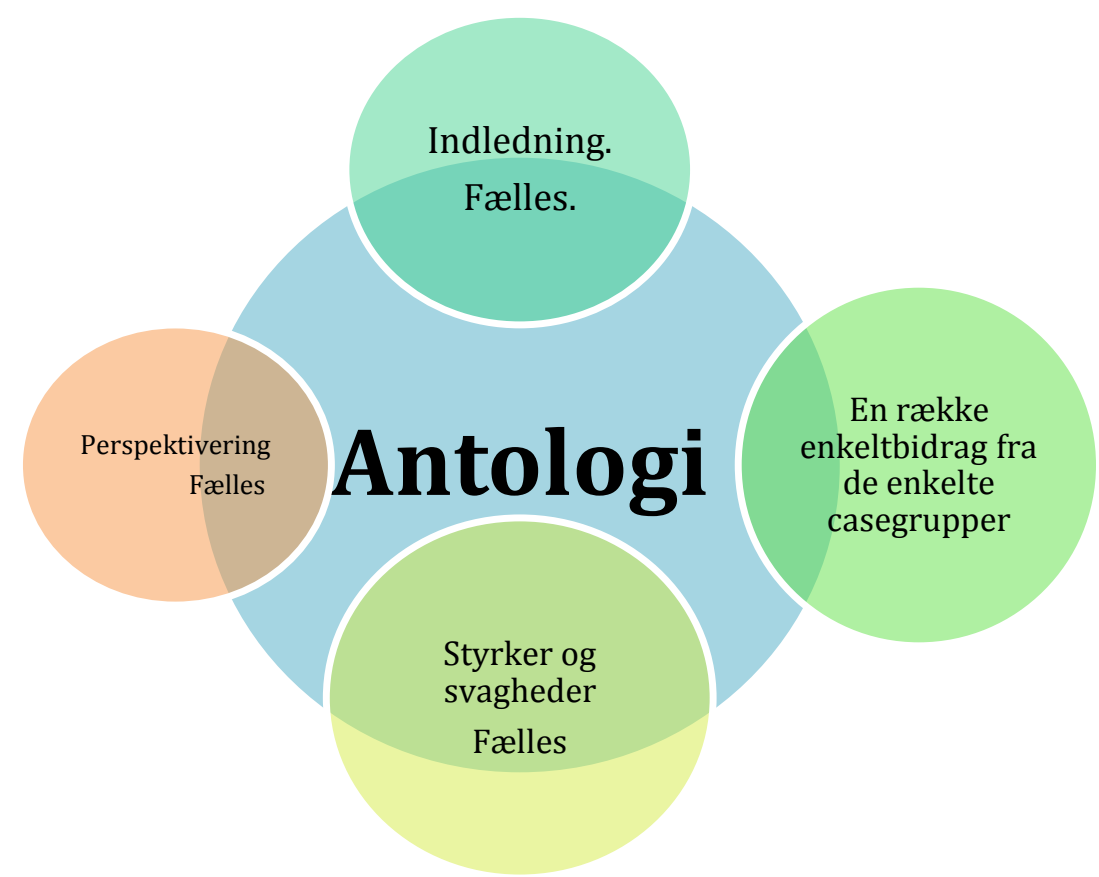

Figur 4: Antologiens opbygning i antologiprojektet 
Antologien skulle fra forskellige vinkler belyse specifikke forandringer og involveringer i arbejdslivet. Det involverede både teoretiske og empiriske studier og kritisk distance, metodisk refleksion, og frem for alt så udfordredes i høj grad evnen til samarbejde mellem de enkelte studerende i casegrupperne, casegruppens relation til klyngen og de fælles relationer mellem alle casegrupperne i klyngen. Sagt på en anden måde: Forholdet mellem den enkelte studerende og frllesskaberne blev virkelig sat på prøve og til udvikling.

De studerende skulle altså ikke blot tænke og agere i forhold til en enkelt projektgruppe, de skulle tænke på tværs af projektgrupper og med udgangspunkt heri producere et fælles produkt som rakte ud over det enkelte projekt.

Antologien måtte max fylde 200 sider. Der blev opfordret til, at de studerende i forhold til antologien nedsatte en redaktionsgruppe og diskuterede, hvilke beføjelser denne gruppe skulle have. En vanskelighed, de eksempelvis skulle tage stilling til, kunne være, hvordan de enkelte casegruppers indspil til antologien skulle bearbejdes i forhold til en fælles linje: Indledning, evt. teori, evt. metode, rød tråd, afslutning, beskrivelse af de enkelte gruppers bidrag etc. Alt dette for at skabe større sammenhæng i processen.

Af disse årsager blev det også forventet, at klyngen undervejs i processen udarbejdede en logbog, der indeholdt de løbende erkendelser under casearbejdet. Logbogen kunne også tjene som grundlag for den fremadrettede planlægning af opgaver og kunne bruges til at afdække, hvor klyngen stod og hvilken vejledning, der var brug for.

Da formidling spiller en central rolle i det pågældende studiemodul - K1 - blev der lagt op til at reflektere over, hvordan viden evt. kunne deles internt i klyngen, med vejlederen, i casegruppen, med de andre klynger og til eksamen. Det blev anbefalet, at der i antologien blev produceret et afsnit om, hvordan klyngearbejdet var gået, set i et læringsperspektiv. De studerende udnyttede og arbejdede med dette på forskellig vis. Flere ting blev anvendt, blandt andet logbog, referater af møder, fremtidsværkstedet og forskellige it-bårne redskaber til at skabe vidensdeling, herunder facebook, hvor de studerende løbende har indgået aftaler, diskuteret og således har brugt facebook som et socialt redskab. Endelig har de studerende opfattet den del af evalueringen, der bestod af fokusgruppeinterview, som en god anledning til at få reflekteret over egen læring.

\section{Eksperimentets læringsmål}

Det overordnede formål med eksperimentet var som allerede nævnt at komme tæt på forandringsprocesser i arbejdslivet, hvor forståelse af konteksten er central. 
Lærergruppen bag eksperimentet definerede en række læringsmål for "Antologiprojektet". De lød som følger:

1. Etablere et kritisk analytisk perspektiv på forandringsprocesser og:

2. Få indsigt i og opøve erfaringer med at få en stor kompleks projektgruppe til at fungere

Hertil kom en række praktiske målsætninger, der lød som følger:

1. Skabe mulighed for, at projektgrupperne kan involvere sig tidligt $\mathrm{i}$ forandringsarbejde.

2. Skabe et tættere studiemiljø.

3. Udvikle studenternes projekterfaringer.

Vi kan til læringsmål og praktiske mål ovenfor her tilføje, at intentionen fra undervisernes/vejledernes side også har været at forbedre undervisningen ved hjælp af forandring, sætte nye handlingsformer i spil, nye problemløsningsrelationer, og selvfølgelig også muligheden for, at de studerende på baggrund af egen aktivitet udvikler ny, teoretisk viden. For så vidt er dette alt sammen ikke forskelligt fra, hvad der "normalt" sker i projektarbejdet på RUC, men formen har været en ganske anden, hvor langt flere studerende er kommet i faglig og social kontakt med hinanden.

En særlig opmærksomhed var der på eksamen, hvor en synopsis, der var individuelt produceret, kom til at udgøre rammen. Synopsens omfang blev fastlagt til to sider.

De studerende var altså ansvarlige for hele antologien, den var pensum for de studerendes eksamen, men eksamen blev sporet af den individuelle synopsis. De studerende var i forhold til den individuelle synopsis ikke bundet af deres egen case i antologien, de kunne vælge deres temaer i synopsen frit i forhold til det genstandsfelt, der blev behandlet i antologien. Antologien udgjorde rammen for eksaminationen og synopsen udgjorde retningen. ${ }^{1}$

\footnotetext{
${ }^{1}$ Lærerkollegiet har oplyst til de studerende at antologien vil blive vurderet ud fra følgende kriterier og parametre: "Arbejdets omfang, selvstændighedsgraden af arbejdet, originaliteten i arbejdet, de læringsprocesser der kommer til udtryk gennem arbejdet samt kvaliteten af anvendelsen af metodiske og teoretiske perspektiver. Der er ligeledes krav til at klyngen deltager i midtvejsseminaret og fremlægger perspektiver fra emnearbejdet ved evalueringsseminaret." Såvel midtvejsevalueringen som evalueringsseminaret er former for udviklingsdimensioner i projektarbejdet på RUC. Det findes ikke alle steder, men det eksisterer bl.a. ved Arbejdslivsstudier. I begge tilfælde arbejder studerende og vejledere sammen om at kritisere, udvikle og perspektivere studenternes arbejde i løbet af den samlede projektfase.
} 
I evalueringen påpegede de studerende, at usikkerheden omkring denne synopsis og dens indhold var for stort. Den sidemæssige begrænsning besværliggjorde udarbejdelsen af synopsen, og det var vanskeligt for de studerende at finde ud af, hvad vejleder og censor forventede af synopsen. Men resultatet blev godt modtaget af både vejledere og censorer, og karaktererne lå i den absolut høje ende: 20 studerende fik 12, 24 studerende fik 10 og 8 studerende fik karakteren 7.

\section{Antologieksperimentet og aktionsforskning}

Man kan argumentere for, at en væsentlig linje i eksperimentet er rettet mod aktionsforskningen. Der blev i det ene af kurserne, som var tilknyttet eksperimentet, lagt vægt på aktionsforskning, og der kan trækkes linjer til aktionsforskningens grundlag, når projektet anskues ud fra de studerendes synspunkt. Her spiller Donald Schöns begreb om den reflekterende praktiker en væsentlig rolle - både i forhold til de studerendes refleksion $i$ handling og i forhold til de studerendes refleksion over handling. Hvad angår refleksion $i$ handling hedder det hos Schön:

"Vores viden ligger som regel indbygget $\mathrm{i}$ vores handlemønstre og i vores fornemmelse for den materie, vi har med at gøre. Det forekommer korrekt at sige, at vores viden ligger i vores handlinger". (Schön, 2001: 51).

For Schön og for Antologieksperimentet bliver det herefter centralt at reflektere over disse handlinger, altså skabe refleksion ikke bare $i$ handling men også over handling. Det er bl.a. i den forbindelse - stadig set fra de studerendes synspunkt - at der kan tales om aktionsforskning og aktionsorientering, især hvis argumentationen hæftes på Wilfred Carrs og Stephen Kemmis' definition på aktionsforskning fra midten af 1980'erne:

\footnotetext{
"Aktionsforskning er ganske enkelt en form for selvreflekterende undersøgelse, foretaget af deltagerne i sociale relationer for at forbedre rationaliteten og berettigelsen af deres egen praksis, deres forståelse af denne praksis og de situationer, hvori praksis udføres". (Carr og Kemmis, 1985: 162).
}

Samlet set må det understreges at der med hele konstruktionen blev skabt en række nye relationer mellem den enkelte studerende, klyngen af studerende og vejlederne. Man kan også sige, at relationerne mellem den enkelte og fællesskaberne blev udvidet og udviklet med fokus på at udvide og udvikle projektarbejdsformen på RUC. Hovedparten af de studerende gjorde i evalueringen opmærksom på, at såvel det faglige som det sociale udbytte af "Antologiprojektet" havde været større end ved det gængse og enkeltstående projektforløb på RUC. 


\section{Nogle udfordringer i projektet}

Projektet/eksperimentet har selvfølgelig ikke været uden problemer og udfordringer, men generelt har der blandt de studerende været en grundlæggende tilfredshed med forløbet. $82 \%$ anfører således, at de mener projektet bør fortsætte i de kommende semestre. De fleste mente, det havde været spændende, men der er også en række udfordringer til fremtiden. De studerende syntes at:

Vejlederrollen burde nydefineres og i høj grad ekspliciteres, fordi projektet bryder med den traditionelle vejlederrolle på RUC, hvor en enkelt vejleder er tilknyttet en enkelt projektgruppe. Det har ikke været tilfældet i dette forløb, hvor en vejleder har været tilknyttet en klynge og dermed har skullet vejlede både i forhold til klyngen og i forhold til casegrupperne. Det giver en række udfordringer, som der i fremtiden skal arbejdes med. De studerende påpeger i evalueringen, at der bør være mere fokus på det faglige og det skrevne. De mener vejledernes rolle i den fælles klyngevejledning i højere grad bør være som vidensudvikler. Altså: Vejlederne skal i højere grad være i stand til at komme med inspirerende fælles indspil til faglig udvikling f.eks. gennem forelæsninger af mere almen karakter og gennem forskellige former for workshops og temaseminarer. Man kunne også sige, at vejlederne i den forbindelse i højere grad skal være ressourcepersoner. Ekspliciteringen af alt dette skal ske meget tidligt i forløbet.

Linjerne mellem den enkelte og det fxlles har fået nye rammer, og dette burde tydeliggøres for de studerende meget tidligt i projektforløbet. Det er vigtigt, at dette videreformidles til kommende forløb af lignende karakter. Altså: Relationerne mellem den enkelte, det fælles og eksamen har fået nye rammesætninger, og dette skal ekspliciteres. Det samme gælder relationerne mellem vejlederne: F.eks. ville det ifølge de studerende være en god idé, at vejlederne er afklarede på fælles forventninger til de enkelte dele i "Antologiprojektet".

Kompetencer: De studerende er stort set enige om, at projektet har givet dem gode kompetencer i bredden. De mener samtidig, at det er en fremtidig udfordring også at komme mere i dybden. Altså skal der arbejdes mere intensivt med relationerne mellem processen i projektet og den faglige dybde.

Kritiske kommentarer og diskussioner af projektet kunne godt have fået mere plads i eksperimentet.

Mange studerende har savnet dette. Der kan i den forbindelse henvises til Etienne Wenger, som ser praksisfællesskaber som udspændt mellem gensidigt engagement, fælles virksomhed og fælles repertoire. Det skal understreges, at ingen af delene hverken hos Wenger, i virkeligheden eller i det gennemførte projekt/eksperiment er 
ukomplicerede. Tværtimod er det en realitet, at et praksisfællesskab hverken er "en havn af samhørighed eller en $\varnothing$ af fortrolighed isoleret fra politiske og sociale relationer. Uoverensstemmelse, udfordringer og konkurrence kan være måder at deltage på. Som deltagelsesform afslører oprør ofte et større engagement end passiv konformitet". (Wenger, 2004: 94).

Det betyder i al sin enkelthed, at den kritik, som udvikles gennem et eksperiment, bør have stemme, vægt og gennemslag, fordi udfordringerne i denne sammenhæng får liv og får lov til at leve. Det er centralt at lytte til dette.

Hertil kommer, at flere studerende synes, at der har været et for voldsomt empiripres i eksperimentet. Dette er dog ikke en kritik af eksperimentet som sådant - snarere af studieordningen.

Som afrunding og delvis rammesætning omkring en udvikling af antologieksperimentet ved RUC et citat af Wenger, og en udtalelse fra en af de studerende, der indgik i "Antologiprojektet", samt en samlende pointe fra en af censorerne ved eksamen:

"Da gensidigt engagement ikke kræver homogenitet, er en fælles virksomhed ikke ensbetydende med enighed i umiddelbar forstand. I visse fællesskaber kan uenighed ligefrem blive opfattet som en produktiv del af virksomheden. Virksomheden er ikke fælles i den forstand, at alle mener det samme eller er enige om alting, men ved, at den er forhandlet i fællesskab". (Wenger, 2004: 96).

"Vi har arbejdet ud fra et fælles emne, og derfor har arbejdet i casen været retningsbestemt - ikke af en problemformulering som normalt, men af det bredere tema. Det har været en lettelse og sparet os tid. Herudover gør sammensætningen af de forskellige cases i en samlet antologi, at vi kan diskutere vores stof på en meget dybere måde, og vores arbejde føles mere samfundsrelevant end hvis, vi havde beskæftiget os med en enkelt case". (En studerendes kommentar i spørgeskemaundersøgelsen).

"De har bearbejdet materialet på tværs af cases og fået en bredere forståelse af temaet, fordi de kunne tage udgangspunkt i fire cases empiri, der var forskellige. De kunne se flere metoder og teorier i brug ud over dem, de selv havde anvendt og gøre sig overvejelser over, hvad andre teorier og metoder kunne have bragt deres case. De har kunnet opsamle og lave fælles konklusioner på tværgående emner". (En censors kommentar i spørgeskemaundersøgelsen). 
Som allerede anført mente mere end $80 \%$ af de studerende, at "Antologieksperimentet" havde været en positiv oplevelse, og at det burde føres videre i de kommende semestre. Det er efterfølgende blevet vedtaget i studienævnet, at "Antologiformen" nu er den form, undervisningen ved K1-modulet ved Arbejdslivsstudier udspændes omkring.

Søren Dupont: 58 år, ph.d. i Idéhistorie og cand.mag. i Kulturarbejde og -formidling. Har i mere end 30 år arbejdet ved forskellige universiteter, de sidste 15 år som lektor ved RUC $i$ PAES. Søren Dupont og Cxcilie Saul har senest publiceret bogen Hvorfor RUC? - Derfor RUC!, som kan hentes via UniPæds hjemmeside under "Publikationer". Brug følgende link:

http://www.ruc.dk/fileadmin/assets/paes/Unipaed/Hvorfor_RUC_derfor_RUC_2011.pdf

Søren Dupont arbejder i øjeblikket på en publikation omhandlende pædagogik og frnomenologi.

\section{Litteratur}

Andersen, H. L..(2010). "'Constructive alignment' og risikoen for en forsimplende Universitetspædagogik". Dansk Universitetspædagogisk Tidsskrift, nr. 9. København.

Carr, W., \& Kemmis, S. (1985). Becoming Critical: Education, Knowledge and Action Research. London: Falmer Press.

Saul, C., Larsen, T. A., \& Dupont, S. (2011). Evaluering af Antologieksperimentet ved Arbejdslivsstudier. En alternativ projektarbejdsform på RUC. Roskilde Universitet. Roskilde. Tilgængelig på http://www.ruc.dk/fileadmin/assets/paes/Unipaed/Evaluering af Antologieks perimentet paa Arbejdslivsstudier.pdf

Wenger E. (2004). Praksisfallesskaber. Læring, mening og identitet. København: Hans Reitzels Forlag.

Wulf-Andersen, T., Gitz-Johansen, T., \& Rasmussen, K. (2007). "Undervisning i klynger: En artikel om erfaringer med at organisere en form for undervisning, der skaber forbindelse mellem projektarbejde og bredere faglige temaer", Dansk Pædagogisk Tidsskrift, 4. København. 


\title{
Kortere studietider - krav og konsekvenser
}

\author{
Palle Rasmussen, professor, Institut for Laring og Filosofi, \\ Aalborg Universitet.
}

De lange studietider ved universitetsuddannelserne er et tilbagekommende tema i uddannelsespolitikken. I begge de store samfundsøkonomiske planer, som den daværende regering og opposition fremlagde i 2010, foreslås tiltag til afkortning af studietiderne. Men faktisk er der i de seneste år blevet indfort en række tiltag, herunder stramme rammer for specialeskrivningen og frrdiggørelsesbonus. Virkningerne af disse tiltag kendes endnu ikke. Det gxlder også mulige utilsigtede konsekvenser, som for eksempel underminering af de studerendes faglige kompetencer og marginalisering af studerende med svagere forudsætninger og netværk. I artiklen argumenteres der for, at det $i$ denne situation vil være uforsvarligt at indføre yderligere foranstaltninger til forkortelse af studietiderne.

\section{Studietider i de samfundsøkonomiske planer}

Lange studietider ved universitetsuddannelserne har gennem lang tid været et uddannelsespolitisk tema, som dukkede op med jævne mellemrum. Inden for de seneste år er der dog kommet stærkere politisk fokus på spørgsmålet. I 2010 fremkom to store planer for at sikre det danske samfund og dets økonomiske grundlag i de kommende år, Danmark 2020, som er fremlagt af den daværende regering bestående af Venstre og Konservative, og Fair Løsning, som er fremlagt af Socialdemokratiet og SF. Uddannelse står centralt i begge planer, og begge foreslår også tiltag til at afkorte studietiderne.

I Danmark 2020, som Regeringen fremlagde i foråret 2010, opstilles ti mål for det danske samfund af 2020. To af disse mål handler klart om uddannelse, nemlig at danske skolebørn skal være blandt de dygtigste i verden (nr. 3), og at mindst et dansk universitet skal være blandt Europas top 10 (nr. 4). De videregående uddannelser indgår imidlertid også under målet om, at det danske arbejdsudbud skal være blandt de 10 højeste i verden (nr. 2). Til at opnå dette mål opregnes en række initiativer, blandt andet tidligere færdiggørelse af uddannelser. Det uddybes således:

"Regeringen vil vurdere mulighederne for at justere SU-systemet, så de studerende tilskyndes til at færdiggøre deres uddannelser tidligere. Regeringen vil samtidig evaluere de foreløbige erfaringer med den nye ordning, hvor der 
beregnes en forhøjet karakter fra den adgangsgivende eksamen, når videregående uddannelse påbegyndes inden for to år fra den adgangsgivende eksamen." (Regeringen, 2010, s. 17).

Dette initiativ blev konkretiseret i et regeringsudspil i efteråret 2010 (Regeringen, 2010a), som indebar fjernelse af SU for hjemmeboende unge på ungdomsuddannelserne (de såkaldte "cafepenge"), begrænsning af SU til uddannelsernes normerede tid, bonus til unge som påbegynder uddannelse og færdiggør på under normeret tid, samt fremrykning af 1,08-reglen til at gælde unge, som påbegynder videregående uddannelse inden for et år efter afslutningen af den adgangsgivende uddannelse. Regeringen forventer, at gennemførelse af udspillet vil øge udbuddet af arbejdskraft med ca. 4.000 personer og styrke de offentlige finanser med cirka 1 milliard kroner. Heraf vil besparelser på SU-udgifterne udgøre 250 millioner, mens de resterende 750 millioner vil være resultat af, at de studerende kommer hurtigere ud på arbejdsmarkedet.

Planen Fair Løsning blev oprindeligt fremlagt af Socialdemokratiet og SF i sommeren 2010. Et år senere fremkom der en ny udgave, som var revideret og udbygget som reaktion på debatten om den oprindelige plan samt regeringens 2020-plan. Også i Fair Løsning står uddannelse centralt. I den oprindelige udgave var der opstillet fem initiativer, og et af dem hed "Mere og hurtigere uddannelse" (Socialdemokratiet \& SF 2010, s. 7). Her blev der opstillet et mål om, at danske unge skulle gennemføre en kompetencegivende uddannelse et halvt år tidligere i gennemsnit. I den reviderede udgave af planen er strukturen lidt anderledes, men hurtigere gennemførelse af uddannelse er stadig et væsentligt element. I afsnittet om uddannelsespolitik hedder det: "Socialdemokraterne og SF har et mål om, at unge skal et halvt år hurtigere igennem deres uddannelse", og der henvises blandt andet til følgende konkrete initiativer for at nå dette mål: Omlægning af optagelsessystemet, så det bliver lettere at blive optaget på drømmeuddannelsen, hvis man starter lige efter endt ungdomsuddannelse; fremrykning af 1,08-modellen fra 2 til 1 år; fjerne barrierer for hurtigere gennemførelse, fx ved at have optag flere gange årligt samt afskaffe værnepligten; kontant bonus ved færdiggørelse af kandidatuddannelse på normeret tid; bedre tilrettelæggelse af videregående uddannelser, så den studerende kan lære mere på samme tid, fx ved at have tre semestre på et år eller et "hurtigt spor" (Socialdemokratiet \& SF, 2011, s. 66).

Realiseringen af målet om at få de unge hurtigere igennem uddannelsessystemet forventes at give en samfundsøkonomisk gevinst på 2,3 mia. kr. 
Som bekendt skiftede den parlamentariske magtbalance ved folketingsvalget i september 2011. Den nye regering, som i skrivende stund endnu ikke er dannet, vil hvile på et skrøbeligt flertal og få store vanskeligheder ved at realisere Fair Løsning. I forhold til spørgsmålet om studietider ved universitetsuddannelserne har det næppe den store betydning; for som det fremgår, er der en høj grad af overensstemmelse mellem de to parlamentariske blokke på dette område. Den væsentligste forskel er, at planen fra $\mathrm{S}$ og SF er mere ambitiøs med målet om at nedbringe studietiderne med et halvt år i gennemsnit.

\section{Konkurrencestatens økonomiske rationaler}

De samfundsøkonomiske planer og deres uddannelsespolitiske forslag må ses i sammenhæng med den tendens i dansk politik, som er blevet kaldt en udvikling mod konkurrencestaten (Pedersen, 2011). Det er i høj grad en reaktion på de sidste par årtiers stigende globalisering og kom blandt andet til udtryk i Globaliseringsrådets arbejde i årene 2005-2006. Her formulerede en samling af stærke politiske og økonomiske aktører det synspunkt, at den intensiverede globale konkurrence kræver omstillinger af det danske velfærdssamfund med henblik på at sikre både institutionernes og individernes bidrag til at fremme vækst og velstand. Konkurrencestatens politik går ud på at styrke nationens institutionelle konkurrenceevne, blandt andet ved at opbygge stærke samspil mellem offentlige og private institutioner, men især ved at sørge for, at samfundsmedlemmerne er mest muligt effektive, produktive og innovative. Derfor kommer uddannelse til at stå centralt, men på en ny måde. I den tidligere velfærdspolitik, som var udviklet siden 1930'erne med Socialdemokratiet som ledende kraft, blev uddannelse set som et velfærdsgode, som flest muligt borgere skulle have ret til og kunne bruge til at forbedre deres levestandard og livskvalitet. I konkurrencestatens politik er velfærdsrettighederne vel ikke forladt, men de er suppleret med en forpligtelse til at bruge uddannelsesmulighederne produktivt og effektivt, således at uddannelsesinvesteringerne bidrager mest muligt til den nationale konkurrenceevne, som skal give mulighed for velfærd. Der sker således en delvis forskydning fra ret til pligt i borgernes adgang til uddannelse.

I begge de samfundsøkonomiske planer betragtes uddannelse ud fra to økonomiske logikker:

På den ene side ses uddannelse, især videregående uddannelse, som en samfundsmæssig investering. Sammenligner man personer med og uden uddannelse, har de uddannede stærkere tilknytning til arbejdsmarkedet og er mere produktive. Og uddannelsens positive økonomiske virkning er stærkest for personer med videregående uddannelse. Videregående uddannelser med godt og relevant fagligt indhold gør de uddannede mere vidende, fleksible og innovative, og derfor kan de medvirke til at 
forbedre det danske samfunds konkurrenceevne (Lundvall, 2001; Junge \& Skaksen, 2010).

På den anden side indebærer selve uddannelsestiden omkostninger for det offentlige. De studerende forbruger offentlige uddannelsesressourcer, deres leveomkostninger dækkes overvejende af staten via SU-systemet, de indgår ikke meget i arbejdsudbuddet, og de bidrager i minimalt omfang til statens skatteindtægt.

Begge disse logikker er reelle, og de politiske planer må tage højde for dem. Men den måde, hvorpå begge politiske blokke går til spørgsmålet om studietider, er af flere grunde problematisk.

Der indgår tilsyneladende ikke overvejelser om de potentielle modsætninger mellem de to logikker. Hvis rammerne for universitetsuddannelserne strammes for meget af hensyn til at begrænse samfundets direkte omkostninger, kan uddannelserne ikke nødvendigvis blive ved med at give de uddannede den viden, de færdigheder og de kompetencer, der sikrer de uddannedes positive bidrag til konkurrenceevnen. Hvor grænsen går, er svært at sige, og universitetsuddannelserne har ofte vist sig at kunne opretholde høj uddannelseskvalitet under vanskelige vilkår. Men at forkorte studietiderne med gennemsnitligt et halvt år, som oppositionen lægger op til, vil kræve stærke indgreb i rammerne.

Et af de forhold, som kravet om at begrænse studietiderne ikke tager højde for, er de studerendes tilknytning til og overgang til arbejdsmarkedet. Ligesom studerende andre steder i verden supplerer danske universitetsstuderende deres indkomst med erhvervsarbejde i fritiden. En del af dette arbejde er ufaglært, ofte i servicesektoren. En anden del rummer arbejdsopgaver, som kan have indholdsmæssig relevans for de studerendes uddannelse, for eksempel hvis de arbejder som medhjælp i vidensorganisationer eller virksomheder. For mange studerende giver dette studierelevante erhvervsarbejde både kompetencer og netværk, som kan sikre dem jobs efter endt uddannelse. Det er en velkendt mekanisme, som bl.a. blev bekræftet for nogle år siden i en undersøgelse initieret af Videnskabsministeriet (Ministeriet for Videnskab, Teknologi og Udvikling 2005). Videnskabsminister Helge Sander udtalte dengang: "At få brugt sin viden i praksis og knytte kontakter i relevante erhvervsmiljøer er motiverende og skaber god sammenhæng mellem studierne og de fremtidige beskæftigelsesmuligheder". (Pressemeddelelse, 5. januar 2005). Men presset for at begrænse studietiden kan gøre det sværere for studerende at fastholde det studierelevante erhvervsarbejde. Det gælder ikke mindst i uddannelsens afsluttende fase, hvor rammerne for specialeskrivningen vil tvinge de fleste studerende til at nedprioritere erhvervsarbejdet, selv om det måske kunne give adgang til job efter eksamen. 
De tiltag, der foreslås i de samfundsøkonomiske planer, har alt for lidt sammenhæng med virkeligheden i uddannelserne og på arbejdsmarkedet. Sådanne indgreb er der allerede kommet en del af de senere år, og deres virkninger er vanskelige at overskue.

\section{ÆEndringer i rammerne for studieforløb}

I de senere år er der blevet gennemført en række ændringer i rammerne for universitetsuddannelserne med henblik på at effektivisere studieforløbene. Jeg vil især fremhæve følgende: Med velfærdsaftalen fra 2006, som blev tiltrådt af et bredt flertal i Folketinget, blev fortrinsretsordningen (1,08-ordningen) indført. Ordningen betyder, at ansøgere til de videregående uddannelser siden optaget 2009 har fået deres adgangskvotient forhøjet med en faktor pa 1,08, hvis de søgte ind inden for to år efter den adgangsgivende eksamen. Formålet med 1,08-ordningen er at tilskynde de unge til at påbegynde en videregående uddannelse hurtigere efter den adgangsgivende eksamen.

Året før, i 2005, var kvote 2 ved optaget til universitetsuddannelsernes blevet omlagt som led i revision af adgangsbekendtgørelsen i 2005. Ud fra den vurdering, at for mange unge brugte lang tid på at samle point til kvote 2, blev kvoten gjort mindre, så der som hovedregel optages 10 procent via kvote 2 og 90 procent via kvote 1 på universitetsuddannelserne.

Velfærdsaftalen fra 2006 indførte også bindende tidsbegrænsninger for kandidatspecialer. Historisk har studerende ofte brugt mere end det normerede halve år på specialet, og formålet med den nye ordning var at fjerne denne årsag til studietidsforlængelser. Ordningen betyder, at den studerende bruger et eksamensforsøg, hvis specialet ikke afleveres inden for den aftalte tidsfrist på normalt et halvt år. Der aftales en ny opgaveformulering, der skal ligge inden for samme emneområde med en afleveringsfrist på tre måneder, og den studerende bruger det næste eksamensforsøg, hvis der heller ikke i denne omgang afleveres.

I 2009 blev der indført færdiggørelsesbonus ved universiteternes kandidatuddannelser. Bonus udløses til det enkelte universitet for studerende, som gennemfører kandidatuddannelsen inden for normeret tid plus tre måneder. Det samlede beløb til færdiggørelsesbonus er et fast beløb, der fordeles mellem universiteterne forholdsmæssigt efter antallet af rettidige afsluttere.

Det er svært at vurdere, hvilke virkninger disse tiltag har haft. Data om optaget til de videregående uddannelse i 2010 pegede ikke på nogen tydelig virkning af 1,08 bonusordningen; de nyoptagne studerende er blevet yngre, men det fortsætter blot en 
udvikling, som har været i gang de sidste 10 år (Politiken, 4. august 2010; "Karakterbonus har begrænset effekt"). Ordningen med tidsbegrænsning for universitetsspecialer har eksisteret så længe, at virkninger burde kunne spores, men eksisterende statistik (Undervisnings- og Bygningsstyrelsen, 2011) giver ikke mulighed for det.

Oplysninger om hvor mange afsluttende studerende, som hvert år udløser færdiggørelsesbonus, er tilgængelige. Ordningen har kun eksisteret $i$ to år, og som forventeligt viser tallene ikke nogen forandring i denne korte periode. I 2010 var det 36 pct. af de afsluttende kandidater, som udløste bonus. Dette dækker dog over store forskelle mellem hovedområder og institutioner. Inden for Humaniora var andelen af bonuskandidater 21 pct. mens den inden for Sundhedsvidenskab var 57 pct. Færdiggørelsesbonus forstærker altså de eksisterende skævheder i tildelingen af ressourcer til hovedområderne. Der er også stor forskel mellem universiteterne: Ved Københavns Universitet var andelen af humanistiske bonuskandidater 9 pct., mens den ved Aalborg Universitet var 64 pct. (beregnet efter oplysninger i Universiteternes Statistiske Beredskab, ark F, Danske Universiteters hjemmeside).

Ud fra min erfaring fra uddannelserne ved Aalborg Universitet kan jeg imidlertid nævne nogle eksempler på uheldige eller uhensigtsmæssige konsekvenser af de indførte tiltag.

Ved en række uddannelser er der tradition for, at specialestudiet afsluttes med en mundtlig eksamen på grundlag af den afleverede specialerapport. Det gælder blandt andet uddannelserne ved Aalborg Universitet. Der er mange gode argumenter for denne form for specialeeksamen: Den giver mulighed for at efterprøve den studerendes viden og evne til at argumentere, den fremmer mere alsidige kompetencer, og den udgør en mere meningsfuld afslutning af mange års studium en blot det at modtage en karakter med posten. Men når nu specialestudiet kun må tage et halvt år, kan det blive et problem, at der efter afleveringen af rapporten skal gå et par uger, mens censor og eksaminator læser produktet og forbereder eksamen. På Humaniora ved Aalborg Universitet har der på denne baggrund for nyligt været taget initiativ til at indføre mulighed for, at studerende kan fravælge den mundtlige del af specialeeksamen. Det illustrerer, hvordan stramningen af rammerne for specialet kan føre til fravalg af en pædagogisk ønskelig eksamensform.

Et andet eksempel gælder forholdet mellem orlov og færdiggørelsesbonus. Studerende har ret til at tage orlov fra studiet. Mulighederne er godt nok begrænsede: Man skal have bestået første semester på kandidatuddannelsen, og man må ikke have påbegyndt specialet. Orlov indebærer også, at man økonomisk skal klare sig selv: Man kan ikke få SU og heller ikke sociale ydelser. Men muligheden for orlov er der 
dog, og den kan være nyttig. Den kan for eksempel giver lejlighed til at komme lidt til hægterne efter dødsfald i den nærmeste familie eller andre krisesituationer. Eller den kan bruges til, at man i en periode kan koncentrere sig om et erhvervsarbejde, som man måske kan fastholde efter specialet. Orlov er ikke altid velbegrundet, men den kan være nødvendig og relevant for studerende og deres videre karriere.

Man skulle tro, at retten til orlov havde konsekvenser for opgørelsen af færdiggørelsesbonus. Hvis studerende har orlov i nogle måneder (og dermed hverken bruger undervisningsressourcer eller SU), kan det vel ikke tælle med i studietiden. Men det gør det: Videnskabsministeriets krav til universiteternes indberetning af studietider (de såkaldte myndighedskrav) præciserer, at den eneste form for orlov, som ikke tæller med i studietiden, er barselsorlov. Så hvis man som uddannelsesleder eller lærer ved en universitetsuddannelse gerne vil opretholde uddannelsens økonomiske grundlag, må man altså af alle kræfter søge at forhindre studerende i at bruge deres ret til orlov, uanset hvor gode personlige eller faglige grunde de kan have.

\section{Konsekvenser for studerende og lærere}

De gennemførte foranstaltninger til at afkorte studietiderne og de uddannelsespolitiske diskurser, som knytter sig til dem, må påvirke de studerendes forhold til deres uddannelse og studieaktiviteter. De skaber et øget pres for, at de studerende skal udøve strategisk og effektiv planlægning af deres studieadfærd. Det kan lyde rimeligt nok, men reelt er det svært.

Det centrale i den læring, som foregår inden for universitetsstudier, er studerendes selvstændige tilegnelse af evnen til at tilgå og fordybe sig i faglig viden og at bearbejde, supplere og forny denne viden (Bowden \& Marton, 1998). Det er grundlæggende den samme læring, som sker i forskning. Den centrale pointe ved forskningsbaseret undervisning er ikke i sig selv det forhold, at lærerne også er forskere, men at de studerende undervises og arbejder i et læringsmiljø, hvor faglig erkendelse og fordybelse er til stede på mange forskellige måder. I denne forstand er læringen også en socialisering ind i en organiseret faglighed (Rasmussen, 2005). Læring i universitetsstudier bygger på faglig interesse; de studerende må have tilstrækkelig interesse for uddannelsens fag og problemstillinger til at kunne engagere sig i det selvstændige arbejde med faget. For langt de fleste studerende på kandidatuddannelser er denne interesse også til stede efter, at de har valgt fag og gradvis specialiseret sig. Men læringen er en åben proces, hvor man må afprøve forskellige muligheder, og hvor nogle af dem kan vise sig at være vildspor eller at kræve mere arbejde og længere tid, end man havde forudset. En af de studieaktiviteter, hvor dette ofte viser sig, er praksisprojekter, hvor de studerende $i$ en periode medvirker eller undersøger $i$ en sammenhæng uden for universitetet, som de ikke kender på forhånd. En anden er 
internationale studie- eller praktikophold. En tredje er specialeskrivningen. Både for disse aktiviteter og for andre gælder det, at netop det at have afprøvet forskellige muligheder ofte vil styrke det faglige udbytte og dermed kandidaternes kompetence.

Hvis kravet om at planlægge sin studieadfærd strategisk og effektivt bliver for stærkt, kan det betyde, at studerende søger at styre uden om studieaktiviteter, hvor kravene til indsats og tidsanvendelse er mindre forudsigelige. Det underminerer potentielt de særlige kvaliteter, som ligger i den interessebaserede, selvstændige læring.

Men konsekvensen kan også være, at de studerende ikke kan leve op til kravet om planlægning af studieadfærden og dermed marginaliseres. Det gælder nok især studerende med færre ressourcer og begrænset daglig kontakt med studiemiljøet. Jeg har set flere eksempler på specialestuderende, som på grund af manglende overblik og andre omstændigheder - for eksempel et erhvervsarbejde, som de ville kunne fortsætte med efter endt uddannelse - pludselig har brugt deres tredje eksamensforsøg og står i en overhængende risiko for ikke at kunne afslutte deres kandidatuddannelse.

Som nævnt foreligger der, så vidt jeg ved, ikke bredere undersøgelser af konsekvenserne af de rammer for specialet, som blev indført med Velfærdsaftalen af 2006. Der er gennemført en undersøgelse af specialestuderende ved Statskundskab på Københavns Universitet, hvis hovedresultat er, at de fleste studerende er tilfredse med tidsbegrænsningen, og at karakterniveauet ikke er faldet (Jensen \& Jensen 2011). Mine egne erfaringer og informationer fra kolleger peger også på, at aftalen for mange studerende har ført til en mere overkommelig og dermed tilfredsstillende afslutning på uddannelsesforløbet. Men jeg tror også, at en del studerende er blevet sat i unødigt svære situationer og måske har måttet opgive at afslutte uddannelsen.

For universiteternes lærere betyder det politiske fokus på kortere studietider, at de via mål, eksamenskrav, pensum og stofgennemgang skal tilbyde de studerende mest mulig sikkerhed for, at de kan gennemføre til tiden. Det kræver både universiteternes ledelser og de studerende.

Også for lærerne er der en balance, som skal findes. Der bør selvsagt være klare mål og rammer for universiteternes uddannelser, og det er et fremskridt at universiteterne i dag som regel beskriver disse mål og rammer i overskuelig og offentligt tilgængelig form. Men hvis forventningerne om studieforløb til tiden bliver for stærke, risikerer universitetspædagogikken at blive mindre orienteret mod de studerendes selv- 
stændige faglige læring og i stedet mere orienteret mod effektivitet i de studerendes adfærd.

\section{Afslutning}

Uddannelsespolitikken må tage højde for begge de økonomiske logikker, som gælder for de videregående uddannelser, både uddannelsernes bidrag til konkurrenceevne og velstand og uddannelsernes omkostninger på statsbudgettet. Men jeg finder det skræmmende, at både regering og opposition i deres økonomiske planer lægger så stærk vægt på yderligere afkortning af studietiderne uden at overveje eller søge at skaffe sig viden om konsekvenserne af de allerede gennemførte tiltag. Jeg ser det som udtryk for, at diskurserne om de lange studietider har fået lov til at leve deres eget liv i offentligheden og blandt de politiske beslutningstagere.

Jeg mener der er behov for tiltag og argumenter, som peger i en anden retning. Der er brug for analyser og indlæg, som kan fremme en mere alsidig og nuanceret økonomisk forståelse af universitetsuddannelserne. En forståelse, hvor uddannelsernes rolle ikke vurderes ud fra overordnede og naive økonomiske modeller, og hvor de økonomiske vurderinger forbindes med virkelighedens samspil mellem uddannelse, arbejde og konkurrenceevne.

Der er brug for institutionelle og pædagogiske tiltag, som kan bidrage til at opbygge studiemiljøer, der tager hånd om og understøtter studieforløbene. Det er et positivt alternativ til de disciplinerende foranstaltninger, som er indført de senere år, og som rummer stor risiko for utilsigtede virkninger. Der er også brug for praktik- og trainee-ordninger, som kan støtte de studerende i bestræbelserne for at skabe bedre kontakt med arbejdslivet frem gennem uddannelserne. Som led heri må skabes mere fleksible rammer for specialeskrivningen, som kan give de studerende mulighed for $\mathrm{i}$ uddannelsens afsluttende fase at opretholde en forankring i arbejdslivet. Noget af dette kræver ændringer i lovgivningen; men det er først og fremmest universiteternes eget ansvar at styrke studiemiljøerne og broerne til arbejdslivet.

Jeg har i artiklen peget på, at hverken tilsigtede eller utilsigtede virkninger af de senere års politiske initiativer til at nedbringe studietiderne er kendte. Det kunne begrunde et midlertidigt effektiviseringsstop i universitetspolitikken forstået som at træffe beslutning om, at der ikke fra politisk side indføres flere tiltag til afkortelse af studietiderne, før virkningerne af allerede indførte tiltag er kendt.

Palle Rasmussen er professor i uddannelses- og læringsforskning ved Institut for Læring og Filosofi, Aalborg Universitet. Han har forsket $i$ uddannelse og læring inden for forskellige dele af uddannelsessystemet og $i$ arbejdslivet. I forhold til universiteter og videregående uddannelser har han bl.a. arbejdet med uddannelsespolitik, kønsforskelle, evaluering og pædagogik. 


\section{Litteratur}

Bowden, J., \& Marton, F. (1998). The University of Learning. London: Routledge.

Jensen, H. N., \& Jensen, H. (2011) "Specialeskrivning på seks måneder". Dansk Universitetspædagogisk Tidsskrift, nr. 10, 2011, s 25-30.

Junge M., \& Skaksen, J. R. (2010). Produktivitet og videregående uddannelse. København: DEA.

Lundvall, B. (2001). "Universitetet i den lærende økonomi", in Maskell, P., \& Jensen, H. S. (red.) Universiteter for fremtiden - universiteterne og videnssamfundet. København: Rektorkollegiet.

Ministeriet for Videnskab, Teknologi og Udvikling (2005). Hovedresultater fra undersøgelsen om de studerendes erhvervsarbejde - og sammenhangen med frafald, studietid, startløn og beskæftigelse.

Pedersen, O. K. (2011). Konkurrencestaten. København: Hans Reitzel.

Rasmussen, P. (2005). "Læringens samfundsmæssighed", in Hermansen, M. (red.), Læring - en status. Århus: Klim.

Regeringen (2010). Danmark 2020. København: Statsministeriet.

Regeringen (2010a). SU, der skaber vækst og beskxftigelse. København: Undervisningsministeriet.

Socialdemokratiet \& SF (2010). En fair løsning - sammen ud af krisen.

Socialdemokratiet \& SF (2010). Fair løsning 2020 - sammen om Danmark.

Undervisnings- og Bygningsstyrelsen (2011). Notat om universiteternes bachelor- og kandidatuddannelser. 


\title{
Brugen af vejlederbrev til universitetsstuderende - en diskussion af dets betydning i vejledningsprocessen
}

\author{
Sussie Laustsen, adjunkt, ph.d., Institut for Klinisk Medicin og Afdeling \\ for Sygeplejevidenskab, Institut for Folkesundhed, Health, Aarhus \\ Universitet.
}

Gitte Wichmann-Hansen, lektor, ph.d., Center for Undervisningsudvikling og Digitale Medier, Arts, Aarhus Universitet.

Hanne Aagaard, adjunkt, ph.d., Afdeling for Sygeplejevidenskab, Institut for Folkesundhed, Health, Aarhus Universitet.

Golnosh Bahrami, adjunkt, ph.d., Institut for Odontologi, Health, Aarhus Universitet.

Pia Dreyer, adjunkt, ph.d. Afdeling for Sygeplejevidenskab, Institut for Folkesundhed, Health, Aarhus Universitet.

\section{Reviewet artikel}

\begin{abstract}
Siden 2008 har deltagere på Aarhus Universitets (AU) vejledningskurser udarbejdet individuelle vejlederbreve, som de kan anvende i vejledningsprocessen. I artiklen præsenteres en kvantitativ undersøgelse af hvor mange, der anvender vejlederbrevet. Endvidere diskuteres vejlederbrevets potentiale til at fremme relationen $i$ vejledningsprocessen, herunder om vejlederbrevet kan tydeliggøre sammenhænge mellem læringsmål, vurderingskriterier og studerendes læringsaktiviteter.
\end{abstract}

\section{Introduktion}

$\mathrm{AU}$ har igennem flere år satset på at kvalificere universitetsansattes pædagogiske kompetencer, herunder vejlederkompetencer. Der er gennemført kurser for VIPansatte om vejledning af universitetsstuderende fra BA til ph.d.-niveau. Siden 2008 har det været fast praksis, at deltagere på vejledningskurser udformer et vejlederbrev, som de får feedback på og drøfter i fællesskab med de øvrige deltagere. Fra 2010 er der på adjunktpædagogiske kurser indført et valgfrit vejledningsmodul (1 ECTS point), hvor udformning af vejlederbrev er obligatorisk. 
I vejlederbrevet skriver vejlederen, hvad han/hun tilbyder og forventer af den studerende. Vejlederbrevets funktion er at eksplicitere forventninger og praksisser af både institutionel og individuel art. Litteraturen anbefaler, at vejlederbreve anvendes i indledende fase af et vejledningsforløb som et redskab til forventningsstyring mellem den studerende og vejlederen (Rienecker et al. 2005). AU har valgt at følge denne anbefaling. Man har bevidst satset på at bevidstgøre vejledere om deres begrundede valg i egen vejledningspraksis ud fra ønsket om at forskningsbasere vejledningspraksis, at fremme studerendes læring, kvaliteten af specialer og afhandlinger, samt at forbedre studiemiljøet. Denne artikel baserer sig på en undersøgelse om brugen af vejlederbreve på $\mathrm{AU}$.

\section{Baggrund}

Vejlederbrev er en dansk terminologi primært udviklet af Rienecker og Stray Jørgensen (2005). I litteraturen refereres der ofte til contracts (Hockey 1996), mens andre taler om et memorandum of understanding eller blot a written understanding (Oxford Learning Institute: http://www.learning.ox.ac.uk/supervision/stages/expectations/). Andre forfattere taler om, at der udformes spørgsmål eller udsagn, som hhv. den studerede og vejlederen svarer på eller forholder sig til - fx ved brug af en såkaldt expectation scale (Moses, 1985).

Der er flere begrundelser for at udforme og anvende vejlederbreve. For det første kan vejlederbrevet ses som en mulig vej mod alignment, hvis man anlægger en konstruktivistisk vinkel herpå (Biggs \& Tang, 2007). Alignment har rødder i en konstruktivistisk grundantagelse om, at viden ikke overføres men skabes gennem den studerendes egne læringsaktiviteter og -arbejde. Derfor lægges der i denne tradition vægt på, at der i undervisningsplanlægning er sammenhæng mellem læringsmål, undervisningsaktiviteter og vurderingskriterier. Vejlederbrevet muliggør, allerede inden vejledningen påbegyndes, at trække alignment ind i vejledningsforløbet, idet væsentlige elementer i vejlederbrevet kan være at beskrive, hvordan vejleder vil hjælpe den studerende med at opnå sammenhæng mellem læringsmål og vurderingskriterier. Ydermere kan vejlederbrevet bruges til at eksplicitere forventninger til den studerendes læringsaktiviteter samt tydeliggøre ønsker om, at den studerende har en så aktiv og ansvarlig position i vejledningsrelationen som muligt.

For det andet er det fra uddannelsesforskningen kendt, at etablering og vedligeholdelse af relationer i vejledning kan vanskeliggøres af, at parterne har forskellige forventninger (Green \& Powell, 2005; Hockey, 1996; Kiley, 2003; Wright, 2003). Flere studier fremhæver, at vejledningsprocessen kan mislykkes, hvis den studerende har andre forventninger til vejledning end det, vejlederen tilbyder (Harboe, 2000; Holdaway, 1995). I forskningen om vejledning fremhæves, at der ofte er forskellige for- 
ventninger mellem studerende og vejleder. Studerende efterspørger proceskompetencer som fx tilgængelighed, venlighed, engagement, åbenhed, grundighed og struktur. Vejlederne lægger mere vægt på egne faglige kompetencer såsom viden, indsigt, håndværk, netværk og hjælp til finansiering (Woolhouse, 2002; Taylor \& Beasley, 2005). For at mindske denne uoverensstemmelse kan vejlederbrevet være midlet til målet, idet vejlederbrevet både tilbyder afstemning af forventninger og kan give relationen til den studerende legal opmærksomhed - en opmærksomhed der kan fremme studerendes aktive og ansvarlige arbejde med opgaven/projektet (Hockey, 1996; Kiley \& Mullins, 2008). I et review finder Wichmann-Hansen et al. 2007, at forventningsafstemning er essentiel for etablering og vedligeholdelse af vejledningsrelationen, idet uddannelsesforskning peger på, at vejledningsrelationen er afgørende for en vellykket vejledningsproces. Det fremhæves i reviewet, at forventningsafstemning mellem parterne er en forudsætning for at etablere og vedligeholde gode relationer i vejledningsforløbet samt for at skabe gunstige studiebetingelser for den studerende.

Tanken med vejlederbrevet er, at vejlederen og den studerende i fællesskab drøfter den kommende vejledningsproces ( $\mathrm{fx}$ mødeomfang, samarbejdsformer, deadlines, kontaktformer) og ikke mindst produktet (indhold, niveau, ambitioner, tekstfeedback, læringsmål og vurderingskriterier). Brevet skal ikke udleveres eller læses som et fastlåst og eviggyldigt tilbud, der fortæller den studerende: "Det her er, hvad du kan få" - Take it or leave it!" Brevet er et udspil; et oplæg til, at den studerende og vejlederen i fællesskab forhandler sig frem til en konsensus (Rienecker et al., 2005). Eksempelvis kan ambitioner og karakterniveau være konfliktfyldte emner, som nemt bliver tabuer i vejledningen, fordi de to parter har forskellige holdninger og forventninger til produktets kvalitet (Handal \& Lauvås, 2006). Vejlederbreve kan ses som en invitation til at drøfte emner - som et redskab til forhandling om noget, det kan være svært at få ud i det åbne.

Et vejlederbrev kan se forskelligt ud og kan anvendes på forskellig vis. Det kan udleveres inden første vejledning, ved første vejledning, lægges på nettet eller bruges som et baggrundsdokument for vejleder til vejledningsprocessen - dvs. at vejleder har brevet i tankerne under vejledning (Rienecker et al., 2005). AU har igennem en årrække satset på via universitetspædagogiske kurser at fremme brugen af vejlederbrevet (jf. Rienecker et al., 2005). Det er dog uklart, i hvilket omfang og hvordan vejlederbrevene anvendes. Endvidere savnes en diskussion af, om vejlederbrevet kan fremme alignment mellem læringsmål, vejledningsaktiviteter, vurderingskriterier og den studerendes læringsaktiviteter. Formålet med dette studie var at undersøge, $i$ hvilket omfang vejlederbrevet anvendes af vejledere, der har gennemgået kursus i 
brug af vejlederbrev på AU. Studiet blev drevet af interessen for at undersøge, om der er forskel på, hvor udbredt vejlederbreve er afhængigt af vejledernes fakultetsvise tilknytning. Studiet blev udformet, så det også i en vis grad kunne besvare, hvordan vejlederbrevene bruges, $\mathrm{fx}$. om de udleveres på skrift direkte til de studerende eller lægges på nettet, og til hvem brevene udleveres.

Studiet er primært designet til at give kvantitative svar på hoor mange og med hoilken fordeling. Resultaterne har givet anledning til en bredere diskussion af vejlederbrevenes formål og berettigelse. I artiklen diskuterer vi derfor resultaterne med den litteratur, som vejlederbreve skriver sig ind i, og vi rejser spørgsmålet, om vejlederbreve potentielt kan fremme studerendes forståelse af krav, egen rolle samt indflydelse på læring i vejledningsprocessen.

\section{Metode og materiale}

I et tværsnitsdesign blev der udsendt et elektronisk spørgeskema i perioden 20. april til 3. maj 2011. Spørgeskemaet bestod af tre spørgsmål: Tilknytning til fakultetsstruktur; hvilke studerende vejlederbrevet anvendes til; hvordan vejlederbrevet anvendes, herunder om man har det i tankerne, når man drøfter kommende vejledning med studerende, om det udleveres eller er tilgængelig på internettet. Endelig efterspørges en kort begrundelse, såfremt vejlederbrevet ikke anvendes.

Spørgeskemaet blev mailet til adjunkter, lektorer og professorer fra alle fire hovedområder Arts, Business and Social Sciences, Health og Science and Technology på AU, der havde deltaget i vejledningskurser i perioden 2008 til forår 2011. Deltagerne på vejledningskurser blev identificeret med e-mails via underviserne og kursussekretær. Besvarelse forgik anonymt. Der blev per mail udsendt én påmindelse om besvarelse. De indkomne data er primært analyseret med deskriptiv statistik. Efterfølgende diskuteres vejlederbrevets anvendelse i relation til vejledningspraksis, den studerendes forståelse af krav, egen rolle samt indflydelse på læring i vejlederprocessen.

\section{Resultater}

Spørgeskemaer blev mailet til 215 ansatte svarende til ca. 10\% af de VIP-ansatte på AU. 15 svarede, at de ikke havde deltaget i kurset, enten pga. sygdom eller fordi, de fejlagtigt stod på deltagerlisten. 128 af de resterende 200 responderede, dvs. svarprocenten var på $64 \%$.

Fordelingen af respondenterne var $9(7,0 \%)$ fra Arts, 51 (39,8\%) fra Business and Social Sciences, $32(25,0 \%)$ fra Health og $36(28,1 \%)$ fra Science and Technology.

Vi fandt, at 62 af de 128 (48,5\%; 95\% confidens interval (CI) 39,5-57,4\%) anvender vejlederbrevet. Fordelingen af de, der anvender vejlederbreve, var 6 (9,7\%) fra Arts, 
27 (43,5\%) fra Business and Social Sciences, 12 (19,4\%) fra Health og 17 (27,4\%) fra Science and Technology. Af de 66 respondenter, der ikke anvender vejlederbrev, svarede $15(22,7 \%)$, at de overvejer at benytte vejlederbrevet i fremtiden. 7 af de 66 $(10,6 \%)$ svarede, at de ikke havde fået nye studerende, siden de havde været på vejlederkursus og derfor ikke anvendte vejlederbrevet. I figur 1 vises den procentvise fordeling af de, der anvender, og de der ikke anvender vejlederbrev på de fire hovedområder på universitetet.

Figur 1. Prævalens af undervisere på Aarhus Universitets fire hovedområder, der i 2011 anvender deres vejlederbrev.

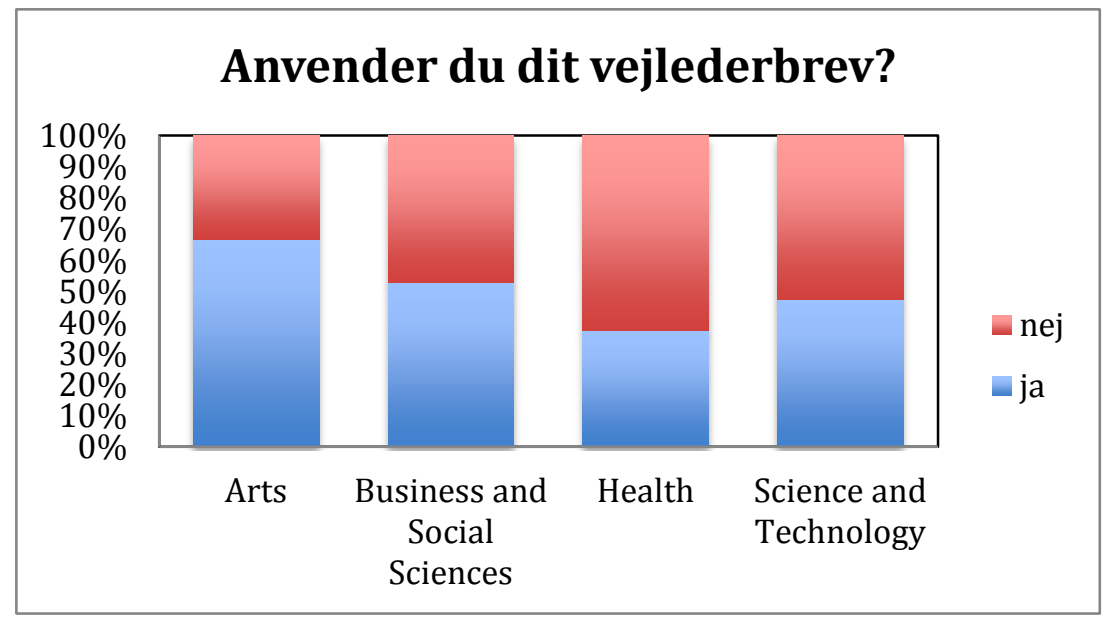

Af de 128 respondenter har 38 (29,7\%; 95\% CI; 21,8 - 37,6) vejlederbrevet i tankerne under vejledning, mens 35 (27,3\%; 95\% CI 19,6 - 35,1) udleverer vejlederbrevet til studerende, og $2(1,6 \%)$ har lagt deres vejlederbrev på internettet. I tabel 1 er vist, hvordan vejlederne indenfor de fire hovedområder anvender vejlederbrevet.

Tabel 1. Prævalens af undervisere på Aarhus Universitet, der i 2011 anvender deres vejlederbrev på tankeplan og udleverer vejlederbrevet.

\begin{tabular}{lcccc}
\hline & \multicolumn{2}{c}{ I tankerne } & \multicolumn{2}{c}{ Udleverer } \\
\cline { 2 - 5 } & Ja & Nej & Ja & Nej \\
& $n(\%)$ & $n(\%)$ & $n(\%)$ & $n(\%)$ \\
\hline Total $\mathrm{n}=128$ & $38(29,7)$ & $90(70,3)$ & $35(27,3)$ & $93(72,7)$ \\
Art $\mathrm{n}=9$ & $2(5,3)$ & $7(7,8)$ & $6(17,1)$ & $3(3,2)$ \\
Business and Social Sciences $\mathrm{n}=51$ & $19(50,0)$ & $32(35,6)$ & $15(42,9)$ & $36(38,7)$ \\
Health $\mathrm{n}=32$ & $9(23,6)$ & $23(25,6)$ & $5(14,3)$ & $27(29,0)$ \\
Science and Technology $\mathrm{n}=36$ & $8(21,1)$ & $28(31,1)$ & $9(25,7)$ & $27(29,0)$ \\
\hline
\end{tabular}


For alle fire hovedområder gælder, at vejlederbrevene anvendes både til ph.d.- og specialestuderende (figur 2). Elleve af de 62 (17,7\%) anvendte vejlederbrevet til begge typer studerende. Som det ses af Figur 2 anvendes vejlederbreve oftest på specialeniveau $\mathrm{p}=0,026$.

Figur 2. Prævalens af undervisere på Aarhus Universitets hovedområder der $i 2011$ anvender deres vejlederbrev til ph.d. - og specialestuderende.

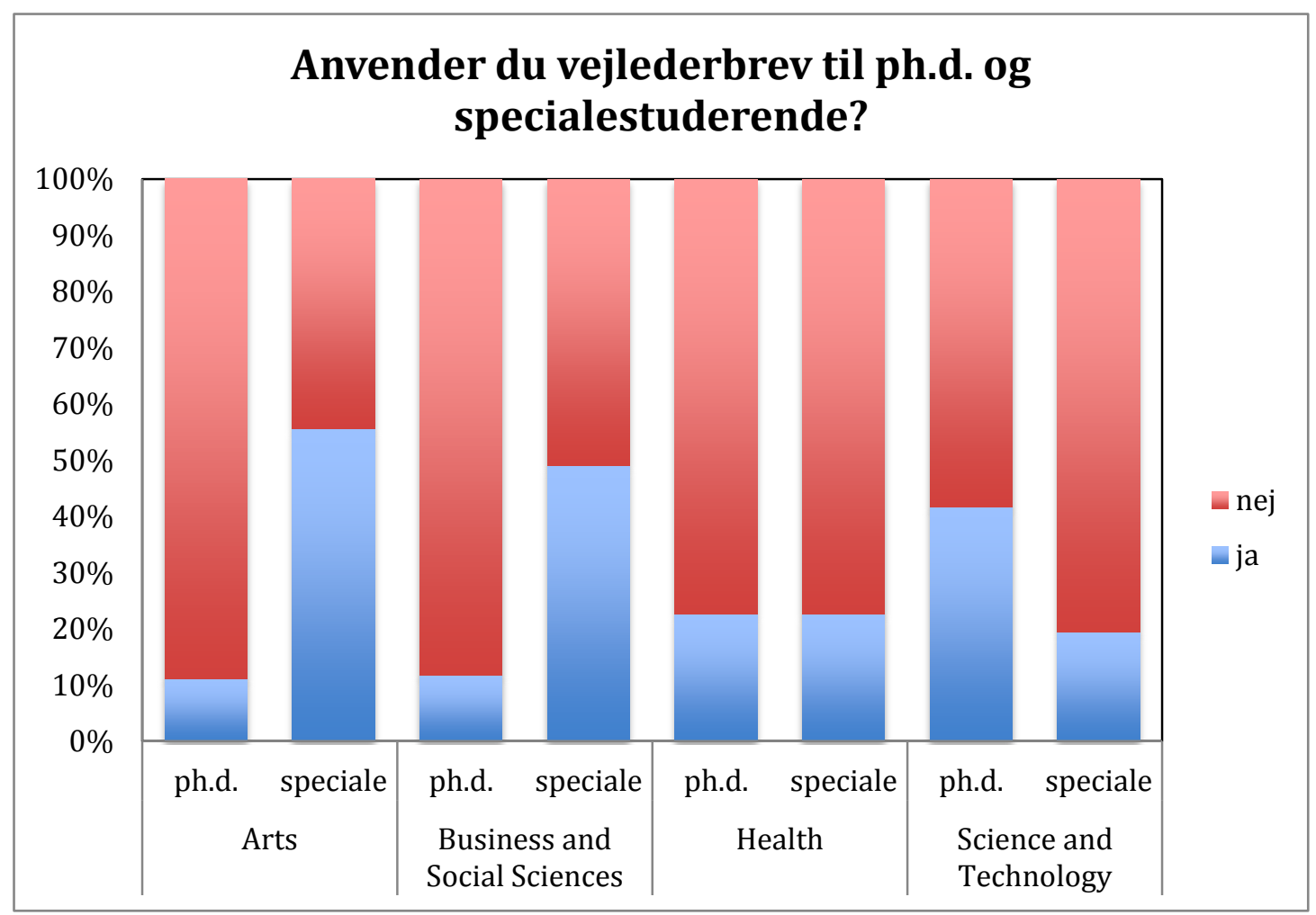

\section{Diskussion}

Undersøgelsen viser, at mindre end en tredjedel anvender vejlederbrevet aktivt ved at udlevere det til studerende. Derimod har ca. $30 \%$ af vejlederne haft overvejelser om vejlederbrevet dog uden at bruge det aktivt. Det er forventeligt med en vis modstand hos vejlederne mod at anvende et nyt redskab, der bryder med traditionel vejledningspraksis. Det er samtidig værd at bemærke, at blandt de, der ikke anvender vejlederbreve, angiver godt en tiendedel, at de overvejer at benytte vejlederbrevet $\mathrm{i}$ fremtiden. Den hyppigste begrundelse for ikke at anvende vejlederbrevet var, at de adspurgte ikke havde fået nye studerende siden vejlederkurset. Denne undersøgelse er foretaget relativt kort tid efter afholdelsen af nogle af kurserne, hvilket kan forklare en begrænset implementering og brug af vejlederbrevet, hvor nogle vejledere ikke har nået at få nye studerende. 
En ting er, hvor mange der bruger vejlederbreve, noget andet er, med hvilken kvalitet og effekt de bruges. Undersøgelsen var ikke designet til at give fyldestgørende svar på sidstnævnte spørgsmål. Alligevel finder vi det relevant at tage hul på diskussionen, da den savnes i litteraturen. Spørgsmålet er, om anvendelse af vejlederbrevet er nok til at skabe sammenhænge mellem læringsmål, vejledningsaktiviteter og vurderingskriterier samt til at påvirke den studerendes læringsaktiviteter i positiv retning? Svaret vil i en konstruktivistisk tænkning være, at vejlederbrevet alene ikke er nok til at skabe alignment. Alignment kræver, at vejleder i enhver kontakt - direkte eller fx i tekstfeedback, skaber rammerne for, at den studerende aktivt arbejder med stoffet i en retning, så der skabes sammenhænge mellem læringsmål og vurderingskriterier. Det teoretiske argument for at vejlederbrevet kan fremme alignment er, at processen med at formulere et vejlederbrev har en bevidstgørende effekt for vejlederen. Uanset hvordan vejlederbrevet efterfølgende anvendes, kan udarbejdelsen af brevet være en bevidstgørelse af vejlederen om at skabe sammenhænge og fremme studieaktiviteter for den studerende i vejledningsprocessen. Argumentet for at skriftliggøre forventninger og praksis er netop ikke kun at eksplicitere og skabe gennemsigtighed for de studerende. Det er lige så væsentligt, at vejlederen bliver bevidst om egen praksis, og at skriveprocessen har en forpligtende form samt en klargørende effekt for skriveren (Dysthe et al., 2001).

Der er en lille tendens til at de tørre fag (Arts og Business and Social Sciences) bruger vejlederbrevet oftere end de våde fag (Health og Science and Technology). En mulig forklaring herpå kan være, at den pædagogiske litteratur har rod i humaniora, hvorfor vejledning oftest diskuteres og undersøges i den humanistiske tradition. Samtidig ligger det ikke fjernt fra den humanistiske tænkning at beskæftige sig med relationer mellem mennesker og reflektere over relationer og læring. Det er veldokumenteret $\mathrm{i}$ uddannelsesforskningen, at læring og vejledning i de våde fag ofte er præget af en traditionel mesterlæretænkning, hvor vejleder og studerende arbejder tæt sammen dagligt fx i et laboratorium, indgår i veletablerede forskningsgrupper, og indgår som parter i et større praksisfælleskab præget af peer- og team-supervision (Seagram et al., 1998; Cullen et al., 1994; Golde \& Dore, 2001; Smeby, 2000). Det kan bevirke, at behovet for at tale om relationer opleves som mindre væsentligt, og at udlevering af vejlederbreve synes overflødigt. I de tørre fag vil vejledningen derimod typisk foregå mellem få personer - ofte i en dyadisk vejlederrelation mellem den studerende og vejlederen. Her er der tale om individuelle opgaver eller forskningsprojekter, hvor der stilles høje krav til den studerendes selvstændighed i arbejdsprocessen, og hvor peer-supervision derfor ikke er oplagt i forløbet (Seagram et al., 1998; Cullen et al., 1994; Golde \& Dore, 2001; Smeby, 2000). Idet vejleder og studerende ikke har en tæt daglig relation, fordrer den dyadiske vejlederform, at der skal skabes tydeligere 
sammenhænge fx med udgangspunkt i vejlederbrevet. Vejlederbrevet kan her blive en legal indgang til skriftligt og mundtligt at italesætte sammenhænge mellem vurderingskriterier og læringsmål samt tydeliggøre, at studerendes læringsaktivitet fremmer udgangspunkt for læring (Biggs \& Tang, 2007).

Den seneste undersøgelse blandt ph.d.-studerende i Danmark viser, at tørre fag har det største frafald blandt ph.d.-studerende (Universitets- og Bygningsstyrelsen, 2007). Dette bekræftes i internationale undersøgelser (Wright \& Cochrane, 2000; Bowen \& Rudenstine, 1992; Rodwell \& Neumann, 2007). Disse undersøgelser giver anledning til at overveje, om tørre fag har et større incitament til at fremme de studerendes studieforhold i form af bl.a. opkvalificering af vejlederkompetencer. Det kan derfor overvejes, om der er brug for at drøfte, om man fremover bør differentiere i brugen af vejlederbreve ved de forskellige hovedområder og på universitetets vejlederkurser. Central rammesætning via et institut eller via specifikke vejlederbreve for hovedområderne kunne være en mulighed i de fag, hvor udlevering af personligt vejlederbrev ikke nødvendigvis giver mening. Her kan identificeres andre veje til forventningsafstemning mellem studerende og vejleder. På den anden side kan processen i udarbejdelse af vejlederbrevet ses som en pædagogisk modning, uanset hvilket fakultet man kommer fra, og hvordan vejlederbrevet anvendes - givet at vejlederbrevet afspejler de ovennævnte kvaliteter. En hypotese kan være, at nytten af at udlevere vejlederbreve afhænger af, hvor tæt samarbejdet i hverdagen er mellem vejleder og studerende. Hvis forventningsafstemning er en naturlig og integreret del af det daglige samarbejde, kan det overflødiggøre udlevering af vejlederbrevet til den studerende. Vejlederbrevet kan i stedet ses som en bevidstgørelse af vejlederen om betydningen af forventningsafstemning. Dette er $\mathrm{fx}$ belyst i tabel 1 , hvor $1 / 3$ svarer, at de har deres vejlederbrev i tankerne under vejledning af studerende. Ovenstående hypotese har ikke kunnet identificeres i litteraturen, hvorfor den bør undersøges i fremtidige, kontrollerede studier.

I nærværende undersøgelse anvendes vejlederbrevet oftere til speciale- end ph.d.studerende (figur 2). En forklaring herpå kan være, at vejlederbrevet har en større berettigelse i kortere og mere intensive vejledningsforløb, hvor det er vigtigt hurtigt at afstemme forventninger og synliggøre sammenhænge mellem læringsmål og vurderingskrav, idet omfang og indhold af vejledning er rammesat anderledes end i et ph.d.-forløb. Vi formoder dog, at forskellen i anvendelse af vejlederbrevet mellem speciale- og ph.d.-studerende udlignes over tid, idet flere i undersøgelsen responderer, at de har tænkt sig at anvende vejlederbrevet i fremtiden og dermed også ved opstart af ph.d.-forløb. 
Det kan undre, at få anvender vejlederbrevet som en synliggørelse af vejledningspraksis på nettet. Dette kan bero på, at vejlederbrevet fortsat er nyt på universitetet. Måske ligger der også en indirekte afspejling af, hvordan undervisningskulturen er på universitetet; at den har et privat præg, og at der endnu ikke er tradition for at synliggøre refleksioner over egne undervisnings- og vejledningspraksisser. En anden forklaring kan være, at vejlederbrevene ikke har en kvalitet der gør, at vejlederne betragter dem som et betydningsfuldt dokument, hvorfor graden af synlighed på nettet er reduceret til et minimum.

Ovennævnte hypoteser kræver både en kvalitativ og en kvantitativ undersøgelsestilgang. Fx bør det udforskes, om der reelt er en forskel i vejledningsrelationen, og dermed hvor anvendelig vejlederbrevet er afhængig af, hvor tæt samarbejdet i hverdagen er mellem den studerende og vejleder. Indholdet og kvaliteten af vejlederbreve bør ligeledes undersøges i relation til, hvorfor vejlederbrevene anvendes eller ej, samt hvilken effekt dokumenterne måtte have på den studerendes læring. Sidstnævnte bør i sidste ende berettige vejlederbrevenes eksistens og anvendelse.

\section{Studiets styrker og svagheder}

Af styrker ved denne undersøgelse kan nævnes, at ca. 2/3 responderede på spørgeskemaet om brugen af vejlederbrev på trods af den korte responstid. Resultaterne kan dog være biased af, at de med størst interesse for vejlederbrevet har taget sig tid til at besvare spørgeskemaet - et selektionsproblem der kan have overestimeret brugen af vejlederbrevet. Stikprøvestørrelsen repræsenterer en tiendedel af VIP-ansatte på universitetet. Undersøgelsen kan derfor ikke ses som repræsentativ for samtlige undervisere på universitetet.

Som tidligere nævnt er undersøgelsen foretaget relativt kort tid efter afholdelsen af kurserne, hvilket kan forklare en begrænset implementering og brug af vejlederbrevene, da nogle vejledere måske ikke har fået nye studerende siden udarbejdelse af vejlederbrevet. På trods af ovenstående antager vi, at vores undersøgelse alligevel afspejler en tendens blandt de, der har været på vejlederkursus og er blevet introduceret til at anvende vejlederbrevet.

I undersøgelsen ses en trend mod, at deltagere fra Arts bruger vejlederbrevet hyppigere end andre hovedområder. Der skal dog tages forbehold for de få deltagere fra Arts. Ligeledes ses, at vejlederbrevet anvendes hyppigere til specialevejledning end til ph.d.-vejledning. Dette resultat kan være biased af den korte implementeringsperiode, hvor vejlederne ikke har nået at få nye ph.d.-studerende. Vi kender heller ikke det absolutte antal ph.d.- og specialestuderende, som respondenterne er vejledere for. Ej heller om der kan være variation mellem antal af kandidat- og ph.d.- 
studerende imellem fagområder samt, om alle undervisere har ph.d.-studerende. Sidstnævnte kan have påvirket vores estimat til at vise en falsk forskel.

Som allerede antydet har implementeringsperioden været forholdsvis kort, og kun få vejledere har nået at deltage i kurserne siden 2008, hvilket sammenlagt begrænser muligheden for at se målbare effekter på den aktuelle vejledningspraksis. Derfor ser det heller ikke ud til, at vejlederbrevet er så integreret en del af vejledningen, at det er naturligt at lægge det ud på hjemmesider.

\section{Konklusion}

Trods vejlederbrevets korte historie på AU ser det ud til, at vejlederbrevet har sin berettigelse - specielt i de tørre fag, hvor vejleder og studerende ikke har et tæt dagligt samarbejde. I våde fag, hvor der er et tæt samarbejde mellem vejleder og studerende, er vejlederbrevet muligvis mindre oplagt at anvende som et direkte redskab til forventningsafstemning. Uanset hvordan vejlederbrevet anvendes, giver selve processen med at formulere et vejlederbrev en forpligtende form og en klargørende effekt. At udarbejde et vejlederbrev kan derfor ses som en pædagogisk modning af vejlederen og dermed som en mulighed for at forbedre betingelserne for de studerendes læringsarbejde i forbindelse med skriftlige opgaver på universitetet. Kvaliteten af indholdet i vejlederbreve har dog afgørende betydning for, at vejlederbrevet kan betragtes som et godt pædagogisk værktøj i vejledningsprocessen, hvilket denne undersøgelse ikke har kunnet besvare.

\section{Taksigelser}

Vi takker kursussekretær Birthe Tillgaard for assistance med maillister og centerleder Torben K. Jensen for hjælp med udformning af spørgsmål til spørgeskemaet.

Sussie Laustsen er cand.cur., ph.d. og adjunkt ved Sektion for Sygeplejevidenskab, Institut for Folkesundhed og Institut for Klinisk Medicin på Aarhus Universitet. Underviser i metode, evidensbaseret viden og kliniske retningslinjer og har undervisnings- og vejledererfaring for såvel kliniske forskningsprojekter, som opgaver på BA-, kandidat- og ph.d.- niveau. Forskningsfeltet omhandler effekten af træning hos hjertesyge patienter på Aarhus Universitetshospital i Skejby.

Gitte Wichmann-Hansen er cand.mag. i Pædagogik, ph.d. i Uddannelsesforskning og lektor ved Center For Undervisningsudvikling og Digitale Medier på Aarhus Universitet. Gitte Wichmann-Hansen underviser og forsker $i$ vejledning - både vejledning knyttet til arbejdspladsoplaring og vejledning $i$ relation til opgave-, projekt- og forskningsforløb på universitetet.

\section{Hanne Aagaard er cand.cur., ph.d. i Sygepleje og adjunkt ved Institut for Folkesundhed på Aarhus Universitet og Børneafdelingen, Århus Universitetshospital. Hanne Aagaard underviser og forsker $i$ 'Complex Intervention' i relation til for tidligt fødte børn og deres familier. Som adjunkt knyttet til}


Sektion for Sygeplejevidenskab er en del af curriculum at yde vejledning til studerende på kandidat- og masterniveau.

Golnosh Bahrami er tandlæge med ph.d. i Odontologi og forskningsadjunkt ved Odontologisk Institut på Aarhus Universitet. Golnosh Bahrami har desuden klinisk undervisning på Odontologisk Institut og er ansat $i$ Region Syddanmark som tandlagekonsulent.

Pia Dreyer er sygeplejerske, cand.cur., ph.d. og adjunkt ved Sektion for Sygeplejevidenskab, Institut for Folkesundhed, Health på Aarhus Universitet. Pia Dreyer underviser og forsker indenfor det intensive område og hjemmerespiratorbehandling med det frnomenologisk hermeneutiske som inspirerende metodetilgang.

\section{Litteratur}

Biggs, J., \& Tang, C. (2007). Teaching for Quality Learning at University. Open University Press.

Bowen, G., \& Rudenstine, N. L. (1992). In Search of the PhD. Princeton: Princeton University Press.

Cullen, D. J., Pearson, M., Saha L. J., \& Spear, R. H. (1994). Establishing Effective PhD Supervision. Canberra: Australian Government Publishing Service.

Dysthe, O., Hertzberg, F., \& Hoel, T. L. (2000). Skrive for at lære. Århus: Forlaget Klim.

Green, H., \& Powell, S. (2005). Doctoral Study in Contemporary Higher Education. Maidenhead: SRHE and Open University Press.

Golde, C. M., \& Dore, T. M. (2001). At Cross Purposes: what the Experiences of Doctoral Students Reveal about Doctoral Education. Philadelphia, PA: Report prepared for the PCT. http://www.phd-survey.org

Handal, G., \& Lauvås, P. (2006). Forskningsveilederen. Oslo: Cappelen Akademisk Forlag.

Harboe, T. (2000). De studerendes forventninger til specialeskrivning - en spørgeskemaundersøgelse. Københavns Universitet, Det samfundsvidenskabelige Fakultet.

Hockey, J. (1996). "A contractual solution to problems in the supervision of $\mathrm{PhD}$ degrees in the UK" in Studies in Higher Education, 21 (3), 359-371.

Holdaway, E., Deblois, C., \& Winchester, I. (1995). "Supervision of graduate students", in The Canadian Journal of Higher Education, 25 (3), 1-29.

Ives, G., \& Rowley, G. (2005). "Supervisor selection or allocation and continuity of supervision: Ph.D students' progress and outcomes", in Studies in Higher Education, 30 (5), 535-55.

Kiley, M. (2003). “Conserver, Strategist or Transformer: The experiences of postgraduate student sojourners", in Teaching in Higher Education, 8 (3), 345-356.

Kiley, M., \& Mullins, G. (Eds.). (2008). Quality in postgraduate research: Research education in the new global environment. Canberra: CEDAM, ANU.

Moses, I. (1985). Supervising Postgraduates. Green Guide No. 3. Australia: Higher Education Research and Development Society of Australia, c/o University of South Wales. 
Rienecker, L., \& Stray Jørgensen, P. (2006). Den gode opgave. Håndbog i opgaveskrivning på de videregående uddannelser. 3. udg. Frederiksberg: Forlaget samfundslitteratur.

Rienecker, L., Harboe, T., \& Stray Jørgensen, P. (2005). Vejledning - en brugsbog for opgave - og specialevejledere på videregående uddannelser. Frederiksberg: Forlaget Samfundslitteratur.

Rodwell, J., \& Neumann, R. (2007). Predictors of Timely Doctoral Student Completions by Type of Attendance: The Utility Pragmatic Approach. Sydney, Australia: Macquarie Graduate School of Management.

Seagram, B. C., Gould, J., \& Pyke, S. W. (1998). “An investigation of gender and other variables on time to completion of doctoral degrees", in Research in Higher Education, 39 (3), 319-35.

Smeby, J-C. (2000). "Disciplinary differences in Norwegian graduate education", in Studies in Higher Education, 25 (1), 53-67.

Taylor, S., \& Beasley, N. (2005). A Handbook for Doctoral Supervisors. London: Routledge.

Universitets- og bygningsstyrelsen. (2007). Undersøgelse af årsager til frafald blandt ph.d.-studerende. København: Epinion Capacent.

Wichmann-Hansen, G., Eika, B., \& Mørcke, A. M. (2007). “Hvad findes der af litteratur om vejledning? -Litteratursøgning med fokus på publicerede, evidensbaserede studier", i Dansk Universitetspædagogisk Tidsskrift, 3, 11-19.

Woolhouse, M. (2002). "Supervising dissertation projects: expectations of supervisors and students", in Innovations in Education \& Teaching International, 39,137-44.

Wright, T. (2003). "Postgraduate research students: people in context?", in British Journal of Guidance \& Counselling, 31 (2), 209-227.

Wright, T., \& Cochrane, R. (2000). “Factors influencing successful submission of PhD theses", in Studies in Higher Education, 25 (2), 181-195. 


\title{
Specialet som glasloft \\ - hvorfor får mandlige studerende bedre specialekarakterer?
}

\author{
Vibeke Lehmann Nielsen, lektor ved Institut for Statskundskab, Aarhus \\ Universitet samt seniorforsker ved SFI. \\ Lotte Bøgh Andersen, lektor ved Institut for Statskundskab, Aarhus \\ Universitet samt Anvendt Kommunal Forskning (AKF). \\ Michael Bang Petersen, lektor ved Institut for Statskundskab, Aarhus \\ Universitet.
}

\section{Reviewet artikel}

Selvom de mandlige universitetsstuderende ikke klarer sig bedre end kvinderne frem til specialet, fär de gennemsnitligt bedre specialekarakterer. Artiklens analyser viser, at det hverken handler om specialevejlederens køn eller om typen af universitetsstudium. Mulige forklaringer, som det er værd for kommende forskning at forfølge, er dels generel diskrimination af kvindelige specialestuderende og dels de studerendes møde med specialet, hoor kønnenes livssituation og/eller deres reaktioner på rollen som specialestuderende kan være forskellige.

\section{Indledning}

Empiriske data fra 2291 universitetsstuderende ved Aarhus Universitet viser, at mandlige studerendes karaktergennemsnit for specialet er 9,4, mens kvindelige studerende i gennemsnit får 9,1 for specialet (begge dele er kontrolleret for, hvilket studium de læser). Det er et tankevækkende resultat, især fordi der ikke er forskel frem til specialet, hvor gennemsnittet for begge køn er 8,1 (igen kontrolleret for studium). Nærværende artikel undersøger, hvorvidt kønsforskellen i karakterer for specialet hænger sammen med vejlederens køn, eller om kombinationen af hhv. mand$\mathrm{lig} / \mathrm{kvindelig}$ vejleder og mandlig/kvindelig studerende har betydning.

Først argumenter artiklen for, hvorfor vejlederkøn og kombinationen af vejleder- og studenterkøn kunne tænkes at have betydning for, at de mandlige universitetsstuderende opnår højere specialekarakterer end de kvindelige studerende. Derefter undersøges forklaringen under anvendelse af registerdata for 2291 studerende fra 11 insti- 
tutter på Aarhus Universitet, og endelig diskuterer vi analyseresultaterne og andre mulige forklaringer.

\section{Betydningen af vejlederens køn}

Der findes kun få studier, der fokuserer på kønnets betydning for vejledning på universiteter (Wichmann-Hansen, Eika \& Mørcke, 2007: 15), men Zegers argumenterer for, at sprogbrugen på universiteterne er maskulin, og at kvinder i vejledningssituationer sprogligt bliver kategoriseret som en social gruppe med mindre magt (2004: 23). Johnson, Lee \& Green (2000: 146) argumenterer i forlængelse heraf for, at der er konflikt mellem kvinders kønsbetingede identitet og den identitet, de forventes at påtage sig som studerende i vejledningssituationer. Argumentet er, at forestillingen om den autonome forsker (dvs. i denne sammenhæng den meget selvstændige specialestuderende) betyder en afvisning af "kvindelige værdier" såsom følelser, personligt engagement og gensidig menneskelig afhængighed. Det kan være en ulempe for kvindelige specialestuderende, især hvis de har mænd som vejledere. Hasse og Trentemøller (2008) finder i forlængelse heraf, at kulturelle mønstre på universiteterne (helt specifikt fysikinstitutter) giver mænd og kvinder forskellige vilkår.

De ovenstående argumenter for, at kvinder har sværere end mænd ved specialeprocessen (i dens nuværende form), kan være forbundet med, at de fleste vejledere er mænd. De eksisterende studier af vejledningsstil peger da også på, at mandlige og kvindelige specialevejledere opfører sig forskelligt. Jensen (2010: 19) fandt fx, at mandlige vejledere talte fire femtedele af tiden under specialevejledningerne, mens kvindelige vejledere kun talte knap tre femtedele af tiden. Der er flere argumenter for, at kombinationen af den studerendes køn og vejlederens køn kan forklare kønsforskelle i forbindelse med specialet, men de peger ikke alle i samme retning.

Et klassisk argument i kønsforskningen kaldes Rip-Rap-Rup-effekten og betegner (især mandlige) lederes tilbøjelighed til at foretrække personer, der ligner dem selv (dvs. mænd). Måske klarer mandlige specialestuderende sig derfor bedre end kvindelige specialestuderende, fordi de mandlige vejledere bedst får øje på de kvalifikationer, som er forbundet med mandekønnet (Højgaard, 1996; Andersen, Bloksgaard \& Christensen, 2009: 71). Idet de fleste vejledere er mænd, kan det potentielt forklare forskellen, selvom kvindelige vejledere må forventes at have den modsatte adfærd (en Kylle-Pylle-Rylle-effekt). Uddannelsesforskningen diskuterer betydningen af lærerens/vejlederens køn lidt anderledes. Her differentieres der mellem passive og aktive lærereffekter (Dee, 2005: 159). Rollemodeltesen forventer en positiv passiv effekt på de studerendes akademiske motivation og forventninger alene på baggrund af tilstedeværelsen af en lærer/vejleder af samme køn. De aktive lærereffekter minder om kønsforskningens forventninger, idet disse udgøres af "unintended bia- 
ses in [teachers'] prior expectations of and interactions with students who have different demographic traits" (Dee, 2005: 159). Implikationen af alle argumenterne er, at mandlige specialestuderende med mandlige vejledere og kvindelige specialestuderende med kvindelige vejledere skulle forventes at klare sig bedre end kombinationerne af mand og kvinde.

Det er imidlertid ikke givet, at de mandlige specialevejledere er skyld i, at de kvindelige studerende mister terræn i forhold til de mandlige i forbindelse med specialet. Hvis man kigger socialpsykologisk på specialevejledningen, kunne man modsat argumentere for en forventning om, at mandlige vejledere faktisk tager sig mere af deres kvindelige end af deres mandlige studerende. En række studier af mænds sociale adfærd har således demonstreret, at mænd er særligt tilbøjelige til at hjælpe kvinder, hvilket fortolkes som et ubevidst forsøg på at tiltrække partnere. Dette gælder især unge, attraktive kvinder (se Buss, 2011: Kapitel 5 og 6).

Omvendt er det ikke umuligt, at de kvindelige vejledere lader deres kvindelige specialestuderende mere i stikken end deres mandlige specialestuderende. Litteraturen bruger betegnelsen "Queen bee syndrome" (bidronningesyndromet) om det fænomen, at kvindelige autoriteter skulle behandle kvindelige underordnede mere kritisk end mandlige underordnede (Staines, Tavris \& Jayaratne, 1974; Ellemers et al., 2004). Bidronningesyndromet kunne forklare, at kvindelige studerende bliver overhalet af mændene under specialeprocessen. Implikationen ville være, at kombinationen af en kvindelig studerende og en kvindelig vejleder giver dårligere karakterer end de tre andre kønsmæssige kombinationer. Og eftersom kvindelige studerende i højere grad søger mod kvindelige frem for mandlige vejledere, kunne dette forklare, at de kvindelige studerende gennemsnitligt set får lavere specialekarakter. ${ }^{1}$. Det er imidlertid vigtigt at være opmærksom på, at en del undersøgelser påviser, at kvinder i hvert fald ikke altid opfører sig som bidronninger (fx Ragins \& Scandura, 1994).

Alt i alt har vi fire bud på forklaringer knyttet til vejlederens køn: (1) Den maskuline dominans på universiteterne slår især igennem ved specialet, og kvinder får især dårlige specialekarakterer hos en mandlig vejleder. (2) Specialevejledere prioriterer de specialestuderende, der kønsmæssigt ligner dem selv, og kvindelige specialestuderende med kvindelige vejledere samt mandlige specialestuderende med mandlige

${ }^{1}$ På de 11 undersøgte institutter på Aarhus Universitet har fire ud af fem mandlige studerende mandlige vejledere, mens to ud af tre kvindelige studerende har mandlige vejledere. Forskellen er signifikant $(\mathrm{p}<0,001)$. 
vejledere får bedst karakterer. (3) Kvindelige vejledere behandler kvindelige specialestuderende dårligere end mandlige specialestuderende, hvilket implicerer, at kvindelige specialestuderende med kvindelige vejledere skulle få dårligst karakterer af alle. (4) Mænd prioriterer (af socialpsykologiske årsager) deres kvindelige specialestuderende højere, end de øvrige specialestuderende bliver prioriteret, hvorved kvindelige specialestuderende med mandlige vejledere skulle forventes at få højeste karakterer.

\section{Kvindedominerede studier og mandedominerede studier}

Før vi vender os mod den empiriske undersøgelse, er der imidlertid en vigtig indvending, der skal tages stilling til. Kvindelige og mandlige studerende er nemlig ikke ligeligt fordelt på de forskellige universitetsstudier, og det kunne meget vel tænkes, at det i sig selv forklarer, at mændene opnår bedre specialekarakterer end kvinderne. På naturvidenskabelige studier (hvor der traditionelt har været relativt mange mænd) får de studerende måske ret lave karakterer på bacheloruddannelsen, mens de kan tænkes at ligge på niveau med (eller over) resten af universitetsuddannelserne, når der gives specialekarakterer. For at imødegå denne indvending er det nødvendigt at kontrollere statistisk for, hvilket institut de studerende kommer fra. Næste afsnit kommer nærmere ind på, hvordan dette er gjort, og hvordan undersøgelsen i det hele taget er gennemført.

\section{Hvordan er undersøgelsen gennemført?}

Enhederne i analysen er 2291 universitetsstuderende, der blev færdige med deres universitetsstudie på 11 institutter (jf. tabel 1 nedenfor) på Aarhus Universitet i perioden 2007 til 2010. Fra universitetets registre har vi oplysninger om disse tidligere studerendes specialekarakter og karaktergennemsnit på den øvrige del af deres universitetsuddannelse. Derudover ved vi, om de er mænd eller kvinder, samt hvilket køn deres specialevejleder havde, og hvilket institut de færdiggjorde specialet på. De 11 institutter er udvalg ud fra det simple kriterium, at de var de eneste institutter på Aarhus Universitet, hvor specialevejlederens køn var registeret. Alle karakterer er opgivet på syv-skalaen (alle specialer er afleveret efter syv-skalaens indførelse, og de øvrige karakterer er dermed enten konverteret til eller givet i henhold til syvskalaen).

\section{Hvad viser analyserne?}

Et simpelt gennemsnit af henholdsvis mandlige og kvindelige studerendes specialekarakterer viser, at hvor mænd i gennemsnit bedømmes med karakteren 9,2, bedømmes kvinder i gennemsnit med karakteren 9,0. Denne forskel er dog ikke statistisk signifikant. Der er dog store forskelle mellem de forskellige universitetsstudiers karakterniveau. Da kønsfordelingen som nævnt også varierer på tværs af studierne, 
er det nødvendigt at korrigere kønsforskellen i karakterer for disse forskelle. Efter denne kontrol er karaktergennemsnittet for mænd 9,4 og for kvinder 9,1. Dette udgør en forskel med en statistisk sikkerhed på 99,8 procent. I absolutte karakterer bedømmes kvindelige studerendes specialer altså i gennemsnit lavere end de mandlige studerendes. Et enslydende resultat findes, hvis vi kigger på relative specialekarakterer - hvis vi altså sammenholder specialekarakteren med den studerendes karaktergennemsnit på resten af uddannelsen. Kontrolleres således for den enkelte studerendes karaktergennemsnit på resten af uddannelsen, opnås samme resultat. Selvom en mandlig og en kvindelige studerende har fået samme karakterer indtil specialet, vil den mandlige studerende altså - i gennemsnit - få en højere specialekarakter. Ser vi på karaktergennemsnittene indtil specialet, er gennemsnittet for både mænd og kvinder 8,1, når der er kontrolleret for studium (uafrundet er karaktergennemsnittet for mænd 8,06 og for kvinder 8,08). Kønsforskellen opstår altså i forbindelse med specialet.

I tabel 1 inddrager vi vejlederens køn som en forklarende variabel. Tabellen viser to regressionsanalyser, der begge kontrollerer for de studerendes institut og karaktergennemsnit frem til specialet. Når vi ser på effekten af de studerendes og vejledernes køn, sammenligner vi derfor (billedligt talt) specialestuderende med samme karaktergennemsnit fra samme institut. Model 1 inddrager derudover hhv. vejlederens køn og den studerendes køn separat. Denne kontrol for vejlederens køn ændrer ikke på den allerede observerede effekt af den studerendes køn. Der er stadig en signifikant forskel på mandlige og kvindelige studerende på 0,26 karakterpoint (de tre stjerner viser, at sammenhængen er over 99,9 procent sikker). Spørgsmålet er dog, hvad der sker, hvis man ser på forskellige kombinationer af den studerendes og vejlederens køn. Er kønsforskellen mellem mænd og kvinder eksempelvis kun til stede ved mandlige vejledere (jf. Rip-Rap-Rup effekten)? Dette undersøges i Model 2, hvor de forskellige kombinationer af studerende- og vejlederkøn inddrages. ${ }^{2}$ Figur 1 illustrerer resultaterne fra model 2. Figuren viser, at kvindelige specialestuderende med både mandlige og kvindelige vejledere får signifikant lavere specialekarakterer, når

\footnotetext{
$22 \mathrm{Vi} \mathrm{har}$ analyseret forskellige mere komplicerede modeller for at teste robustheden af vores konklusioner. For det første har vi undersøgt om effekten af karaktergennemsnit indtil specialet har signifikant forskellig effekt på specialekarakteren for mænd og kvinder. Dette er ikke tilfældet og denne modelspecificering ændrer ikke på de præsenterede konklusioner. For det andet har vi undersøgt om effekten af køn er signifikant forskellig på tværs af de forskellige fag. Dette er heller ikke tilfældet. Endelig har vi undersøgt om kombinationerne af vejlederens og den studerendes køn har signifikant forskellig effekt på specialekarakteren for forskellige fag. Heller ikke dette er tilfældet.
} 
der er kontrolleret for såvel institut som karaktergennemsnit for de øvrige karakterer. Tilsvarende er der i model 2 en forskel på 0,30 karakterpoint mellem mandlige studerende med mandlige vejledere (referencekategorien) og kvindelige specialestuderende med hhv. kvindelige og mandlige vejledere. For de kvindelige studerende med mandlige vejledere er forskellen over 99,9 procent sikker, mens den kun er 95 procent sikker for kvindelige studerende med kvindelige vejledere. Der er ikke signifikant forskel mellem mandlige specialestuderende med hhv. kvindelige og mandlige vejledere, og model 1 fandt, som nævnt, heller ikke nogen selvstændig effekt af specialevejlederens køn.

Sammenfattende er der altså ikke forskel på mandlige og kvindelige vejlederes evne til at "løfte" de studerende gennem vejledningen, mens de studerendes køn har en signifikant betydning for specialekarakteren: Mænd får højere specialekarakterer end kvinder, når der tages højde for deres institut og tidligere karaktergennemsnit.

Figur 1. Estimeret specialekarakter for studerende med 7 i gennemsnit på øvrige karakterer.

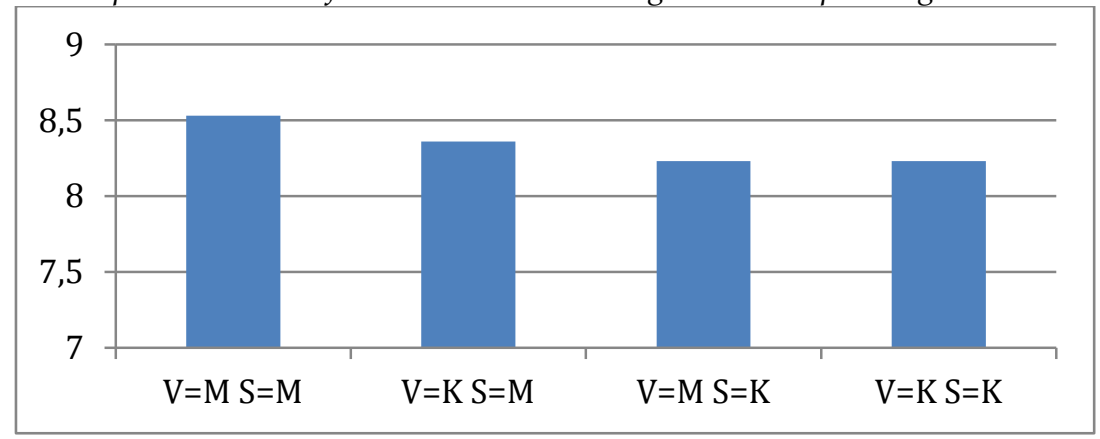

Note: $\mathrm{V}=$ vejleder, $\mathrm{S}=$ studerende, $\mathrm{M}=$ mand, $\mathrm{K}=\mathrm{kvinde}$. Figuren er en illustration af resultaterne $\mathrm{i}$ tabel 1 (model 2) for statskundskabsstuderende med gennemsnit på 7 i øvrige karakterer. Forskellen mellem søjlerne er ikke signifikant forskellig for de øvrige studier eller for studerende med andet gennemsnit.

Yderligere analyser (som kan rekvireres ved henvendelse til forfatterne) viser desuden, at der ikke er nogen sammenhæng mellem de studerendes gennemsnit på den øvrige uddannelse og vejlederens køn. Det er altså ikke sådan, at det ene køn i udgangspunktet får dygtigere specialeskrivere end det andet. Der er heller ikke forskel på mandlige eller kvindelige vejlederes evne til at løfte gennemsnittet fra de øvrige karakterer, og det ene køn er ikke bedre end det andet til at vejlede hhv. bunden og toppen af de studerende. Tabel 1 viser derimod, at der er markante niveauforskelle mellem institutterne, hvilket er udtryk for, at der er variation i, hvor stor forskel der er på øvrige karakterer og specialekarakterer. Der er forståeligt nok også en stærk sammenhæng mellem karaktergennemsnittet frem til specialet og specialekarakteren (1 karakterpoint højere karaktergennemsnit estimeres til at give 0,62 point højere specialekarakter). Det ændrer imidlertid ikke hovedresultatet: Mændene får bedre 
specialekarakterer end kvinderne og det på trods af, at der ikke er forskel på den øvrige del af uddannelsen, og det handler ikke om vejlederens køn.

Tabel 1. Betydningen af vejleders og studerendes køn samt institut for specialekarakteren.

\begin{tabular}{|c|c|c|}
\hline & Model 1 & Model 2 \\
\hline $\begin{array}{l}\text { Konstant (referencekategoriens estimerede speciale-gennemsnit, } \\
\text { hvis gennemsnit på øvrige karakterer=0) }\end{array}$ & $\begin{array}{l}4,17^{\star \star \star} \\
(16,30)\end{array}$ & $\begin{array}{l}4,19^{\star * *} \\
(16,27)\end{array}$ \\
\hline Studenters køn $(\mathrm{M}=0, \mathrm{~K}=1)$ & $\begin{array}{r}-0,26 * \star \star \\
(2,60)\end{array}$ & \\
\hline Vejleders køn (M = 0, K=1) & $\begin{array}{r}-0,06 \\
(0,55)\end{array}$ & \\
\hline Vejleder $=\mathrm{K}$ og studerende $=\mathrm{K}$ & & $\begin{array}{l}-0,30 * \\
(2,16)\end{array}$ \\
\hline Vejleder $=\mathrm{M}$ og studerende $=\mathrm{K}$ & & $\begin{array}{r}-0,30 \text { *** } \\
(2,64)\end{array}$ \\
\hline Vejleder $=\mathrm{K}$ og studerende $=\mathrm{M}$ & & $\begin{array}{l}-0,17 \\
(0,94)\end{array}$ \\
\hline Karaktergennemsnit på den øvrige del af uddannelsen & $\begin{array}{l}0,62^{\star \star \star} \\
(22,70)\end{array}$ & $\begin{array}{l}0,62^{* * *} \\
(22,74)\end{array}$ \\
\hline Biologi & $\begin{array}{r}0,79^{* * *} \\
(3,60)\end{array}$ & $\begin{array}{r}0,80^{\star \star *} \\
(3,63)\end{array}$ \\
\hline Historie og områdestudier & $\begin{array}{r}0,05 \\
(0,22)\end{array}$ & $\begin{array}{l}-0,05 \\
(0,22)\end{array}$ \\
\hline Jura & $\begin{array}{r}-0,19 \\
(1,10)\end{array}$ & $\begin{array}{r}-0,19 \\
(1,07)\end{array}$ \\
\hline Kemi & $\begin{array}{r}1,01^{\star \star *} \\
(2,82)\end{array}$ & $\begin{array}{r}1,02^{\star \star \star} \\
(2,85)\end{array}$ \\
\hline Informations- og medievidenskab & $\begin{array}{r}-0,16 \\
(0,97)\end{array}$ & $\begin{array}{l}-0,16 \\
(0,98)\end{array}$ \\
\hline Molekylærbiologi & $\begin{array}{r}1,50^{\star \star \star} \\
(6,56)\end{array}$ & $\begin{array}{r}1,50^{\star * *} \\
(6,57)\end{array}$ \\
\hline Nordisk & $\begin{array}{c}0,56^{*} \\
(2,58)\end{array}$ & $\begin{array}{r}0,56 * \\
(2,57)\end{array}$ \\
\hline Sprog, litteratur og kultur & $\begin{array}{r}-0,33 \\
(1,70)\end{array}$ & $\begin{array}{r}-0,33 \\
(1,69)\end{array}$ \\
\hline Æstetik & $\begin{array}{r}0,17 \\
(0,95)\end{array}$ & $\begin{array}{r}0,18 \\
(0,96)\end{array}$ \\
\hline Økonomi & $\begin{array}{r}-0,95^{\star \star *} \\
(4,00)\end{array}$ & $\begin{array}{r}-0,96^{\star * *} \\
(4,03)\end{array}$ \\
\hline \multicolumn{3}{|l|}{ Modelstatistik: } \\
\hline $\mathrm{N}$ & $\begin{array}{r}2291 \\
023\end{array}$ & $\begin{array}{r}2291 \\
023\end{array}$ \\
\hline F-test & $53,90^{\star * *}$ & $50,09^{* * *}$ \\
\hline
\end{tabular}

Note: OLS-regression. ${ }^{* *}=p<0,001 ; * *=p<0,01, *=0,05$. Ustandardiserede regressionskoefficienter med t-værdier i parentes. Referencekategorien er i begge modeller mandlige studerende fra statskundskab (for model 2 mandlige studerende fra statskundskab med mandlige specialevejledere). 
Diskussion: Hvorfor er det så, at mændene pludselig får bedre karakterer end kvinderne?

Ud fra analyserne kan vi afvise, at mandlige specialevejledere prioriterer deres kvindelige studerende så meget højere, at det resulterer i højere karakterer (det socialpsykologiske argument), ligesom kvindelige vejledere heller ikke lader til at behandle kvindelige specialestuderende dårligere end mandlige specialestuderende (bidronningeargumentet). Der er heller ikke nogen entydig tendens til, at specialevejledere prioriterer de specialestuderende, der kønsmæssigt ligner dem selv (Rip, Rap og Rup-/Kylle, Pylle og Rylle-argumentet). Resultaterne i den eksisterende litteratur er blandede i forhold til betydningen af lærerens/vejlederens demografiske karakteristika (Dee, 2005: 159), men hvis specialekaraktererne anses for at være relativt objektive vurderinger, er vores resultater konsistente med den eksisterende litteratur. Den viser generelt, at lærerens køn ingen eller kun meget begrænset betydning har for objektive testresultater, mens det kan have væsentlig betydning for lærerens subjektive vurdering af den studerende (Evans, 1992; Ehrenberg, Goldhaber \& Brewer, 1995; Dee, 2005).

Det er muligt, at den maskuline dominans på universiteterne især slår igennem ved specialet, om end det taler imod denne tese, at kvinder får de samme specialekarakterer, uanset om de har mandlige eller kvindelige vejledere. Forestillingen om, at maskulinitet på universiteterne generelt skulle gøre opgaver med store krav til selvstændigheden vanskeligere for kvinder, stemmer heller ikke overens med, at Capacent (2007) finder, at en større andel af de kvindelige ph.d.-studerende gennemfører deres ph.d.-uddannelse sammenlignet med de mandlige ph.d.-studerende. Det er derfor yderst relevant at tænke videre over, hvorfor mændene får bedre karakterer end kvinderne i forbindelse med lige specialet.

En mulig forklaring, som vi desværre ikke kan teste her, vedrører forskelle i livssituationen mellem kønnene. Når universitetsstuderende når frem til specialet, er kvinderne måske blevet mere tiltrukket af og forpligtet overfor et voksenliv. Vi ved, at kvinder tidligere end mænd etablerer sig i parforhold, og at kvinder ofte danner par med mænd, der er et par år eller tre ældre end dem selv. ${ }^{3}$ Forklaringen på mændenes bedre karakterer i forbindelse med specialet kunne altså være, at kvindelige specialeskrivere på dette tidspunkt danner par med mænd, som er på arbejdsmarkedet og i gang med en karriere. Desuden ved vi fra mere generelle studier af køn og arbejds-

${ }^{3}$ Jf. Danmarks Statistik (2011) var gennemsnitsalderen for førstegangsviede mænd i 2010 34,6 år og for førstegangsviede kvinder 32,1 år. 
liv, at kvinder begynder at arbejde mindre, når de får børn, mens mænd arbejder mere (Deding \& Filges, 2009). En anden forklaring knytter sig til forskelle i modning og seriøsitet i forhold til studierne. De mandlige studerende er måske "late bloomers" sammenlignet med de kvindelige studerende, og derfor rykker mændene måske mere fagligt i forbindelse med specialet.

Det er også nærliggende at spørge, om kvinderne skulle blive diskrimineret i forbindelse med specialet. Anonymitet er selvsagt ikke en mulighed, hverken i vejledningen eller i bedømmelsen, og måske har såvel kvindelige som mandlige vejledere højere forventninger til de mandlige studerende end til de kvindelige studerende og er dermed umiddelbart mere positivt indstillede, når specialer fra mandlige studerende censureres. Tidligere studier af og eksperimenter vedr. det akademiske peer reviewsystem, karaktergivning på højere læreranstalter samt optagelsesprøver til symfoniorkestre har antydet, at alene forekomsten af kvindenavne kan føre til en strengere bedømmelse (Goldin \& Rouse, 2000; Swim et al., 1989; Budden et al., 2007). Eftersom vi ikke har haft mulighed for at lade de samme specialer bedømme under to forskellige navne, kan vi ikke undersøge dette stringent, men det er alligevel muligt at komme lidt nærmere en besvarelse af spørgsmålet om diskrimination i universitetsbedømmelser. For alle grunddelsfagene på to statskundskabsinstitutter blev karaktererne registreret sammen med de studerendes og bedømmernes køn. I de fleste fag var bedømmelsen anonym. Nogle fag var dog slet ikke anonyme (mundtlig eksamen), mens andre var semi-anonyme (underviserne havde mulighed for at slå de studerendes navne op via deres årskortsnummer, men navnene optræder ikke automatisk). I disse tre typer eksaminer viste der sig ingen forskel på bedømmelsesadfærden (se Andersen \& Salomonsen, 2010, for en nærmere diskussion af undersøgelsen, der hovedsageligt fokuserer på betydningen af bedømmernes køn). Undersøgelsen giver dog langt fra et fyldestgørende belæg for at afvise påstanden om diskrimination i forbindelse med specialeskrivning, bl.a. fordi forskellige eksamensformer påvirker de studerende forskelligt (Andersen \& Tofteskov, 2008), og bedømmelsesprocessen ved grunddelseksaminer adskiller sig fra specialebedømmelsen.

Det er også muligt, at kvindelige specialestuderende bliver diskrimineret i selve vejledningsprocessen, $\mathrm{fx}$ ved at såvel mandlige som kvindelige vejledere har større ambitioner for mandlige studerende og dermed hjælper og udfordre de mandlige studerende mere end de kvindelige. Det må imidlertid være op til fremtidig forskning at undersøge det aspekt. Heldigvis er der begyndt at blive lukket op for specialevejledningens lukkede rum (Jensen, 2010), og vi opfordrer til, at et af emnerne i denne forskningsdagsorden bliver, om mandlige og kvindelige specialestuderende behand- 
les forskelligt. Spørgsmålet om betydningen af kønsforskelle i livssituation og faglig modning fortjener efter vores mening også videre studier.

\section{Konklusion}

Med denne artikel er vi komme lidt nærmere på at få sikker viden om, hvorfor mandlige universitetsstuderende får bedre karakterer end deres kvindelige medstuderende i forbindelse med specialet, når de på den øvrige del af uddannelsen har fået dårligere karakterer. Resultaterne tyder således stærkt på, at det hverken kan forklares med forskelle i, hvad mænd og kvinder studerer, eller med vejledernes køn. Det er tilsyneladende noget ved specialeprocessen eller ved det tidspunkt i de studerendes liv, hvor de skriver speciale, der stiller de mandlige studerende lidt bedre end kvinderne. Forskellene er ikke overvældende store, men det handler stadig om 0,3 karakterpoint, når der er kontrolleret for institut og karaktergennemsnit på den øvrige del af deres universitetsstudium. Det er selvfølgelig ikke sikkert, at resultaterne kan generaliseres fra Aarhus Universitet til resten af universitetsverdenen, men der er modsat heller ikke nogen god grund til, at sammenhængene skulle være anderledes på andre universiteter.

Som specialevejleder kan man klappe sig selv på skuldrene for, at man tilsyneladende ikke lader sit eget køn få indflydelse på kvaliteten af vejledningen, men der er stadig grund til selvransagelse i forhold til den systematiske forskel mellem mandlige og kvindelige specialestuderende. Er man med specialet med til at skabe det første glasloft, som kvinder møder, hvis de ønsker at gøre karriere? Eller skaber de studerende glasloftet for sig selv? Det får vi forhåbentligt flere studier af, efter at denne artikel har aflivet nogle af de mulige forklaringer på, hvorfor de mandlige studerende får bedre specialekarakterer end kvinderne.

Vibeke Lehmann Nielsen er ph.d. og lektor ved Institut for Statskundskab, Aarhus Universitet samt seniorforsker ved det Nationale Forskningscenter for Velfxerd (SFI). Forfatter og medforfatter til en række artikler og bøger om implementering af offentlig politik, regulering og målgruppeadfærd samt offentligt ansattes adfard - herunder blandt andet betydningen af køn for de offentligt ansattes adfard.

Lotte Bøgh Andersen er ph.d. og lektor ved Institut for Statskundskab, Aarhus Universitet samt Anvendt Kommunal Forskning. Hun er forfatter og medforfatter til en række artikler og bøger om offentligt ansattes motivation, adfærd og performance, herunder betydningen af økonomiske incitamenter, professionelle normer, Public Service Motivation og køn.

Michael Bang Petersen er ph.d. og lektor ved Institut for Statskundskab, Aarhus Universitet. Forfatter og medforfatter til en række artikler om forholdet mellem psykologiske processer og politisk adfærd og holdningsdannelse. 


\section{Referencer}

Andersen, H. L., \& Tofteskov, J. (2008). Eksamen og eksamensformer: Betydning og bedømmelse. Frederiksberg: Samfundslitteratur.

Andersen, L. B., \& Salomonsen, H. H. (2010). "Men and women in public organizations. Do they behave differently? And why should they?" Paper presented at EGPA Annual Conference 8 to 10 September, Toulouse, Frankrig.

Andersen, P. T., Bloksgaard, L., \& Christensen, A. (2009). "Magten ved forhandlingsbordet - et mikrosociologisk blik på arbejdsliv", in Tidsskrift for Arbejdsliv, 11(4), 69-84.

Budden, A. E., Tregenza, T., Aarssen, L. W., Koricheva, J., Leimu, R., \& Lortie, C. J. (2007). "Double-blind review favors increased representation of female authors", in Trends in Ecology and Evolution, 23 (1), 4-6.

Buss, D. M. (2011). Evolutionary Psychology: The New Science of the Mind (4th ed.). Boston: Pearson.

Capacent (2007). Undersøgelse af årsager til frafald blandt ph.d.-studerende. København: Epinion Capacent for Universitets- og Bygningsstyrelsen.

http://www.ubst.dk/publikationer/undersogelse-af-arsager-til-frafald-blandtph-d-studerende/Frafaldsanalyse.pdf (tilgået 12. aug. 2011).

Deding, M., \& Filges, T. (2009). Danske lønmodtageres arbejdstid - en registeranalyse baseret på lønstatistikken. København: SFI - Det Nationale Forskningscenter for Velfærd.

Danmarks Statistik (2011) VIE1. "Gennemsnitsalder for viede mænd og kvinder efter alder". http://www.statistikbanken.dk/VIE1 (tilgået 8. dec. 2011).

Dee, T. S. (2005). "A teacher like me: does race, ethnicity, or gender matter?", in The American Economic Review, 95 (2), 158-165.

Ellemers, N., Heuvel, H. V. D., Gilder, D. D., Maass, A., \& Bonvini, A. (2004). “The underrepresentation of women in science: differential commitment or the queen bee syndrome?", in British Journal of Social Psychology, 43 (3), 315-338.

Ehrenberg, R. G., Goldhaber, D. D., \& Brewer, D. J. (1995). “Do teachers' race, gender, and ethnicity matter? Evidence from the National Educational Longitudinal Study of 1988", in Industrial and Labor Relations Review, 48 (3), 547-561.

Evans, M. (1992). “An estimate of race and gender role-model effects in teaching high school" in Journal of Economic Education, 23 (3), 209-217.

Goldin, C., \& Rouse, C. (2000). “Orchestrating impartiality: the impact of "blind" auditions on female musicians" in The American Economic Review, 90 (4), pp. 715-741.

Hasse, C., \& Trentemøller, S. (2008). Break the Pattern! Report from UPGEM (Understanding Puzzles in the Gendered European Map).

http://www.dpu.dk/fileadmin/www.dpu.dk/upgem/publications/subsites upg em 20081111142604 break-the-pattern-viimane.pdf (tilgået 30. nov. 2011).

Højgaard, L. (1996). Køn og løn. København: Samfundslitteratur.

Jensen. H. N. (2010). "Det lukkede rum - en dør på klem til specialevejledning", in Dansk Universitetspædagogisk Tidsskrift, 8, 17-22. 
Johnson, L., Lee, A., \& Green, B. (2000). “The PhD and the autonomous self: gender, rationality and postgraduate pedagogy", in Studies in Higher Education, 25 (2), 135-147.

Ragins B. R., \& Scandura, T. A. (1994). “Gender differences in expected outcomes of mentoring relationships", in The Academy of Management Journal, 37 (4), 957-971.

Staines, G., Tavris, C., \& Jayaratne, T. E. (1974). "The queen bee syndrome" in Psychology Today, 7, 55-60.

Swim, J., Borgida, E., \& Maruyama, G. (1989). “Joan McKay versus John McKay: do gender stereotypes bias evaluations?", in Psychological Bulletin, 105 (3), 409-429.

Wichmann-Hansen, G., Eika, B., \& Mørcke, A. M. (2007). "Hvad findes der af litteratur om vejledning? - Litteratursøgning med fokus på publicerede, evidensbaserede studier", in Dansk Universitetspædagogisk Tidsskrift, 3, 11-19.

Zegers, V. (2004). Man(n) Macht Sprechstunde. Eine Studie zum Gesprächsverhalten von Hochschullehrenden und Studierenden. Bochum: Ruhr-Universität Bochum. http://www-brs.ub.ruhr-unibochum.de/netahtml/HSS/Diss/ZegersVera/diss.pdf (tilgået 11. aug. 2011). 


\section{"Jonas, derefter Katrine og Sebastian" - en enkel metode til at lære alle de studerendes navne}

Anker Helms Jørgensen, lektor, Innovation og kommunikation, IT Universitetet i København.

Denne artikel præsenterer en enkel, systematisk metode til at lære alle de studerendes navne i universitetsundervisning. Metoden er ret effektiv: I sidste semester lærte forfatteren 30 studerendes navne på 1,5 time; det svarer til 3 minutter pr. studerende og 6 minutter pr. uge. Erfaringen viser, at dette virker fremmende på undervisningsmiljøet. Dette blev bekræftet af en empirisk undersøgelse: De studerende føler sig velkomne, anerkendt og ikke anonyme; det forbedrede atmosferen og gav storre tryghed; og det bidrog til bedre dialog og øget socialisering.

\section{Indledning}

I folkeskolen, gymnasiet og på seminarierne ville det være uhørt, at lærerne ikke kan alle elevernes navne kort tid efter skoleårets start (Wiberg, 2011). Dette gælder også klasser, hvor læreren kun har klassen i én time om ugen (Schmidt, 2011). Det er endda ikke ualmindeligt, at læreren har lært elevernes navne før første undervisning ved at have øvet sig på klassebilledet fra det foregående år (Vadstrup, 2011).

Sådan er det sjældent på universiteterne, hvor mange lærere efterhånden lærer navnene på en håndfuld af de mest aktive studerende: De som svarer på spørgsmål, stiller uddybende spørgsmål og opsøger læreren i pauserne. Min erfaring er, at mange lærere synes, dette er lidt pinligt. Så mange lærere vil gerne mestre de studerendes navne, men det synes helt uoverkommeligt.

Jeg har gennem årene gjort en indsats for at lære de studerendes navne. Dette har efterhånden krystalliseret sig til en metode, som er så afrundet, at den kan kommunikeres til andre.

Metoden består af otte trin, som beskrives så detaljeret i det følgende, at den burde kunne følges af en motiveret læser. Metoden er helt lavpraktisk og udviklet gennem praksis, men den bygger på anerkendt pædagogisk teori, herom senere. Den ligger 
også tæt op ad praktisk orienteret litteratur om hukommelse (fx Higbee, 2001), men den er langt mere specifik og derfor lettere at gå til.

Min erfaring viser, at indsatsen klart står mål med udbyttet, primært fordi undervisningsmiljøet bliver langt mere trygt. Dette blev bekræftet af en undersøgelse blandt de studerende: De føler sig anerkendt og velkomne, ligesom det giver større tryghed og medfører større socialisering, idet de studerende anspores til at lære hinandens navne.

\section{Trin 1: Lav en liste over de studerendes navne}

Første trin består i at hente listen med deltagernes navne, fx fra kursuswebsiden, og alfabetisere den efter fornavn. Jeg arkiverer listen i min Filofax og min bærbare computer. Ideen er at have den lige ved hånden, så jeg kan øve mig når som helst og hvor som helst. Dette trin ligger cirka 2 uger før kursusstart.

\section{Trin 2: Øv navnene ... igen og igen}

Jeg lærer nu navnene udenad gennem et antal sessioner. I første session tager jeg listen med navne og skriver dem langsomt af ét for ét i alfabetisk rækkefølge i kolonner på et blankt A4 ark. Jeg memorerer navnene, "tygger" på dem og noterer mig pudsige sammenhænge: Ingen med A, B og C; fire studerende med "Ma..": Magnus, Malene, Marie, Martin; to Jonas og to Sebastian. Kolonnerne er vigtige da de understøtter "chunking" af navnene. Antallet af kolonner afhænger af antallet af studerende; jeg skriver typisk 10-15 navne i hver kolonne. Jeg lægger især mærke til første og sidste navn i hver kolonne; når de sidder fast, er det lettere at komme i gang med de øvrige navne.

I de efterfølgende sessioner genkalder jeg mig navnene og skriver dem på et blankt stykke A4-ark (free recall). Jeg starter typisk med toppen eller bunden af kolonnerne. Som cues anvender jeg dels de navne, der forekommer flere gange, og dels mønstrene, fx de fire "Ma..". Når jeg ikke kan komme på flere navne, tæller jeg de skrevne navne. Hvis der mangler nogle, finder jeg dem på "facitlisten" og skriver dem på arket på "deres plads". Jeg markerer dem og øver dem. Jeg noterer også antallet af manglende navne, så jeg kan se udviklingen fra session til session. Sessionerne kan ligge lige efter hinanden, på samme dag eller med en eller to dages mellemrum; der bør ikke være alt for længe mellem dem. Dette trin ligger typisk i den sidste uge før kursusstart. Målet er at kunne alle navnene den første undervisningsgang.

\section{Trin 3: Skab ejerskab første undervisningsgang}

Ved den første undervisningsgang præsenterer og motiverer jeg mit forehavende. Jeg sørger for, at alle studerende siger deres navn, når de siger noget, og at alle kommer til orde. En mulighed er at tage en systematisk navnerunde for at starte pro- 
cessen med at knytte navne og ansigter sammen. Det er vigtigt at få de studerende til at tage ejerskab og acceptere det sensitive aspekt af metoden. Muligheden for, at jeg ikke kan huske netop deres navn, ligger lige for og er ikke rar for nogen af parterne. Min erfaring viser, at på trods af den forudgående rene udenadslære oplever jeg i dette trin en vis genkendelse: "Aha, du er Marie ... sådan ser de to Jonas'er ud."

\section{Trin 4: Tag billeder af de studerende ${ }^{1}$}

Jeg tager et billede af alle studerende i vilkårlig rækkefølge første undervisningsgang i en pause. For at være sikker på, at der er synkroni mellem billeder og navne, bruger jeg følgende teknik: Før undervisningen laver jeg en A4-side med numre 1, 2, 3, ... op til antallet af tilmeldte. Jeg laver en skillelinje med teksten FOTO mellem nr. 10 og 11, mellem nr. 20 og 21, osv., se figuren. Ved fotograferingen får jeg en studerende til at skrive de studerendes fornavne og evt. første bogstav i efternavnet i den rækkefølge billeder-
6. PERER H
7. MICHAELN
8. BRIAN
9. VIBEKE
10. $J A C O B$
FOTO
11. ANDRE
12. TRINE ne tages. Efter hver 10. studerende tager jeg et billede af navnelisten (ud for FOTO) for at sikre synkroni mellem billeder og navne.

Jeg benytter også lejligheden til at tage billeder af de studerende set fra lærerpositionen, da dette supplerer læringen af forbindelsen mellem navne og ansigter i trin 7.

\section{Trin 5: Lav et billedgalleri}

Jeg laver en mini-udgave på ca. $4 * 6 \mathrm{~cm}$ (ca. $32 \mathrm{~K})$ af hvert billede ved hjælp af computerens billedprogram. Disse små billeder sætter jeg ind i alfabetisk orden i et Word-dokument med tre søjler med navnene under billederne, se figuren. Den beskedne billedopløsning på $32 \mathrm{~K}$ er fuldt tilstrækkeligt til at sikre skarphed og at Word-dokumentet ikke bliver for stort og uhåndterbart.

Jeg printer billedgalleriet i farver og klipper derefter billederne ud enkeltvis. Jeg beholder enten navnet lige under bil-

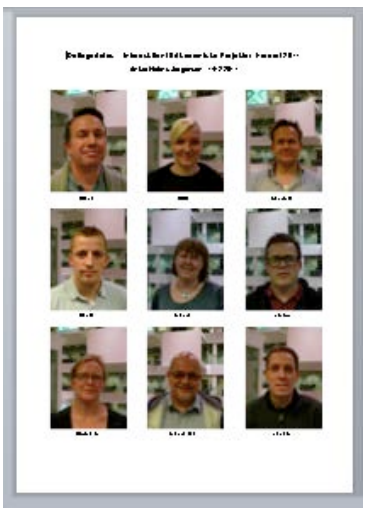
ledet eller klipper det af og skriver det bag på billedet.

\footnotetext{
${ }^{1}$ I modsætning til folkeskolen, gymnasier og seminarier har universiteterne ikke en fast klassestruktur, hvor der foreligger klassebilleder år for år, som læreren kan anvende til at lære elevernes navne.
} 
Trin 6: Gør billedgalleriet tilgængeligt for de studerende

Jeg gør billedgalleriet tilgængeligt for de studerende ved at uploade det på kursuswebsiden for at give dem bedre muligheder for at lære hinandens navne.

Trin 7: Kobl navne og ansigter

I dette trin arbejder jeg med navnene, typisk med udgangspunkt i billedet, da det svarer til praksis: Man ser et ansigt og skal genkalde sig navnet. En måde er at gå billederne igennem et for et og genkalde sig den studerendes navn; jeg siger det gerne højt eller i det mindste "højt inde i hovedet". Hvis jeg er i tvivl, noterer jeg navnet og vedkommendes særlige træk. Jeg blander så billederne og prøver igen.

En anden måde er at genkalde sig hvordan de studerende ser ud. Hvis jeg er sikker: "Jonas ... krøllet, vinduesrækken, snakker meget", så går jeg videre. Hvis jeg er usikker: "Martin ... er det en af de høje, kortklippede fyre?", så finder jeg billedet og øver forbindelsen mellem navn og ansigt. Hvis jeg har svært ved at lære en gruppe, fx de korthårede fyre uden briller, lægger jeg billederne til side og arbejder med disse studerendes kendetegn.

En tredje måde er at lægge alle billederne ud på et bord og lave tilfældige nedslag i den alfabetiske navneliste og udpege den studerendes billede på bordet.

Trin 8: Praktiser og insister!

Det sidste og meget vigtige trin er at praktisere det - og gøre det helt fra starten af anden undervisningsgang. Det fundamentale er, at jeg nævner navnet hver gang en studerende siger noget. Så jeg gør det til en vane, at de studerende markerer når de vil sige noget. Jeg peger på den markerende studerende og siger vedkommendes navn; hvis flere markerer laver jeg en mundtlig talerliste: "Jonas, derefter Katrine og Sebastian." Hvis jeg tøver med et navn, viser erfaringen, at de studerende er meget tilbøjelige til at sige deres navn. Men jeg standser dem, idet jeg insisterer på selv at sige det, også selv om det føles pinligt. Og skulle det ske, at navnet slet ikke dukker op, så beklager jeg det og bruger de andre studerende som ressource: "Hvad er det nu ... hedder?" Herved understøtter jeg, at de studerende lærer hinandens navne og, at de kan vise, at de kan noget, læreren ikke kan.

Der kan være mange årsager til, at et navn ikke dukker op, eller at jeg siger et forkert navn: Måske er billedet af den studerende ikke særligt godt, måske er der tre studerende, der ligner hinanden meget, måske er der tre navne, der minder meget om hinanden og endelig kan en studerende ligne en studerende fra et tidligere semester, hvis navn dukker op først.

I semesterets første uger øver jeg mig ved at gå tilbage til trin 7 og arbejde med billederne, hvor jeg også inddrager billederne af de studerende set fra lærerpositionen. 
Kronen på værket er, når navnene flyder helt frit i undervisningen. Min erfaring er, at det sker ved anden undervisningsgang.

\section{Erfaringer}

\section{Tidsforbrug}

Efterhånden har jeg fået metoden skærpet, så opgaven er overkommelig - ja ligefrem fornøjelig. I sidste semester anvendte jeg metoden i kurset Introduktion til Akademiske Projekter for diplomstuderende med 30 deltagere. I tabellen herunder ses den tid jeg anvendte på de tidskrævende trin uden for undervisningen.

\begin{tabular}{|c|c|c|c|}
\hline Trin & $\begin{array}{c}\text { Trin 1-2 } \\
\text { Lær navnene } \\
\text { udenad }\end{array}$ & $\begin{array}{c}\text { Trin 5 } \\
\text { Lav et } \\
\text { billedgalleri }\end{array}$ & $\begin{array}{c}\text { Trin 7 } \\
\text { Kobl navne } \\
\text { og ansigter }\end{array}$ \\
\hline $\begin{array}{c}\text { Minutter } \\
\text { anvendt }\end{array}$ & $25 \mathrm{~min}$ & $35 \mathrm{~min}$ & $30 \mathrm{~min}$ \\
\hline
\end{tabular}

Tidsforbrug $i$ trinnene uden for undervisningen

Den samlede tid var således 1.5 time ved dette kursus; ${ }^{2}$ dette svarer til 3 minutter pr. studerende og 6 minutter pr. uge i et semester på 15 uger. Jeg anvendte 173 timer til kurset i alt, dvs. de 1.5 time udgør knap $1 \%$ af den samlede tid.

I trin 2 var antallet af manglende navne de første seks gange, jeg skrev navnene på et blankt A4-ark: 5, 0, 0, 0, 0, 0. Så med træning i metoden kan dette trin faktisk være ganske fornøjeligt.

\section{Placering i lokalet}

Jeg har observeret, at de studerendes placering i undervisningslokalet ${ }^{3}$ betyder næsten lige så meget for mig som deres udseende: Katrine sidder konsekvent ved vinduet på første række og Martin sidder altid på bagerste række. Deres påklædning har også meget stor betydning for min læring. Så jeg joker ofte med, at de kan støtte mig i at lære deres navne ved at sidde samme sted i lokalet og have det samme tøj på.

\section{Følsomhed}

Denne tilgang til at lære de studerendes navne kræver en vis portion dristighed, da vores navne er personlige og følsomme, ikke mindst i lyset af magtforholdet mellem lærer og studerende. En studerende vil sandsynligvis opleve det som et nederlag, at

\footnotetext{
${ }^{2}$ Bemærk, at jeg ikke medregner den tid jeg bruger i selve undervisningen, da det er en helt integreret aktivitet og ikke koster ekstra tid.

${ }^{3}$ Det synes også almindeligt, at lærerne i folkeskolen og gymnasiet beder eleverne om at sætte sig samme sted i lokalet de første gange for at skabe et "klassespejl" (Wiberg, 2011).
} 
jeg som lærer tøver eller ikke kan huske vedkommendes navn. Typisk vil jeg kommentere på denne situation på én af to måder. Jeg nævner, at det er lettest at lære navnene på de studerede, der er mest aktive og taler meget. Det er jo fint at tale meget - undervisningen ville være ret kedelig, hvis ingen studerende talte - men det viser sig ofte, at de mere tilbageholdende studerende er blandt dem, der har mest at byde på.

\section{Teoretisk forankring}

Metoden kan forankres i en stor mængde litteratur inden for pædagogisk teori og kognition, specielt ansigtsgenkendelse og hukommelse (Baddeley, 1982; Higbee, 2001). Lad mig helt overordnet bemærke, at grundideen i metoden er skrivning og feedback, som er fundamentale principper i teorier om læring (fx Dysthe et al., 2001), og det kognitionspsykologiske begreb genkaldelse (free recall), som er sværere end genkendelse (recognition), men også resulterer i dybere forankret læring (Colman, 2001, s. 620). Genkaldelsen og skrivningen praktiseres gennem at skrive de studerendes navne igen og igen, mens feedbacken opnås gennem at checke navnene mod "facitlisten" og gennem de studerendes reaktioner i undervisningen. Mere specifikt kan metoden forankres i den pædagogiske teori "den autentiske lærer" (Cranton, 2001; Laursen, 2004). Blandt denne teoris grundprincipper kan nævnes:

- Tydeliggør dine visoner

Dette tydeliggøres gennem at annoncere en måske urealistisk vision om at lære alle de studerendes navne og så gennemføre den.

- Være sikker på, at dine ord og handlinger stemmer overens og vær parat til at indrømme dine fejl

Ved offentligt at vise min egen fejlbarlighed mht. at lære de studerendes navne fremmer jeg accepten af at fejle.

- Vis noget af dig selv som person Dette synes opfyldt, ikke mindst fordi baggrunden er "billig": At stort set ingen andre universitetslærere synes at gøre noget tilsvarende.

- Vis at du tager eleverne alvorligt Vores navne er et fundamentalt aspekt af vores personlighed, hvorfor det at lære andre menneskers navne er at tage dem alvorligt.

- Lad være med at have favoritter blandt de studerende Dette opfyldes ved at insistere på at lære navnene på alle de studerende i stedet for kun en håndfuld af de mest aktive studerende.

- Vxr bevidst om, at du er rollemodel for eleverne Ved at gennemføre en aktivitet, som ligger inden for centrale akademiske 
værdier såsom respekt, tillid og dristighed mener jeg at kunne inspirere de studerende til at gøre noget tilsvarende.

\section{En empirisk undersøgelse af effekten}

En ting er min egen erfaring, en anden er teori, mens en helt tredje er, hvad de studerende mener. For at få indsigt i dette gennemførte jeg en lille empirisk undersøgelse af de studerendes opfattelse af effekten. Jeg lave et mini-spørgeskema med to spørgsmål:

- Har det nogen betydning, at jeg prøver at lære jeres navne?

- Hvis ja, hvilken betydning har det?

Jeg sendte skemaet pr. email til de 50 diplomstuderende, der fulgte mit kursus Introduktion til Akademiske Projekter i foråret og efteråret 2011 (hhv. 29 og 21). Jeg fik 19 svar (hhv. 8 og 11) - det svarer til $38 \%$. Dette er ikke prangende, men nok til at give en rimelig indikation.

Resultaterne viste en klar positiv overvægt: 55 positive ting og 3 negative ting. Det hyppigste svar var at de studerende føler sig velkomne, anerkendt og ikke anonyme (11). Mange angav, at det forbedrede atmosfæren på holdet og gav større tryghed (9), ligesom det bidrog til øget socialisering (5) og bedre dialog (5). De studerende gav udtryk for, at det vidnede om seriøsitet (4) og engagement fra min side (3), ligesom det gav respekt (3), ikke mindst fordi de studerende ikke er vant til dette.

Disse effekter er næppe overraskende, men der kom andre bemærkelsesværdige ting frem. Først og fremmest er de studerende langt mere tilbøjelige til at lære hinandens navne (6), hvad der bidrager til fællesskabet; en studerende angav ligefrem, at det bidrager til at mindske frafaldet. Tre studerende angav, at de anstrenger sig mere for at nå afleveringerne inden fristen, og at de føler sig mere forpligtede. Ydermere mente en studerende, at det "gør én mere modtagelig over for alt det, vi skal have ind i hovedet. "Allermest bemærkelsesværdig var en kommentar fra en meget reflekterende studerende om, at det var en "live præsentation" af værdien af at anvende en metode systematisk, som er en helt fundamental akademisk hjørnesten - en usædvanlig transfer.

Der var imidlertid også ting, der generede eller undrede: Det virker distraherende ("navneleg") eller forstyrrende (2) og vækker undren over, hvorfor dette syntes så vigtigt for mig.

Validiteten af den empiriske undersøgelse kan i høj grad anfægtes, idet jeg har tre roller over for de studerende: 1) Jeg er deres lærer og skal bedømme deres præstatio- 
ner, 2) jeg er udvikler af metoden, og 3) jeg står for undersøgelsen. Men resultaterne synes at give en rimelig entydig indikation og de stemmer godt overens med min egen erfaring. De studerende er voksne mennesker med en professionel baggrund og siger normalt deres mening helt åbent. Således opgiver stort set alle deres navne hvilket er frivilligt - ved de skriftlige evalueringer undervejs i kurset.

\section{Diskussion}

Der er en meget stor individuel variation i menneskers evne til at huske navne og ansigter (Woodhead \& Baddeley, 1981; Higbee, 2001). Så mine konkrete resultater med at lære de studerendes navne kan ikke generaliseres. Og eftersom min performance er et resultat af flere års arbejde med metoden kan andre næppe opnå den samme performance straks - men sandsynligvis efter nogen træning.

Eftersom genkendelse af personer næsten altid er baseret på genkendelse af et ansigt, som man ser, og derpå følgende genkaldelse af navnet, kan min metodes første trin med at lære de studerendes navne udenad diskuteres. Det tager noget tid og kan i sig selv synes overflødigt; men min erfaring viser, at det er med til at give en vis familiaritet med de studerende.

Til sidst kan man med rette spørge om metoden kan bruges til større hold? Jeg har anvendt tidligere varianter af metoden på hold med både 40, 60 og 80 studerende. Og det fungerede, men læringsprocessen tog selvsagt noget mere tid.

\section{Konklusion}

Min metode synes efter flere års udvikling at være rimelig tilgængelig. Metoden synes ret effektiv, idet tidsforbruget ved at lære alle de studerendes navne ved et kursus med 30 studerende som nævnt var 1,5 time, dvs. 3 minutter pr. studerende og 6 minutter pr. uge. At mestre de studerendes navne synes at have en række positive effekter, for eksempel en øget følelse af anerkendelse, større tryghed, øget socialisering, bedre dialog, øget tilbøjelighed til at de studerende lærer hinandens navne og endelig større forpligtelse til at overholde tidsfrister.

\section{Materialer}

På min vejlederblog http://ankervejleder.wordpress.com kan skabeloner for fotolisten og billedgalleriet downloades som Microsoft Word dokumenter.

Anker Helms Jørgensen er lektor på IT Universitetet $i$ København indenfor feltet Human-Computer Interaction. Han har gennem mange år interesseret sig for pædagogik og didaktik, og han har udviklet metoder og metaforer til brug $i$ undervisning og vejledning. Hans vejlederblog kan ses på http://ankervejleder.wordpress.com. 


\section{Referencer}

Baddeley, A. (1982). Your Memory: A Users's Guide. London: Penguin Books.

Colman, A. M. (2001). A Dictionary of Psychology. Oxford: Oxford Unversity Press.

Cranton, P. (2001). Becoming an Authentic Teacher in Higher Education. Malabar, Florida: Krieger Publishing Company.

Dysthe, O., Hertzberg, F., \& Hoel, T. L. (2001). Skrive for at lære. Århus: Klim.

Higbee, K. (2001). Your Memory - How it Works and How to Improve It. Perseus Books.

Laursen, P. F. (2004). Den autentiske lærer. København: Gyldendal.

Schmidt, S. (2011). Personlig email-korrepondance 20/6 2011.

Vadstrup, I. (2011). Personlig email-korrepondance 20/6 2011.

Wiberg, M. (2011): Personlig email-korrepondance 22/6 2011.

Woodhead, M. M., \& Baddeley, A. (1981). "Individual differences and memory for faces, pictures, and words", in Memory and Cognition, vol 9, nr. 4, 368-370. 


\section{Flere studerende - bedre uddannelse}

Carsten Laustsen, direktionsmedlem, studieleder på BDE, AU Herning.

Henning Slavensky, studiementor og virksomhedskoordinator på EDE, AU Herning.

Ina Schmidt, cand.mag., lektiolog (lasepadagog for voksne i videregående uddannelser) underviser i studieteknik, AU Herning.

Per Lysgaard, studieleder på EDE og projektleder på Flere og bedre studerende, AU Herning.

Denne artikel er en praksisorienteret artikel, der omhandler et praksisorienteret projekt på en praksisorienteret uddannelse. Artiklen beskriver tiltag og erfaringer på en uddannelse med henblik på at mindske frafaldet og øge optaget. Det drejer sig om Elektroingeniøruddannelsen på AU Herning, hoor der altid har været et stort frafald. Projektet bag tiltagene er det 2-årige projekt "Flere og bedre studerende". Et projekt med fokus på at mindske frafaldet samt at rekruttere flere studerende. Et større udbytte af uddannelsen for de studerende er et selvfølgeligt delmål.

Af tiltag beskrives funktionen studiementor, mentorvirksomhed, screening for læse-skrivevanskeligheder, studieteknik og pædagogisk dag. I de enkelte tiltag har mål og metode, struktur og bevidstgørelse været kernebegreber.

Siden projektstart er frafaldet reduceret fra ca. $50 \%$ til under $20 \%$.

\section{Projektet "Mere Uddannelse, flere og bedre studerende"}

Frafaldet på Elektroingeniøruddannelsen har altid været højt, på nogle årgange over 50 \%. Pga. såvel det store frafald som et lavt optag blev der sommeren 2008 taget initiativ til projektet "Flere og bedre studerende". ${ }^{1}$

Trods tre individuelle samtaler i løbet af 1 . semester er det ikke tidligere i tilstrækkeligt omfang lykkedes at afdække de studerendes tilsyneladende vidt forskellige be-

\footnotetext{
${ }^{1}$ Projektet "Flere og bedre studerende" er finansieret af et projekt under Region Midtjyllands initiativ

"Mere uddannelse". Projektet er delt op i to delaktiviteter - Mentorvirksomhed og Minimering af frafald

- som kører parallelt og integreret. Projektet er et samarbejde mellem IHA, DPU og AU Herning.
} 
væggrunde for at melde sig ud af uddannelsen. Kunne samtalerne gøres bedre, mere uddybende?

Notater vedrørende de enkelte frafald viste sig dog ved nærmere eftersyn at indikere mulige symptomer på læse- og skrivevanskeligheder. Kunne det tænkes, at et sprogligt område som dysleksi, et hidtil overset område, var medvirkende til frafaldet?

Notaterne angående frafaldet gav, om ikke andet, udtryk for en ofte lav motivation, et manglende engagement hos de studerende. Kunne en undervisning med mere fokus på læring afhjælpe dette? Var den praksisorienterede uddannelse, der bl.a. tilbyder mentorvirksomhed til hver enkelt studerende fra og med 3. semester, ikke praksisorienteret nok?

Ovennævnte overvejelser var grundlaget for projektets fokusområder: Studiementor, mentorvirksomhed, studieteknik, screening for dysleksi og pædagogisk dag.

\section{Målet med projektet}

Med udtrykket "bedre studerende" menes kort sagt, at Elektroingeniøruddannelsen kan forbedres med henblik på at optimere den enkelte studerendes mulighed for optimalt udbytte af uddannelsen samt i sidste ende gennemførelse af uddannelsen.

I løbet af projektet har tre nye årgange påbegyndt uddannelsen: Årgangene 2008, 2009 og 2010. Frafaldet har bevæget sig fra omkring 50 \% til 6 \% på første observerede årgang (se figur 1). De studerende blev informeret om projektet og på den måde inddraget.

\begin{tabular}{|l|l|l|l|l|}
\hline EDE-uddannelsen & $\begin{array}{l}\text { Årgangene } \\
\mathbf{2 0 0 0 - 2 0 0 7}\end{array}$ & Årgang 2008 & Årgang 2009 & Årgang 2010 \\
\hline Optag & 25 (gns.) & 17 & $\begin{array}{l}30(25+5) \\
\text { (danske } \\
\text { +udenlandske) }\end{array}$ & $\begin{array}{l}26(20+6) \\
\text { (danske } \\
\text { +udenlandske) }\end{array}$ \\
\hline Udenlandske frafald & - & 0 & 4 & 1 \\
\hline $\begin{array}{l}\text { Frafald } \\
\text { med perspektiv, } \\
\text { danske }\end{array}$ & - & 1 & 7 & 2 \\
\hline $\begin{array}{l}\text { Frafald } \\
\text { uden perspektiv, } \\
\text { danske }\end{array}$ & - & 0 & 2 & 0 \\
\hline $\begin{array}{l}\text { Frafald totalt } \\
\text { Frafald totalt } \mathbf{i} \%\end{array}$ & - & 1 & 13 & 3 \\
\hline
\end{tabular}

Figur 1. Oversigt over frafald - dokumenteret frafald fra 2000. På årgang 2008 var der tale om 1 frafald med perspektiv. Frafald med perspektiv er frafald, hoor den studerende fortsætter med at studere, men på et andet studium. Frafald uden perspektiv er frafald, hoor den studerende helt opgiver at studere. 


\section{Fra dansk- til engelsksproget uddannelse}

Med henblik på et større optag blev det sideløbende med projektet besluttet at konvertere Elektroingeniøruddannelsen til en engelsksproget uddannelse. Samtidig blev uddannelsens titel ændret til Electronic Design Engineer (EDE). Der er ingen tvivl om, at frafaldet på årgang 2009, 46 \%, har været stærkt påvirket af denne konvertering. ${ }^{2}$ Alle studerende, der valgte at springe fra uddannelsen, har eksplicit givet udtryk for, at det har været problematisk for dem, at undervisningen foregår på engelsk, og enkelte, at det for dem var selve grunden til udmeldelsen af uddannelsen. Andre igen har valgt uddannelsen pga. det engelske. Teamarbejdet, og dermed projektarbejdet, som udgør en væsentlig del af uddannelsen, er ligeledes blevet problematiseret. EDE-uddannelsen står tydeligvis over for en ny udfordring. ${ }^{3}$

\section{EDE-uddannelsen}

Elektroingeniøruddannelsen i Herning startede i 1988, og det første hold dimitterede i 1991 fra det, der dengang hed Vestjysk Teknikum. Siden er Vestjysk Teknikum fusioneret med Handelshøjskolen i Herning (1995) og senere med Aarhus Universitet (2006). Der har altid været et stort frafald på Elektroingeniøruddannelsen i Herning og i de senere år har det været svært at rekruttere studerende. Flere og flere elektronik- og IKT-ingeniørretninger på landets uddannelsesinstitutioner, inkl. AU Herning, har meldt om faldende optag.

Uddannelsen varer $3 \frac{1}{2}$ år inklusiv et $1 / 2$ års praktik og kræver A-niveau i matematik, B-niveau i fysik og C-niveau i kemi. De første to år er en grundlæggende ingeniøruddannelse, hvor der arbejdes med faglighed indenfor elektronikområdet. De studerende får her et solidt naturvidenskabeligt fundament, dvs. indgående forståelse af fysik og matematik. Uddannelsen er, og har altid været, projektorienteret. På uddannelsens afsluttende semestre har projekterne altid været givet af praktikvirksomhederne. Dagligdagen på studiet er delt op i teoretisk undervisning om formiddagen og det praksisrelaterede om eftermiddagen, opgaveregning og projektarbejde. Eksamen i de enkelte fagområder er mundtlig og som regel på basis af en projektrapport.

\footnotetext{
${ }^{2} \mathrm{Al}$ undervisning er nu engelsksproget. Alt studiemateriale har altid været på engelsk. Hvis en gruppe udelukkende består af danske studerende, kan den vælge at skrive og aflevere eksamensrapporter/projekter på dansk. Til mundtlig eksamen er der frit valg mellem engelsk og dansk.

${ }^{3}$ Angående undervisning på engelsk: Se artiklen "Undervisning på engelsk har konsekvenser". Magisterbladet, nr. 6, 27. marts 2009. Og angående samme: http://vtu.dk/nyheder/nyhederudefra/2009/undervisning-paa-engelsk-har-konsekvenser/
} 
Efter de første 2 år vælger de studerende en specialisering, der strækker sig over $3 / 4$ år. Herefter skal de studerende et $1 / 2$ år i lønnet praktik, hvor de studerende indgår i virksomheden som ansatte. Som afslutning på uddannelsen udarbejdes på 10 uger et bachelorprojekt, som regel et projekt givet af praktikvirksomheden. Efter endt uddannelse finder langt de fleste et job i en udviklingsafdeling. Enkelte vælger at læse videre til civilingeniør.

\section{Studiementor}

Tidligere kunne de individuelle samtaler med de studerende som nævnt ikke i tilstrækkeligt omfang afdække de studerendes bevæggrunde for at melde sig ud af studiet. $\mathrm{Nu}$ sørger en studiementor sammen med studielederen for, at samtalerne er mere strukturerede, og at der opnås mere indgående kendskab til de studerendes trivsel og motivation. Samtalerne bygger i første omgang på et motivationsbrev, som den studerende skriver i opstartsugen på første semester. Motivationsbrevet indeholder bl.a. spørgsmål om, hvorfor den studerende netop har søgt ind på EDEuddannelsen, hvor ofte den studerende har tænkt sig at møde op, og hvor meget tid den studerende har tænkt sig at investere i forberedelse.

Studiementoren afholder som minimum to individuelle samtaler med den studerende på både 1. og 2. semester og derudover en del individuelle samtaler efter behov. Studiementoren fører logbog over samtalerne med den enkelte studerende. Umiddelbart inden samtalerne holdes der statusmøder med underviserne på 1. og 2. semester og studiementoren. Der gøres status på såvel det faglige som på trivsel og andre observationer fra de enkelte faglærere. Er der konkrete observationer af eksempelvis manglende opgaveafleveringer, tager studiementoren disse op med den studerende med henblik på at få afklaret, om der evt. ligger et andet mere grundlæggende problem bag, som kan afhjælpes.

Med henblik på at danne sig et indtryk af den nystartede studerende spørger studiementoren ind til den studerendes tidligere uddannelser, hvor den studerende kommer fra, familieforhold, fritidsinteresser etc. Studiementoren gør meget ud af at spørge ind til trivsel i klassen og på AU Herning generelt. Med udgangspunkt i motivationsbrevet spørger studiementoren ind til, hvad der motiverede den studerende til at søge ind på EDE-uddannelsen og hvilke mål den studerende har med uddannelsen. Dette for at kunne understøtte den studerende bedst muligt $\mathrm{i}$ at opnå sine mål. Desuden gøres der opmærksom på muligheden for at blive tilknyttet en mentorvirksomhed - nu langt tidligere i uddannelsesforløbet.

\section{Mentorvirksomhed}

Med henblik på en fra starten mere praksisorienteret uddannelse er muligheden for kontakt med en virksomhed nu flyttet fra tidligere 6. til nu allerede 3. semester. EDE 
udbyder med andre ord nu et mentorvirksomhedskoncept, dvs. et uddannelsesforløb sammen med en virksomhed, hvor der kan være mulighed for, at virksomheden ansætter den studerende efter endt uddannelse. Muligheden for den meget tidligere og større kontakt med en virksomhed forventes, udover en større søgning til EDEuddannelsen, at få en positiv indflydelse på frafaldet.

Mentorvirksomheden tilbyder lønnet praktik, konkrete udviklingsprojekter, afgangsprojekter samt mulighed for lønnet studiejob og studierelevant arbejde i virksomheden i de undervisningsfrie perioder. AU Herning tilbyder at udbyde og markedsføre uddannelsen sammen med virksomheden og at udbyde de af virksomheden ønskede valgfag. ${ }^{4}$ Der er imidlertid endnu ikke virksomheder nok til alle studerende.

Der følges hvert år op på mentorvirksomhedskonceptet ved, at studielederen og studiementoren besøger den studerende og kontaktpersonen i den pågældende virksomhed. Ifølge referater fra disse besøg er alle studerende, der er med i mentorvirksomhedskonceptet, meget tilfredse. De glæder sig til på 6. semester at komme i praktik, idet de til den tid kender alt til virksomheden. Endvidere giver det dem en stor tryghed at vide, at de ikke skal ud at finde en praktikplads. De føler sig ikke bundet til en virksomhed, idet de til enhver tid kan afslutte samarbejdet. Fra virksomhederne er tilbagemeldingen, at mentorordningen fungerer godt, og at de studerende kan udføre en lang række relevante opgaver, som efterfølgende kan anvendes i virksomheden.

\section{Screening for dysleksi}

Som nævnt har der ikke været en entydig forklaring på, hvorfor frafaldet på EDE har været så stort. De studerende har haft vidt forskellige begrundelser for deres udmeldelse af uddannelsen. De korte notater angående de studerendes frafald er en blanding af undervisernes kommentarer og de studerendes udsagn. Fx har en underviser angående en studerende indledende noteret, at vedkommende er "Syg", efterfulgt af en udtalelse fra den studerende, "at studere er stressende", og afsluttet notatet med "mange personlige problemer". Følgende notateksempler er typiske, subjektive undervisernotater: "Er doven! - skulle bestille mere!!!!!", "Meget bagud - kan ikke følge med", "Dumpet - dumper reeksamen", "Er ikke seriøs - er svag - kan ikke klare at studere", "Flyvsk fyr uden fokus", "Vil lave noget mindre akademisk - sprang til

\footnotetext{
${ }^{4}$ Pt. er 11 virksomheder, store som små, tilmeldt ordningen: Velux A/S, Siemens Wind Power A/S, Bang \& Olufsen A/S, DEIF A/S, Mechtronic ApS, Electricon A/S, KK-electronic A/S, Skals Elektronik A/S, SysTek-Skræddergaard El \& Automation A/S, Inventilate, Dantherm Power
} 
EDE fra Datalogi, men synes ikke, at EDE er den rigtige uddannelse, det er for akademisk, leder efter noget mere praktisk, måske en bankuddannelse!?"

Udover ikke-motiverede studerende kan ovennævnte citater indikere dysleksi. ${ }^{5}$ Dysleksi hos studerende i videregående uddannelser kommer til udtryk på vidt forskellige måder. Fx kan nogle studerende med dysleksi komme til at give det indtryk, at de er "dovne", da de enten lader som om, de ikke forbereder sig (i virkeligheden knokler de, men når ikke så meget) eller har så vidt muligt valgt læsning og skrivning fra, da det er meget tids- og ressourcekrævende for dem. Nogle bliver ramt af stress, sygdom, da studierne, pga. læse- og skriveproblemer, bliver alt for uoverskuelige og krævende for dem. Andre forsøger at klare sig igennem og skjuler deres vanskeligheder ved at optræde ukoncentrerede og diffuse eller forvirrede. Nogle har haft en kringlet vej til uddannelsen og er sprunget fra uddannelse til uddannelse.

Til ovenstående skal føjes, at det for dyslektiske studerende i videregående uddannelser typisk gælder, at de ikke ved, hvad det er for vanskeligheder de kæmper med. Mange har en opfattelse af sig selv som doven og/eller dum. Langt, langt de fleste er ikke blevet testet eller på nogen måde afklaret i forhold til de læse- og skrivevanskeligheder, de oplever og altid har oplevet. Dette kommer til udtryk under udredningen af den enkeltes læse- og skrivevanskeligheder. ${ }^{6}$ Bl.a. denne manglende afklaring gør det svært for de studerende selv at henvende sig angående afhjælpning af læseog skrivevanskeligheder. Derfor blev det på EDE-uddannelsen vedtaget at screene alle nye studerende på uddannelsen for dysleksi

Til screeningen blev testen Find det der lyder som et ord anvendt. ${ }^{7}$ Indledningsvis blev de studerende informeret om projektet, symptomerne på dysleksi, samt testen. Typiske symptomer på dysleksi hos studerende er bl.a. at have vanskeligt ved at tilegne

\footnotetext{
${ }^{5}$ Dysleksi (ordblindhed) er vanskeligheder med at (lære at) læse og skrive som følge af langsom og upræcis omsætning af bogstaver og bogstavfølger til sproglyde: http://www.dvo.dk/. Angående studerende på videregående uddannelser se også:

http://www.dpu.dk/uddannelse/raadgivningsogstoettecentret/hvemkanfaastoette/dysleksi/

${ }^{6}$ I bogen I dysleksiens minefelt findes interviews med ordblinde akademikere om skolegang og studier. Find bogen på Rådgivnings- og støttecentrets hjemmeside http://www.dpu.dk/rsc/ eller følg dette link: http://www.dpu.dk/fileadmin/www.dpu.dk/uddannelse/raadgivningsogstoettecentret/publikationerfra rsc/uddannelse rsc 20100913120039 i-dysleksiens-minefelt-3-udg.pdf

7 Testen Find det der lyder som et ord er udviklet som en del af DIAVOK - diagnostisk læsetest for voksne (Nielsen \& Petersen, 1992). Testen fungerer som en god indikator for de vanskeligheder, der kendetegner dyslektikere. (Center for Læseforskning, KU:

http://laes.hum.ku.dk/test/find det der lyder som et ord/om testen/).

Desværre er det ikke muligt at screene på alverdens sprog. Hvis man har dokumentation om dysleksi, fra sit hjemland, er der imidlertid mulighed for rådgivning og støtte. Se http://www.dpu.dk/uddannelse/raadgivningsogstoettecentret/inenglish/
} 
sig nyt stof ved læsning, vanskeligt ved at udtrykke komplicerede sammenhænge skriftligt, usikker stavning. ${ }^{8}$

Testen afdækker færdigheder i at udnytte skriftens lydprincip, dvs. færdigheder i at forbinde bogstaver med lyde. At kunne udnytte skriftens lydprincip er grundlaget for at læse og stave. Langsom og upræcis udnyttelse af lydprincippet er netop kernen i dyslektikeres læse- og skriveproblemer.

Screeningen indikerede læse- og skrivevanskeligheder af dyslektisk karakter hos ca. halvdelen af de studerende. Alle blev efter screeningen tilbudt en uddybende, afklarende samtale. Til samtalen blev studerende med læse- og skrivevanskeligheder tilbudt en testning/udredning. De fleste takkede ja og har efterfølgende modtaget IThjælpemidler og/eller studieteknisk støtteundervisning.

Dysleksi er et handikap. Som dyslektiker kan man derfor søge om Specialpædagogisk Støtte (SPS). SPS skal sikre, at studerende med en fysisk eller psykisk funktionsnedsættelse eller sidestillede vanskeligheder kan gennemføre en uddannelse på lige fod med andre. ${ }^{9}$ Der kan bl.a. ansøges om en IT-startpakke - computer med ordforslagsprogram, talesyntese eller andet kompenserende udstyr, diktafon til notetagning ${ }^{10}$, samt scanner - undervisningsmaterialer på digitale medier, samt studiestøttetimer. ${ }^{11}$ Studiestøttetimer er individuel læsepædagogisk studiestøtte hos en lektiolog (læsepædagog). Den læsepædagogiske studiestøtte tager udgangspunkt i studierelevante tekster, enten den pågældende studerendes læsepensum eller skriftlige opgaver/projekter. Det overordnede formål med et studiestøtteforløb er at gøre den studerende så selvhjulpen som mulig.

\section{Studieteknik}

Formålet med lektionerne i studieteknik er overordnet at bevidstgøre alle studerende om det at uddanne sig, at være på en videregående uddannelse, samt selve uddannelsen. Der gives 4 lektioner på hvert 1. eller 2. semester. I studieteknik arbejdes der

\footnotetext{
${ }^{8}$ Se flere symptomer:

http://www.dpu.dk/uddannelse/raadgivningsogstoettecentret/hvemkanfaastoette/dysleksi/

${ }_{9}$ SPS til studerende på videregående uddannelser: http://www.spsu.dk/vu/index.html

${ }^{10}$ Den studerende med dysleksi har som oftest svært ved at lytte til undervisningen samtidig med at notere. Dette skyldes, at skriftlig formulering kræver dyslektikerens fulde koncentration. Derfor er det for manges vedkommende en stor fordel at optage undervisningen for senere at lytte den igennem, selektere og tage noter.

${ }^{11}$ Se alle støtteformer på http://www.dpu.dk/uddannelse/raadgivningsogstoettecentret/hvemkanfaastoette/dysleksi/stoetteforme rtildyslektikere/
} 
med inspiration fra cooperative learning, undervisning med samarbejdsstrukturer ${ }^{12}$, med overblik og struktur. Struktur på selve uddannelsen, struktur på læsning og skriftligt arbejde, notetagning, samt mundtlige oplæg og mundtlig eksamen. Dvs. EDE-uddannelsens indhold, overgangen til at være studerende på en videregående uddannelse, læse-, note- og skrivestrategier, samt læringsstile via læringsstilprofil. ${ }^{13}$ Læringsstilprofilerne viste imidlertid en overvejende modvilje mod at arbejde i grupper. På EDE arbejdes der i grupper fra og med første semester.

Evalueringerne af studietekniklektionerne har overvejende været positive. For mange er det fx en øjenåbner, at der findes andre/forskellige måder at arbejde på, eller at strukturering af tid/brug af kalender er nyttigt. Studiemiljømæssigt har studieteknikken den positive effekt, at den medvirker til større forståelse for og accept af medstuderendes måske anderledes arbejdsformer.

\section{Fra gruppe- til teamarbejde}

EDE-uddannelsen er og har altid været projektorienteret, og projektarbejde har altid været baseret på gruppearbejde. Et velfungerende gruppearbejde er på uddannelsen fundamentalt for optimal læring og trivsel. Da der, via læringsstilprofilen, viste sig modvilje angående gruppearbejde, blev det derfor vigtigt at få gjort helt klart, hvad man i grunden forventede af og mente med gruppearbejde. Begrebet gruppearbejde blev således udskiftet med begrebet teamarbejde. Projektarbejdet er og har altid været et teamarbejde. Dvs. et samarbejde som i en virksomhed, hvor arbejdet uddelegeres, man mødes og diskuterer, fortsætter arbejdet, osv.

Til de individuelle samtaler bliver der nu talt meget om teamarbejdet, hvad teamarbejde i grunden er, og studiementoren samt studielederen hjælper de studerende med at løse eventuelle konflikter.

Mange studerende fra østeuropæiske lande har et lavt niveau i engelsk, hvilket især fører til problemer med den teambaserede undervisning. Konverteringen fra dansktil engelsksproget uddannelse har som ønsket medført, at der er et større optag af udenlandske studerende, dvs. studerende med forskellige kulturelle baggrunde. Men dette har også givet anledning til nye problemer. Et af problemerne hænger sammen med de studerendes niveau i engelsk. Derudover er de ovennævnte, udenlandske studerende ifølge dem selv typisk vante til et mere autoritært uddannelsessystem og ikke til vores teambaserede arbejdsform. På 1. semester årgang 2009 kla-

\footnotetext{
${ }^{12}$ Kagan, S., \& Stenlev J.: Cooperative Learning, og Skovgaard, M. L.: "Personlige refleksioner over undervisningskvalitet - idéer til tre aktiverende øvelser".

${ }^{13}$ BE, Building Excellence (Dunn and Dunns Learning Styles Assessment)
} 
gede de studerende over dårligt samarbejde, og studiementoren havde mange dialoger med de enkelte teams. De enkelte teams blev bedt om at lave teamnormer og en kontrakt angående forventninger til hinanden. Men kontrakterne blev ikke overholdt, typisk af de udenlandske studerende.

Med henblik på at undgå ovennævnte samarbejdsproblemer sættes nu maksimalt fokus på udenlandske studerende i den første del af uddannelsen. Udenlandske studerende arbejder sammen i teams for sig. Tidligere blev de enkelte teams sammensat på tværs af faglig erfaring, kulturel oprindelse og køn. Det medførte, at de studerende i teamarbejdet skulle kæmpe med sprog, kulturforskelle og andre ikke faglige problemstillinger. Ved at lade de udenlandske studerende arbejde sammen har de mulighed for at koncentrere sig om teamarbejdet, den danske arbejdsform, uden at blive domineret af de danske studerendes viden om denne. ${ }^{14}$

Antallet af studerende i de enkelte teams er ændret fra fire til tre. Dette har vist sig at give en mere jævn arbejdsfordeling og et mere dynamisk teamarbejde. Tidligere var der flere studerende i teams, helt op til fem. De studerende oplevede derfor ikke, at det var et problem, hvis en i teamet ikke deltog, hvilket de imidlertid gør nu, hvor de kun er tre i teamet. Det betyder, at de kræver at alle deltager i møderne og alle bliver nødt til at bidrage og være aktivt deltagende.

\section{Pædagogisk dag for underviserne}

Med henblik på bevidstgørelse af underviserne om motivation og optimeret læring afholdes der pædagogisk dag mindst en gang pr. semester. Underviserne har vist stor interesse for optimering af kommunikationen i undervisningen samt stor interesse i at dele og diskutere undervisningserfaringer og - idéer med hinanden.

De pædagogiske dage tager typisk udgangspunkt i en artikel eller et oplæg, fx Undervisning i Ingeniørarbejde, DTU-modellen, Building Excellence (BE), læringsstilprofil, eller i studieteknikken og diskussion af implementering af denne i undervisningen.

\section{Effekt af projektet - og fremtidigt}

De oprindelige overvejelser og de deraf følgende tiltag har haft en kolossal indflydelse på hele EDE-uddannelsen. Målene med projektet er nået: Optaget er øget, frafal-

\footnotetext{
${ }^{14}$ http://videnskab.dk/kultur-samfund/skaev-kritik-af-udenlandske-studerende http://www.24.dk/article.jsp?articleId=11094
} 
det er mindsket, og karaktergennemsnittet er steget. ${ }^{15}$ Af bonuseffekter kan nævnes en hurtigere og større åbenhed de studerende imellem omkring det at studere. Det er en åbenhed, der er til gavn for hele læringsmiljøet.

I løbet af projektet påbegyndte 3 årgange EDE-uddannelsen. Fokus på dysleksi mindskede frafaldet betragteligt på alle årgange. Den anden årgang, med start i 2009, fik et stort frafald på grund af optaget af udenlandske studerende. Ved at ændre sammensætningen af teams på den efterfølgende årgang, faldt frafaldet igen betydeligt.

Erfaringen er, at fokus på dysleksi mindsker frafaldet øjeblikkeligt. De nye tiltag, bl.a. den nye sammensætning af teams, medfører, at de enkelte teams fungerer meget bedre end tidligere. De kulturelle problemer i teams er ikke længere et issue. I de udenlandske teams er der et godt samarbejde og aftaler overholdes. Der er desuden et udpræget samarbejde på tværs af alle teams. Fokus på de studerendes trivsel er generelt af stor vigtighed - dårlig trivsel stort frafald.

De studerende, som påbegyndte uddannelsen under projektet og fik etableret en aftale om mentorplads, har alle sikret sig et virksomhedsprojekt på 5. semester og en praktikplads i deres mentorvirksomhed. Der er ingen tvivl om, at garanti for et virksomhedsprojekt, praktikplads og evt. afgangsprojekt og efterfølgende job har en positiv indflydelse på frafaldet. ${ }^{16}$ Der arbejdes til stadighed på at etablere flere mentorvirksomhedsaftaler.

Erfaringerne med dysleksi har ført til beslutning om investering i et oplæsnings- og et medskrivningsprogram, der stilles til rådighed for samtlige studerende på uddannelsen. Angående dysleksi er det vores inderlige håb og ønske, at vores erfaringer først og fremmest kan være medvirkende til en tidligere indsats. Her tænker vi pri-

\footnotetext{
${ }^{15}$ Disse mål er i øvrigt sammenfaldende med anbefalinger fra Ministeriet for Videnskab, Teknologi og Udvikling. Undersøgelsen i Flere og bedre Ingeniører, Anbefalinger 2005 (p. 8) peger på, at der skal sættes ind på 3 fronter: Øget optag, flere kvinder og ned med frafaldet. Ifølge undersøgelsen vil en reduktion af frafaldet alene kunne klare næsten hele problemet: "En reduktion i frafaldet på uddannelserne vil i sig selv kunne klare næsten hele problemet, men det vil kræve en kæmpe indsats af særligt universiteterne og ingeniørhøjskoler og kan ikke ske fra den ene dag til den anden. I dag falder en tredjedel af de studerende fra undervejs. Hvis frafaldet kan bringes ned, så kun 20 procent falder fra, vil det give 6.000 ingeniører mere i 2020".

${ }^{16}$ Samarbejde mellem virksomheder og universiteter angående praktik er en af de anbefalinger som bliver givet i Flere og bedre Ingeniører, Anbefalinger 2005 (p. 4): "Universiteter og ingeniørhøjskolers samarbejde med virksomheder om praktik skal styrkes, så praktikerfaringerne udnyttes bedre på uddannelserne både af lærere og studerende".
} 
mært på tidlig indsats i folkeskolen og dermed selvfølgelig først og fremmest grundig undervisning i og oplysning om dysleksi på seminarierne.

Af projektoplægget fremgår det, at udbyttet af projektet skal medføre implementering af tiltagene på samtlige ingeniøruddannelser på AU Herning, samt have indflydelse i hele regionen. Vi anbefaler og håber på udbredelse og indflydelse langt ud over regionens grænser.

Carsten Laustsen. Vice-uddannelseschef, studieleder for Business Development Engineer-uddannelsen (BDE), studieleder for Teknologisk Diplom-uddannelsen (TD), lektor på AU Herning. Teknikumingeniør indenfor svagstrøm. Arbejder hovedsagelig med ledelse.

Henning Slavensky. Lektor, studiementor på Electronic Design Engineer-uddannelsen (EDE) $A U$ Herning. B.Sc.E.E., Master of IT - Interaction Design and Multimedia. Vejleder og underviser i software, digital elektronik og interaktionsdesign.

Ina Schmidt. Lektiolog (akademisk læsepædagog) Rådgivnings- og støttecentret, AU. Lektiolog og cand.mag. Tester og udreder for dysleksi, giver studiestøtte og underviser i studieteknik.

Per Lysgaard. Studieleder for Electronic Design Engineer-uddannelsen (EDE) lektor, AU Herning. Teknikumingeniør indenfor svagstrøm. Stud.polyt., teknologibaseret ledelse. Arbejder hovedsagelig med ledelse, vejleder i projekter og underviser $i$ analog teknologi.

\section{Referencer}

DVO, Dansk Videnscenter for Ordblindhed: http://www.dvo.dk/

Justesen, H. T., \& Pedersen, A. L. (2010). I dysleksiens minefelt. Rådgivnings- og støttecentret, Århus: Aarhus Universitet, Danmarks Pædagogisk Universitetsskole.

Jørgensen, P. S., \& Rienecker, L. (2009). Studiehåndbogen - for studiestartere på videregående uddannelser. København: Samfundslitteratur.

Kagan, S., \& Stenlev J. (2006). Cooperative Learning. Undervisning med samarbejdsstrukturer. København: Alinea.

Lauridsen, O. (2007). Fokus på læring - om læringsstile $i$ dagligdagen - professionelt og privat. København: Akademisk Forlag

Læringsstilprofil. BE, Building Excellence (Dunn and Dunns Learning Styles Assessment):http://www.building-excellence.com/

McLoughlin, D., Leather, C., \& Stringer, P. (2002). The Adult Dyslexic. Interventions and Outcomes. London: Whurr Publishers Ltd..

Ministeriet for Videnskab, Teknologi og Udvikling (2005). Flere og bedre Ingeniører, Anbefalinger. København.

Ministeriet for Videnskab, Teknologi og Udvikling (2009). Undervisning på engelsk har konsekvenser: $\quad$ http://vtu.dk/nyheder/nyheder-udefra/2009/undervisning-paaengelsk-har-konsekvenser/

RSC, Rådgivnings- og støttecentret. http://www.dpu.dk/rsc/ 
Skovgaard, M. L. (2010). "Personlige refleksioner over undervisningskvalitet - idéer til tre aktiverende øvelser", in Dansk Univeritetspædagogisk Tidsskrift, årgang 5, nr 8.

Tang, H. (2009). "Undervisning på engelsk har konsekvenser", in Magisterbladet, nr. 6. 


\section{At undervise på poststrukturalistisk - undervisning i organisation og ledelse som en selv-refleksiv iagttagelsesmaskine}

Christa Breum Amh $\phi$, seniorforsker, SLIP-programmet, CBS.

Den offentlige sektor er i krise og skal genopfindes, lyder den danske ledelsesdebat. Lederuddannelser som MPA og Diplom i Ledelse udpeges som svar på, hvordan vi kan skabe de ledere, der med refleksiv distance proaktivt kan sætte præmisserne for, hvordan den skal genskabes. Men hvordan kan vi indenfor de eksisterende undervisningsformer omsætte ledelsesdebatten $i$ en konkret undervisning $i$ organisation og ledelse? Sådan lyder spørgsmålet $i$ nærværende artikel. Artiklen er normativ $i$ den forstand, at den giver et bud på, hvordan undervisning $i$ organisation og ledelse kan designes, så den ikke blot ansporer de studerende til læse og anvende tekster, der handler om at genopfinde den, men også fär et glimt af, hvordan de selv er - og proaktivt kan være - med til at genopfinde, skabe og lede den offentlige sektor gennem deres valg af iagttagelser af organisationen. Artiklen tilbyder ikke ny viden om organisation og ledelse eller nye undervisningsteknikker men viser, hvordan forholdsvis velkendte teknikker ud fra en poststrukturalistisk optik bliver en slags social teknologi. Herfra bliver de ikke neutrale metoder til at formidle eller anvende en ny viden om vores organisationer. Derimod bliver de teknikker, hoormed man som underviser proaktivt kan skabe betingelserne for en ny måde at se på.

\section{Indledning}

Pointen i mange danske bøger om ledelse af den offentlige sektor handler om, at den offentlige sektor i disse år genopfindes (Pedersen, Greve \& Højlund, 2008; Pedersen, 2004; Sløk \& Villadsen 2008; Pedersen, 2011; Melander 2008). Vi ved ikke længere, hvad en "stat", en "kommune" og en "forvaltning" er, og vi ved ikke længere, hvad det vil sige at være en leder, medarbejder og en borger, lyder det. En af grundene er, at vi i disse år ser en eksplosion af styringsteknologier i den offentlige sektor: coaching, værdibaseret ledelse, elevplaner, kontrakter, kompetenceudviklingshjul, MUS, reflekterende teams, selvstyrende teams mm. Disse teknologier kan ikke blot iagttages som neutrale instrumenter, der objektivt kategoriserer, inddeler, måler og evalu- 
erer vores organisationer. De kan også forstås som sociale teknologier (Foucault, 1997), der på forskellige og ofte modstridende måder skaber betingelserne for, hvad en organisation og et medlemskab overhovedet er (Amhøj, 2007; Dean, 1999; Rose, 1999; Tangkjær \& Thygesen, 2004). For Pedersen, Greve \& Højlund ligger "Genopfindelsen [..] ikke i et nyt design eller i en klar reformidé, men snarere i sprækkerne, spændingerne og de strategiske valg, der følger af en stadig mere flydende og internt differentieret sektor, som sættes under pres" (Pedersen, Greve \& Højlund 2008). Der er også andre, der deler diagnosen om, at den offentlige sektor konstant er til forhandling og konstant bliver til og som understreger, at det skaber et solidt styringspres for den enkelte. (Amhøj, 2007; Andersen, 2004; Andersen \& Thygesen, 2004; Dean, 1999; Pedersen, 2004; Rose, 1999). Nogle taler om den polyfone organisation (Andersen, 1999; Rennison, 2004). Det vil sige en organisation, der bliver til gennem en mængde af forskellige koder og diskurser, hvor det ikke længere er muligt at finde en superkode, der binder dem sammen. Enhver kode falder ned ved siden af de andre.

Uanset hvordan studierne viser, at organisationen dukker op på nye måder, stiller det nye krav til lederen, når den formelle organisation tilbagetrækkes, og når de formelle roller ikke på forhånd er givet. Groft sagt kan man sige, at pointen i mange af disse ofte poststrukturalistiske studier af offentlig ledelse handler om, at en leder ikke bare skal være i stand til eksempelvis at kunne trække på dominerende ledelsesdiskurser eller anvende styringsteknologier som coaching, værdibaseret ledelse, kontrakter, årsplaner, reflekterende teams, narrativ ledelse, person- og klientorienteret terapi mm. Lederen skal også kunne iagttage, hvordan ledelsesdiskurserne, styringsteknologierne og sprækkerne mellem dem skaber og leder vores organisationer, fordi de iagttager dem på særlige måder (Tangkjær \& Thygesen, 2004). Det er ledernes iagttagelse af deres egne iagttagelse som konstituerende for praksis, der skaber ledernes handlekraft, synes den minimale præmis at lyde i disse studier (Andersen, 2003; Tangkjær \& Thygesen, 2004; Amhøj, 2007; Pedersen, Greve \& Højlund, 2008). Det er det blik for iagttagelse, der gør, at de proaktivt kan vælge, hvordan de så vil skabe organisationen i dette mylder af koder og diskurser. ${ }^{1}$ I denne artikel vil jeg

\footnotetext{
${ }^{1}$ Det kommer også til syne på forskellige uddannelser, der har fag, der handler om organisation og ledelse. Her er overblik over teori om styringsteknologier og styringsteknologiers konstituerings - og handlekraft eksempelvis i centrum for analyse. Se eksempelvis studieordninger for faget Styringsteknologiernes former på CBS (2009) og Pædagogiske Psykologiske perspektiver på Intervention på DPU (2009) eller en konkret evaluering af MPA uddannelsen (Pedersen \& Nielsen, 2011). Der er naturligvis også andre og konkurrerende perspektiver på den offentlige sektor, der ikke tager afsæt i poststrukturalistiske perspektiver, men det vil være at gå for langt at gå i dybden med dem her. Det, artiklen vil fo-
} 
skrive mig ind i diskussionerne om vores lederuddannelser og i vores diskussioner om undervisning i organisation og ledelse samtidig med, at jeg vil være i "periferien" af dem. Udgangspunktet for denne artikel er nemlig hverken en analyse, evaluering eller en beskrivelse af MPA, Diplom i Ledelse eller kreative partnerskabsprojekter i kommunerne (se eksempelvis Helth, 2011). Derimod vil jeg med afsæt i de eksisterende rammer, der er, som underviser på et universitet, spørge: Hvordan kan vi ikke bare undervise i ovenstående poststrukturalistiske perspektiver på ledelse, men også tilrettelægge og designe en undervisning poststrukturalistisk således, at vi kan anspore de studerende til at blive 'selv-refleksive iagttagelsesmaskiner', der kan iagttage, hvordan deres valg af iagttagelse er med til at forme og skabe den offentlige sektor og i den forstand er med til at genopfinde den? Artiklens væsentligste bidrag er ikke nye undervisningsteknikker men derimod et blik for, hvordan forholdsvise velkendte undervisningsteknikker som undervisningsbeskrivelse, intro, cases, spejling i grupper og dét at læse undervisningen bagfra kan bruges i en poststrukturalistisk optik, hvor det ikke handler om at anvende teorier på praksis eller at få kendskab til mere teori. Det, det handler om, er derimod, hvordan man kan etablere et særligt blik på organisationen (Andersen, 2003). Artiklen vil vise, hvordan nedenstående undervisningsteknikker kan bruges til at konstituere undervisningen som en selvrefleksiv iagttagelsesmaskine:

Figur 1

\begin{tabular}{|l|l|}
\hline Undervisningsteknik & Mål \\
\hline Personlig fortælling & $\begin{array}{l}\text { At skabe distance til organisationsteori som et spørgsmål om at lede efter de } \\
\text { rette modeller, intentioner, essenser og kulturer. At anspore de studerende } \\
\text { til at knytte an til en undervisning, der handler om at iagttage iagttagelser } \\
\text { som iagttagelser, der gør en forskel for organisationen, dens problemer og } \\
\text { løsninger. }\end{array}$ \\
\hline Tre analysestrategier & $\begin{array}{l}\text { At skabe den iagttagelsesmaskine der ansporer de studerende til konstant at } \\
\text { forstyrre, destabilisere og forskyde deres blik på organisationen og at få dem } \\
\text { til at se, hvordan det gør en forskel for, hvilke problemer og løsninger de ser. }\end{array}$ \\
\hline En case & $\begin{array}{l}\text { At anspore de studerende til knytte an til iagttagelsesmaskinen og dermed } \\
\text { ambitionen om konstant at forskyde iagttagelsespositionen. At få dem til at } \\
\text { blive til skarpladte iagttagelsesmaskiner. }\end{array}$ \\
\hline $\begin{array}{l}\text { Ekspertpanel/spejling } \\
\text { i grupper }\end{array}$ & $\begin{array}{l}\text { At anråbe dem som handlekraftige studerende, der kan iagttage organisation } \\
\text { - og efterfølgende iagttage deres iagttagelser som iagttagelser, der gør en } \\
\text { forskel. }\end{array}$ \\
\hline $\begin{array}{l}\text { At læse undervisnin- } \\
\text { gen bagfra }\end{array}$ & $\begin{array}{l}\text { At synliggøre den poststrukturalistiske metapræmis som har struktureret } \\
\text { undervisningen. Eksplicitering kan anspore de studerende til at bevæge sig } \\
\text { fra første ordens til anden ordens iagttagelser og til at bruge denne bevægel- } \\
\text { se (fra den nære til den distancerede iagttagelse) til selv proaktivt at skabe og } \\
\text { genopfinde organisationer. }\end{array}$ \\
\hline
\end{tabular}

kusere på, er nemlig, hvordan vi kan omsætte ledelsesdebatten, som den er skitseret her, i forhold til undervisning i ledelse og organisation. 
Analysen af, hvordan jeg har brugt teknikkerne til at skabe præmisserne for undervisningen, giver mulighed for, at man som underviser gennem sine valg af teknikker kan arbejde proaktivt med at sætte præmisserne for "videnproduktionen" som en produktion af iagttagelser af iagttagelser og med at "produktionsmedlemmerne" bliver til selv-refleksive iagttagere.

Samtidig åbner perspektivet op for, at der er lighedspunkter mellem at være underviser og at være leder. Begge dele handler om at bane vejen for at iagttage iagttagelser som iagttagelser, der sætter en konstituerende forskel. Artiklen vil afslutningsvis perspektivere designet af undervisningen ved at vende grundproblematikken på hovedet og spørge: Hvilke konsekvenser har undervisningen som denne "selvrefleksive iagttagelsesmaskine" så i forhold til ledelsesdebatten?

\section{Det empiriske materiale og hvad kan det sige noget om?}

Rammen for den undervisning, jeg om lidt vil begrunde, udfolde og analysere, er Danmarks Pædagogiske Universitetsskole i år 2009. Undervisningen var en del af kandidatuddannelsen i pædagogisk psykologi og udgjorde et kursus på uddannelsens modul 3, der bærer titlen "Subjektivering, læring og diversitet", hvor et tema i forløbet er organisationsteori. I alt deltog 125 studerende. Titlen for undervisningen var "Organisationen iagttaget fra et poststrukturalistisk perspektiv". Undervisningen var sat til 6 timer på én dag. Den blev superviseret af en kollega fra et andet universitet $\mathrm{i}$ forbindelse med mit adjunktpædagogikum. Eksemplerne i artiklen tager primært afsæt i mine egne overvejelser og design af undervisningen, min kollegas observationer og samtaler med de studerende på holdet. Jeg er ikke interesseret $\mathrm{i}$ at evaluere, måle eller på anden måde kategorisere, hvorvidt den konkrete undervisning var en succes eller ej. Det, der er i fokus i artiklen, er udelukkende en analytisk interesse for, hvordan forholdsvis velkendte undervisningsteknikker kan italesættes, designes og sammensættes ud fra en poststrukturalistisk optik i forhold til at skærpe de studerendes blik for iagttagelser som konstituerende for organisationen. Hvordan skaber de betingelserne for iagttagelserne og for iagttagelserne af iagttagelser? Det er det, der er interessant at belyse i forhold til det empiriske materiale.

\footnotetext{
Metateoretisk udgangspunkt - fra anvendelse til undervisningen som en iagttagelsesmaskine

Ledelsesdebatten (som skitseret ovenfor) og den poststrukturalistiske metapræmis har, som vi nu skal se, konsekvenser for, hvordan man kan tænke og designe en undervisningsgang, der i studieordningen, handler om at give de studerende indsigt $\mathrm{i}$ organisationsteori. Groft sagt kan man sige, at det bliver relevant at designe undervisningen således, at de studerende får blik for, hvorvidt og hvordan vores viden om organisationer ikke blot er en neutral afspejling af verden "derude" men også er med til at skabe organisationer og dermed også vores organisatoriske problemer og løs-
} 
ninger på særlige måder, der udelukker andre. Med det valgte perspektiv bliver det centralt at forskyde undervisningen fra, at vi diskuterer teorier om organisation og ledelse i forhold til, hvad der er mere eller mindre rigtigt og sandt i forhold til vores egne og andres erfaringer, praksis eller viden om virkelige organisationer "ude" i verden til at handle om, hvordan vores valg af iagttagelse konstant er med til at skabe og ja "genopfinde" vores organisationer og vores leder og medarbejderpositioner på særlige måder. Set ud fra et læringsperspektiv kan man sige, at dét, der bliver relevant, ikke er at tilegne sig mere eller bredere viden om "organisationen" eller om at effektivere overførsel af denne viden til de studerende. Med den tyske systemteoretiker Niklas Luhmann kan man sige, at det handler om at skabe den iagttagelse, der kan skabe de studerende, der konstant kan forstyrre deres egen iagttagelsesposition. Luhmann kalder det iagttagelse af anden orden. På den måde gør den poststrukturalistiske metapræmis op med det, nogen kalder tankpasserpædagogik (Keller \& Stegeager, 2011: 243), hvor læreren ses som den, der skal fylde intellektuelt brændstof på eleven, hvorefter den enkelte skal bære det fra klasserummet ud i praksis. Perspektivet gør også op med det Donald Schön kalder den tekniske rationalitet, der handler om, at uddannelsessystemet forstår sin pædagogiske opgave som et spørgsmål om applikation (Schön, 1987). Det vil sige, den studerende skal tilegne sig generaliserede metoder eller teorier som de efterfølgende kan anvende i praksis. Denne type af 'single loop ' læring (Argyris \& Schön, 1996) er også dominerende på mange lederuddannelser (se Pedersen \& Nielsen, 2011: 288 for den pointe). Det valgte perspektiv forsøger også at gå lige til kanten af perspektivisme (Pedersen \& Nielsen, 2011) og 'double loop' learning (Argyris \& Schön, 1978) forstået som det, at få de studerende til at diskutere forskellige teoretiske perspektiver i forhold til organisationen. Man kan sige, at perspektivisme såvel som 'double loop learning' handler om at kunne anvende forskellige teorier og om at kunne genkende mønstre i praksis med henblik på at ændre disse mønstre. Med afsæt i Niklas Luhmann vil jeg vise, hvordan iagttagelse på anden ordens niveau handler om at anspore de studerende til at få blik for, hvordan de selv - gennem deres valg af iagttagelse af organisationen er med til at konstituere den, dens roller, relationer, opgaver og løsninger. Der er naturligvis ikke tale om et enten/eller, men det er særligt den sidste del: Den studerende som 'den selv-refleksive iagttagelsesmaskine', der lægges vægt på i denne artikel. Det baner nemlig samtidig vejen for den præmis, at den studerende kan få blik for, hvordan hun selv er med til at skabe præmisserne for organisationen gennem 
hendes valg af iagttagelse. ${ }^{2} \mathrm{Og}$ så er vi tilbage ved debatten om behovet for at genopfinde den offentlige sektor.

\section{Iagttagelsesbegrebet}

Niklas Luhmann definerer iagttagelse som en operation, der markerer en side af en forskel og ikke en anden (Luhmann, 1993: 485). Pointen er, at den umarkerede side er lige så vigtig som den markerede, fordi den bestemmer, hvordan den iagttagede genstand viser sig for iagttageren. Idealet bliver med andre ord at give de studerende en indsigt $i$, hvordan deres valg af iagttagelse giver et særligt udsyn på organisationen og skaber særlige blinde pletter i forhold til andre udsyn på organisationen, og som samtidig er konstituerende for, hvad "organisationen" overhovedet bliver til. Lad os tage undervisning i organisationsteori som et eksempel. Når der undervises i bureaukratiet, markeres der en forskel mellem medarbejderens og lederens rolle. Lederen er den, der gennem regler udstikker en rolle til medarbejderen og medarbejderen er den, der tager rollen på sig. Bureaukratiet får netop denne betydning ved at være forskellig fra eksempelvis den lærende organisation, hvor lederen i højere grad forventes at supervisere og dermed være i øjenhøjde med medarbejderen. Hvad man kan iagttage er med andre ord afhængig af den forskel, der sætter rammen for iagttagelsen. Det vil sige med, Luhmanns iagttagelsesbegreb bliver det centrale ikke, ud fra en eller flere generaliserede modeller, at definere og diskutere, hvorvidt bureaukratiet er en organiseringsform, og den lærende organisation er et koncept. Det, der bliver centralt, er derimod at iagttage den forskel, vores forventninger om "organisationen" sætter. Alt bliver til et spørgsmål om at iagttage iagttagelser som iagttagelser, der sætter og konstituerer en forskel. I det følgende vil jeg folde ud, hvordan jeg tænker teknikkerne i figur 1 som en slags selvteknologi (Foucault, 1993). Forstået på den måde at jeg ikke ser dem som neutrale instrumenter til at få andre til at formidle eller anvende viden, men derimod som de generaliserede praksisser, der kan anråbe det enkelte subjekt som den, der kan iagttage sine (og andres) iagttagelser som iagttagelser, der skaber en konstituerende forskel.

\footnotetext{
${ }^{2}$ Hvorvidt dette i virkeligheden kan lade sig gøre, forholder denne artikel sig ikke til. Dens hovedærinde er at give et bud på, hvordan man kan bruge iagttagelsesbegrebet til at skabe betingelserne for en konkret undervisning.
} 


\section{Undervisningskonceptet - organisationen i et poststrukturalistisk perspektiv}

Sådan beskriver jeg undervisningen i undervisningsplanen:

\section{Figur 2}

\section{Mål:}

At introducere de studerende for hvordan man kan iagttage forholdet mellem organisation og individ på forskellige måder. Og at skabe en iagttagelsesstrategi der kan anskue, hvorledes de forskellige teorier og forestillinger om organisation og medarbejder har forskellige effekter for subjektivitet og magt og dermed for, hvordan ledelse overhovedet bliver mulig.

\section{Temaer/indhold:}

Undervisningen lægger ud med at tegne konturerne af Webers forestilling om den formelle organisation. Derfra spørger vi hvilke forestillinger om medarbejderen og organisationen, der er til stede, og hvilke effekter det har for ledelse.

På baggrund af Webers forestilling om bureaukratiet analyserer vi i grupper forskellige problemstillinger, som knytter sig til pædagogisk psykologiske praksisser, og spørger, hvordan Webers forestilling om bureaukratiet åbner forskellige løsningsmuligheder og, hvordan den skaber forskellige problemer.

Så træder vi et skridt tilbage gennem forelæsninger om andre og nyere teoretiske forståelser af forholdet mellem organisation og individ.

Herefter gennemføres nøjagtigt den samme $\varnothing$ velse men denne gang med en anden opfattelse af, hvad en organisation og et individ er. Det bliver nu tydeligt at et skift i metaperspektiv på organisation/individ ændrer på, hvad der er det organisatoriske problem og, hvad der er løsningsmulighederne.

Endelig vil vi forsøge at læse dagens undervisning bagfra med henblik på at oparbejde en iagttagelsesstrategi, der konstant kan gøre sig sensitiv overfor dets egen udsigelsesmulighed og refleksionskraft.

Som det burde fremgå sætter beskrivelsen af undervisningen tegn ${ }^{3} \mathrm{om}$, at de studerende bliver præsenteret for forskellige iagttagelser af, hvad en organisation er, og at de gennem øvelser skal afprøve, hvordan de forskellige iagttagelser producerer forskellige organisatoriske problemer og løsninger. Særligt introduktionen synes at være væsentlig, da den sætter tegn om, hvad de studerende kan forvente af undervisningen (for samme pointe se Meyer, 2005).

\footnotetext{
3 "At sætte tegn om" er en formulering, jeg bruger til at understrege den poststrukturalistiske pointe, at en beskrivelse af en undervisning ikke kun er en neutral beskrivelse af en begivenhed, der skal finde sted. Det er også en beskrivelse, der er med til at skabe betingelserne for den.
} 


\section{Konstruktionen af underviseren som leder af anden ordens iagttagelser}

Udover at præsentere mig selv begynder jeg som noget af det første, at fortælle om en personlig oplevelse jeg havde på et kursus i performance. Jeg fortæller eksempelvis:

"....en af de figurer, som gik igen på kurset, var en figur, som vi fik at vide kunne ligne Gandalf fra filmen Ringenes Herre. Helt konkret fik vi til opgave at lukke øjnene og at forestille os, at vi havde et brlte på af mod, en kappe af rummelighed, en krone af visdom som altid var til vores rådighed og en magisk stav $i$ hånden, der angav, at man altid ved, hvor man skal hen. Og når vi havde visualiseret, at vi var denne figur betød det, at vi kunne iagttage os selv og andre fra vores ekstraordinære tilstand. Visualiseringerne blev også brugt på andre tidspunkter. [...] Jeg skulle eksempelvis lagge mig på maven foran de andre, mens jeg hørte klassisk musik, og så skulle jeg forestille mig, at jeg løb ude i dyrehaven, og at jeg løb og løb og endelig fløj af sted, og at alt var så let så let. Og fra denne visualisering skulle jeg så begynde at rejse mig op igen og fortsætte den historie, jeg var i gang med. Og denne gang var stemmen en helt anden lige såvel, som tempoet var et helt andet. Og sådan var det med hver eneste øvelse og deltager...".

Der var flere grunde til, at jeg startede undervisningen med fortællingen om dette ekstraordinære kursus. Først og fremmest brugte jeg den til at illustrere undervisningens centrale omdrejningspunkt nemlig, at eksplosionen af styringsteknologier i den offentlige sektor sætter forholdet mellem organisationen og medarbejderen på spil, og at vi dermed ikke længere kan vide os sikre på, hvad en organisation og et medlemskab er (Andersen \& Born, 2004; Rennison, 2004; Raffnsøe, 2004; Pedersen, 2008; Rose, 1999; Dean, 1999). Pointen er, at det gør det interessant at kunne analysere, hvordan forskellige styringsteknologier iagttager og skaber præmisserne for, hvordan man kan iagttage organisationen og ledelse. Det forsøger jeg eksempelvis at understrege ved at afrunde historien på følgende måde: "Ser vi på dette i en organisationskontekst, bliver magt eller ledelse altså ikke (længere kun) muliggjort gennem lederens ordrer og instrukser, det bliver derimod muliggjort ved, at medarbejderen anspores til at skabe sig selv som ekstraordinær. Det er, når medarbejderen ser sig selv og andre som ekstraordinære, at den ekstraordinære og innovative organisation skabes. Det er selve forestillingen om det ekstraordinære, der muliggør ledelse".

Jeg bruger med andre ord fortællingen om visualiseringerne som en måde, hvorpå jeg søger at få dem til at gå med på den udfordring, at organisationsteori ikke længere (kun) handler om at forstå organisationen ud fra teorier, der på forhånd lægger sig fast på, hvad en organisation er. Derimod påstår jeg, at det handler om at kunne iagttage, hvorvidt og hvordan forskellige styringsteknologier iagttager og dermed også skaber organisationen og dens indbyggere. Dette syn på organisationens tilblivelse 
understøtter jeg desuden gennem diagnoser om eksempelvis den polyfone organisation (Andersen, 2001). Jeg kunne have valgt udelukkende at starte undervisningen med at henvise til, at "videnskabelige studier viser, at organisationer er polyfone og derfor taler med mange sideordnede stemmer". Når jeg ikke udelukkende gjorde brug af den mere traditionelle akademiske diskurs, var det ud fra en antagelse om, at en personlig fortælling kan vise, hvordan den polyfone organisation ikke kun bliver til gennem det, vi genkender som rationelle eller instrumentelle ledelsesdiskurser. Den bliver også til gennem vores egne iagttagelser af den.

\section{Konstruktionen af de studerende, der kan forstyrre deres egne og andres blikke} I forsøget på at skærpe de studerendes blik for, hvordan deres blikke på vores organisationer er med til at producere et særligt udsyn på organisationen og på, hvad der udpeges som udfordringer og løsninger, valgte jeg at gennemgå nogle forholdsvis karikerede perspektiver på, hvad en organisation er. Valget af teorier om organisationen blev: den bureaukratiske organisation, den feministiske organisation og den poststrukturelle/polyfone organisation. Jeg byggede særligt billederne af den bureaukratiske og den feministiske organisation op med hjælp fra Morgans Images of Organizations (Morgan, 2007). I min gennemgang af de forskellige perspektiver valgte jeg at fastholde fire centrale temaer som dem, der kan sige noget om, hvad en organisation er: Nemlig medlemskab, organisation, ledelse og ledelsesmetoder. Ved at skifte mellem de tre forskellige perspektiver, men samtidig fastholde blikket på nogle gennemgående temaer, ønskede jeg at reducere kompleksiteten. Tanken var, at det skærper deres mulighed for at iagttage forskellene på de forskellige perspektiver $\mathrm{i}$ forhold til, hvordan de skaber og iagttager udfordringer på særlige måder. Endelig var det væsentligt, at de studerende knyttede an til de første to teoretiske positioner, da den sidste position "den polyfone organisation" i højere grad forstyrrer billedet af, hvordan vi traditionelt forstår organisation som en enhed "derude", der har en entydig defineret grænse, der udpeger roller og kan afdækkes med de rette metoder. Startede jeg for tidligt med at gå i dybden med tekster, der forstyrrer forståelsen af organisationen som en afgrænset enhed, ville der være en risiko for, at de studerende ikke ville gå med på legen og præmisserne for undervisningen. Det ville minimere deres mulighed for at kunne iagttage og opleve, hvordan den iagttagede genstand, her organisationen, forandrer sig, når de studerende forskyder deres blik på den. Undervisningen og dens indhold var således også bygget op omkring en bevægelse, der gik fra at være mere genkendelige blikke på organisationer til at blive mere og mere forstyrrende blikke på forestillingen om organisationen som en fastdefineret enhed, der findes "derude" i virkeligheden adskilt fra vores iagttagelser. Den konstante forskydning af blikket på organisationen skulle anspore de studerende til at få øje på, hvordan de præsenterede teorier ikke er neutrale afspejlinger af virkelige organisationer men derimod er med til at skabe særlige organisatoriske udsyn, roller 
og ledelsesmuligheder. Det var forsøg på hele tiden at forstyrre iagttagelsen ved at gå fra første til anden - til tredje - ordens iagttagelser af organisationen. $\mathrm{Nu}$ vil jeg forsøge at vise, hvordan jeg forsøgte at skabe præmisserne for, at de selv begyndte at iagttage deres "egne" iagttagelser som iagttagelser, der skaber organisationens problemer og løsninger.

\section{Refleksionsøvelser - når iagttagelsesmaskinen sættes i spil}

Hver præsentation af en organisationsfigur blev afsluttet med den samme type refleksionsøvelse. Refleksionsøvelsen var bygget op omkring en sag, der netop på det tidspunkt havde stor opmærksomhed i medierne og som handlede om, at en journalist, der arbejdede undercover på en institution for mentalt handicappede, havde afsløret, hvordan pædagogerne havde talt nedsættende og aggressivt til beboerne. Jeg kaldte det "Strandvænget-casen". Jeg havde valgt denne case ud fra en viden om, at mange af de studerende kendte til de problematikker, der er forbundet med denne case. Kendetegnende for mange af de DPU-studerende på kandidatuddannelsen i pædagogisk psykologi er, at de er uddannet som professionsbachelorer og har flere års erfaring som socialrådgivere, pædagoger og lærere. Tanken var, at det skulle være en case, som de studerende personligt kunne involvere sig i, og at de skulle opleve, hvordan de forskellige blikke på organisationen kan forskyde deres 'personlige' udsyn på problematikken og åbne op for nye perspektiver på, hvad udfordringerne og problemerne er. Udover at præsentere casen og den problemstilling den rejste i medierne, valgte jeg også at italesætte dem som en ekspertgruppe af ledere, der skulle komme med et bud på, hvordan problemerne kunne løses. Jeg skrev på planchen: "Regionsformand Carl Holst, har nu besluttet at nedsætte jer som en ekspertarbejdsgruppe. Han udtaler til medierne: "Vi vil nu nedsætte en arbejdsgruppe med eksperter fra regionen, institutionerne og uddannelsessteder, som inden udgangen af april skal fremlægge en plan for, hvordan vi udvikler den pxdagogiske indsats i regionens tilbud til voksne udviklingshæmmede", regionsformand Carl Holst". Det vil sige, når jeg inddelte de studerende i grupper, så var det med henblik på, at de skulle anråbe sig selv som en ekspertgruppe. I denne gruppe skulle de først og fremmest svare på: "Diskutér med afsæt i den formelle organisation Strandvænget-sagen i forhold til følgende punkter: Hvad er problemet? Hvilke ressourcer/tiltag skal stilles til rådighed med henblik på at løse problemet? Hvilke egenskaber/kvalifikationer skal beslutningstageren have?") Spørgsmålene skulle lægge an til, at de studerende anvendte den formelle/bureaukratiske organisation som et udsyn på de problematikker, som Strandvænget-sagen producerede. I første omgang skulle de studerende således ikke reflektere over, hvad det betyder at iagttage organisationen fra den formelle organisation og dermed hvilket udsyn og blinde pletter, det producerer. De skulle 'bare' anvende perspektivet til at diskutere mulige løsninger. Øvelsen blev gentaget med den feministiske organisation. Pointen med at italesætte dem som ekspertgruppe var at få dem til at knytte an til idéen med øvelsen 
ved at føle sig betydningsfulde. Gik de udenfor den iagttagende forskel, som netop blev muliggjort gennem præsentationen af den bureaukratiske og den feministiske organisation, ville de miste de muligheden for at kunne iagttage den forskel, den konkrete teoretiske iagttagelse gør i forhold til at se og løse organisatoriske problemer. Kort sagt tilrettelagde jeg denne øvelse ud fra en præmis om, at man må iagttage på første orden, før man på anden orden kan iagttage, hvordan første ordens perspektiverne gør en forskel for, hvordan organisationen bliver til.

\section{Spejlinger i grupper - et medie til at installere iagttagelsesmaskinen}

Herefter bad jeg de studerende om at spejle deres svar i en anden gruppes svar. De studerende blev efter hver øvelse bedt om at skrive deres svar på plancher. På den måde kunne planchen 'fastfryse' deres svar og bruges til at formidle dem til en anden gruppe. Idéen var, at de studerendes fremlæggelser for hinanden, af henholdsvis den bureaukratiske og den feministiske organisations syn på Strandvænget-sagen, skulle synliggøre, hvordan de forskellige præmisser for at iagttage problemer er med til at forme løsningerne. Det skulle med andre ord være en metode til at vise, at den enkelte gruppes svar måske nok var originale, men at deres specifikke teoretiske iagttagelse af organisationen sætter en grænse for, hvordan man overhovedet kan løse de organisatoriske udfordringer. Spejlingen i grupper var således en måde, hvorpå jeg ønskede at få de studerende til selv at opleve, hvordan valget af det teoretiske perspektiv gør en forskel for de udfordringer, man ser, uden at jeg skulle påtage mig en faglig autoritet og fremføre og understrege det gennem referencer til eksempelvis såkaldt videnskabelige studier. Trækker man pointen lidt længere, var det en måde, hvorpå jeg ville anspore de studerende til ikke blot at få kendskab til diskursive analysestrategier (Andersen, 1999), der kan iagttage organisationer på forskellige måder. Jeg ville også gøre dem til 'selv-refleksive iagttagelsesmaskiner', der har blik for, at deres valg af iagttagelser producerer særlige udsyn på organisationen og dens medlemmer og dermed producerer særlige problemer og mulige løsninger. Ambitionen om at gøre dem til "selv-refleksive-iagttagelsesmaskiner", handlede igen om at ruste dem til fremadrettet selv at kunne reflektere over, hvilke iagttagelser de selv vil vælge og hvilke konsekvenser det har for, hvordan vi genopfinder, skaber og former den offentlige sektor.

\section{Poststrukturalistiske iagttagelser af organisationen}

Det sidste blik på organisationen, som de studerende skulle anvende, var det, jeg valgte at kalde et poststrukturalistisk perspektiv på organisationen. Her ville jeg anspore de studerende til at trække deres iagttagelser og deres viden om den bureaukratiske og den feministiske organisation tilbage. I stedet ville jeg anspore dem til at knytte an til den præmis, at deres brug af forskellige analysestrategier iagttager og skaber organisationen på forskellige måder og udelukker andre. Tanken var, at de i 
de foregående øvelser allerede havde banet vejen for den præmis, og at jeg nu kunne begynde at italesætte den eksplicit ved at henvise til forskellige videnskabelige, poststrukturalistiske studier. Således fremlagde jeg, hvordan de poststrukturalistiske studier af organisationer gør op med metoder til afdækning af viden 'derude' og i stedet taler om teori som diskursive analysestrategier, der kan iagttage og skabe noget og ikke noget andet (Andersen, 1999). Efter nogle eksempler på diskursive analysestrategier i forhold til konkrete studier, var det tanken, at de studerende selv skulle afprøve analysestrategierne i grupper i forhold til to små avisartikler om Strandvænget-sagen. Spørgsmålene lød nu: Analysér Strandvænget-sagen med udgangspunkt $i$ et eller flere spørgsmål: Hvilke styringsteknologier italesættes - og hvordan former de forholdet mellem organisationen/medarbejderen? Hvilke sociale kategorier (køn, alder, funktion m.m.) italesættes, og hvilke in- og ekskluderes? Hvem eller hvad udpeges som dem, der har ansvar for inklusion? Den øvelse viste sig at være markant sværere for de studerende end de to øvrige. Det gav sig udslag i, at de studerende i højere grad søgte min hjælp, når jeg gik rundt mellem grupperne. For nogle af grupperne lykkedes det at producere egentlige svar på spørgsmålene. Andre grupper brugte mere tid på at diskutere spørgsmålene og på at afsøge, hvad det egentlig betyder at stille spørgsmål på denne måde. Da grupperne kom tilbage i plenum gav jeg mit bud på, hvordan en analyse af avisartiklerne kunne se ud og dermed også mit bud på, hvordan artiklerne gennem deres valg af iagttagelse på "sagen" producerede organisationen på en særlig måde. De udpegede helte og skurke i den konkrete case og producerede 'nye' problemer og løsninger. Det var et forsøg på at illustrere, hvad perspektivet kan, men også et forsøg på at skabe refleksioner om, hvad det valgte perspektiv ikke kan iagttage. Pointen med Strandvænget-casen var således ikke, at det var en case, hvormed de studerende skulle diskutere for og imod, hvad de oplevede som den sande og adækvate beskrivelse af "hvad der i virkeligheden skete". "Casen" blev udelukkende brugt til at anspore de studerende til at få blik for, hvordan de forskellige teoretiske perspektiver har betydning for, de ledelsesudfordringer og de løsninger de udpeger og giver.

\section{At læse undervisningen bagfra}

Jeg afsluttede undervisningsdagen ved at anspore de studerende til at læse undervisningen bagfra. De skulle med andre ord også iagttage undervisningen som iagttagelser af iagttagelser af iagttagelser. Jeg spurgte således ud i lokalet: Hvordan har undervisningen sat præmisserne for vores iagttagelse af organisation og ledelse? På tavlen tegnede jeg et sildeben (se også Andersen, 1999) over de tre forskellige analysestrategier (den bureaukratiske, den feministiske og den poststrukturalistiske) og jeg endte med at italesætte, at de tre strategier ikke skulle læses som tegn på, at nogle strategier var bedre end andre, men som forskellige og ligestillede måder at iagttage organisationen på, som vi gentager og citerer i forskellige sammenhænge. I forlæn- 
gelse heraf afrundede jeg med, at hvis man vil se sine egne blinde pletter, når man vil iagttage organisationer og dens problemer og løsninger som medarbejder eller leder, ja så må man træde et skridt tilbage ved at spørge, hvilken iagttagelsesposition ser jeg nu organisationen ud fra - hvilken forskel sætter jeg?

\section{Afsluttende kommentarer}

Spørgsmålet er nu: Kan denne form for design af undervisning skabe de ledere (og medarbejdere), der kan håndtere styringspresset, polyfonien og de uddifferentierede og flydende systemer? En rapport der evaluerer en Diplomuddannelse i Ledelse ved at spørge lederne om, hvordan de så bruger de faglige perspektiver, der også er centrale i denne artikel, efter uddannelsesforløbet, svarer ja (Weinreich, Stæhr \& Mikkelsen, 2011). Lederne bliver bedre til strategisk at navigere i organisationer. De kan i højere grad proaktivt vælge deres iagttagelser og dermed, hvilken kasket og hvilket udsyn de har på organisationen og reflektere over iagttagelsens blinde pletter. Men et er, at de strategisk kan navigere i landskabet ved at have øje for, hvordan de selv (og andre) er med til at skabe det. Noget andet er, hvorvidt deres kompetence til at skabe proaktive strategier egentligt er med til at genopfinde den offentlige sektor? Det siger evalueringsrapporten - såvel som denne artikel - ikke noget om. Nærværende artikel siger udelukkende noget om, hvordan man kan "skrue op" for præmissen om, at vi selv er med til at skabe organisationen gennem vores valg af iagttagelse ved ikke kun at undervise i poststrukturalistiske tekster om ledelse men også ved at undervise på poststrukturalistisk. Hvis vi ikke vil lege med iagttagelser af iagttagelser som iagttagelser, der skaber organisatoriske udsyn og ledelseskasketter, må vi teoretisk stå et helt andet sted. Og sådan ender denne artikel - som undervisningen med at læse sig selv bagfra. Den ender med at ville forstyrre sine egne præmisser.

Christa Breum Amhøj er ansat som seniorforsker på CBS i SLIP-programmet, der har til formål at genopfinde ledelse af den offentlige sektor gennem eksperimenterende forskning. Hun er tidligere adjunkt på DPU og ph.d. i Management of Technologies fra Copenhagen Business School.

\section{Litteraturliste}

Amhøj, C. B. (2007). Det selvskabte medlemskab - om managementstaten, dens styringsteknologier og indbyggere. Forskerskolen i Ledelsesteknologi. CBS. Ph.D. serie 23. 2007.

Andersen, N. Å. (1999). Diskursive analysestrategier, København: Nyt fra samfundsvidenskaberne s. 197.

Andersen, N. Å. (2001). "Polyfone organisationer", CCC Working Paper, no. 6, 2001, 26 sider.

Andersen, N. Å., \& Born, A. (2001). Kærlighed og omstilling. Italesættelsen af den offentlige ansatte. København: Nyt fra samfundsvidenskaberne. 
Andersen, N. Å., \& Thygesen, N. T. (2004). "Styring af styringsværktøjer". Nordisk Administrativt tidsskrift, 1/2004, vol. 85.

Andersen, N. Å., \& Thygesen, N. T. (2004). "Styringsteknologier i den selvudsatte organisation", GRUS 73, vol. 25.

Andersen, N. A. (2003). "Organisation i anden ordens perspektiv - systemteoriensanalysestrategiske maskine“", in Højlund, Holger \& Knudsen, Morten. Organiseret kommunikation - systemteoretiske analyser. Københaven: Samfundslitteratur, pp. 310-323.

Argyris, C., \& Schön, D. (1996). Organizational Learning II: Theory, Method, and Practice. Reading MA: Addison-Wesley.

Argyris, C., \& Schön, D. (1978). Organizational Learning: A Theory of Action Perspective. Reading MA: Addison-Wesley.

Dean, M. (1999). Governmentality - power and rule in modern society. SAGE Publication s. 304.

Foucault, M. (1997). Ethics-subjectivity and truth, Essential works of Foucault 19541984, nr, 1. London: The Penguin Press.

Helth, P. (red.) (2011): Ledelse og læring i praksis. København: Samfundslitteratur.

Keller, H., Willert, S., \& Stegeager, N. (2011). "Efteruddannelse som ledelsesudfordring - på sporet af en akademisk praksisuddannelse", in Helth. P. (red.). Ledelse og læring i praksis.

Luhmann, N. (1993). "Observing Re-entries", in Graduate Faculty Philosophy Journal. New York: Department of Philosophy. The New School for Social Research, pp. 485-498.

Melander, Preben (red.) (2008). Det fortrængte offentlige lederskab - offentlig ledelse efter New Public Management. 1. udgave, Jurist- og Økonomforbundets Forlag.

Meyer, H. (2005). Hvad er god undervisning? København: Gyldendal.

Pedersen, D., \& Nielsen, J. C. R. (2011). "Deltagerorienteret lederuddannelse", in Helth, P. (red.): Ledelse og Læring i praksis.

Pedersen, D. (red.) 2004: Offentlig ledelse i managementstaten. Forlaget Samfundslitteratur.

Pedersen, D., Højlund. H., \& Greve, C. (red.) (2008). Genopfindelsen af den offentlige sektor Ledelsesudfordringer i reformens tegn. København: Børsens Forlag, s. 352.

Pedersen, O. K. (2011). Konkurrencestaten. København: Hans Reitzels Forlag.

Raffnsøe, S. (2004). "Ledelse, styring og stat fra antikken til moderne tid", in Offentlig ledelse i managementstaten. København: Forlaget Samfundslitteratur.

Rennison, B. (2004). "Ledelsesbegrebets historie i den offentlige sektor", in Offentlig ledelse i managementstaten. København: Forlaget Samfundslitteratur.

Rose, N. (1999). Powers of Freedom. Reframing Political Thought. Cambridge: Cambridge University Press.

Schön, D. (1987). Educating the Reflective Practitioner. San Francisco: Jossey-Bass.

Sløk, C., \& Villadsen, K (red.) (2008). Velfærdsledelse - i den selvstyrede stat. København: Hans Reitzels Forlag. 
Tangkjær, C., \& Thygesen, N. T. (2008). "Ledelse af styringspresset. To normative nedslag" i Sløk, C. \& Villadsen, K. (red.), Velfærdsledelse i den selvstyrende velfærdsstat. København: Hans Reitzels Forlag.

Weinreich, E., Stæhr, M., \& Mikkelsen, P. N. (2011). Professionalisering af ledelse; effekter og spor. En undersøgelse af Ringsted Kommunes lederudviklingsprojekt. Professionshøjskolen. UCC. 


\title{
Kollektiv Akademisk Vejledning \\ - et bud på en ændret organisering af vejledningen på universitetet
}

\author{
Rie Thomsen, adjunkt, Forskningsenheden for Vejledning på Institut for \\ Uddannelse og Padagogik, Arts, Aarhus Universitet. \\ Helle Merete Nordentoft, lektor, Forskningsenheden for Vejledning på In- \\ stitut for Uddannelse og Pcedagogik, Arts, Aarhus Universitet.
}

\begin{abstract}
Artiklen præsenterer et udviklingsarbejde: "Kollektiv Akademisk Vejledning" (KAV) på Master i vejledning på IUP (tidl. DPU), hvor studerende, som skriver individuelle opgaver, vejledes $i$ grupper. For at skabe sammenhæng mellem undervisning og vejledning og dermed kvalificere vejledningen beskriver vi, hvordan vi har integreret tre niveauer $i$ planlægningen af KAV. De tre niveauer er: Vejledningens placering $i$ organisationen, vejledningens forløb på den enkelte uddannelse og struktureringen af selve vejledningsrummet. Det er vores erfaring, at studerende, som deltager $i K A V$, fär en mere sammenhængende, dynamisk og udbytterig skriveproces. Opgaverne er skarpere, mere velskrevne, og de studerende klarer sig bedre til eksamen, fordi deres argumentation er gennemtænkt og afprøvet $i$ vejledningen. Som vejledere har vi farre henvendelser, fordi de studerende $i$ vid udstrækning er velinformerede og bruger hinanden, hvilket giver et bedre samvær mellem de studerende, som ofte bor langt fra hinanden.
\end{abstract}

"It is the tension between diverging voices that creates the potential for new understandings." (Dysthe, Samara, \& Westrheim, 2006).

Intro

Studiemiljøundersøgelsen 2011 på Aarhus Universitet viser, at mange studerende fortsat oplever, at manglende fællesskab og mangelfulde muligheder for faglig sparring er et grundlæggende problem på universitetet, og at nogle studerende fortsat oplever ensomhed på studierne. Undersøgelsen konkluderer, at der er behov for prioritering og nytænkning af vejledningen og dens organisering fx i form af flere forskellige vejledningsaktiviteter og øget brug af peer feedback. I denne artikel præsenterer vi et bud på en samlet og kollektiv vejledningsstrategi, som kan støtte studerende i at skabe større faglig og social sammenhæng i deres studieforløb. Vores argumenter for 
at udvikle en kollektive vejledningsform som pædagogisk praksis på universitetet bygger på følgende antagelser:

1. Kollektive vejledningsformer skaber rammer for videnskabelig argumentation og læring.

2. Studiemiljøet styrkes.

3. STÅ-produktionen øges, fordi kollektive vejledningsformer gør, at flere studerende bliver færdige til tiden.

Vi har valgt betegnelsen Kollektiv Akademisk Vejledning (KAV) for at understrege, at KAV er noget andet end gruppevejledning (se fig. 1). Endvidere har vi ønsket at sende et tydeligt signal om, at netop vejledningen er en central læringsaktivitet i forhold til at udvikle akademiske kompetencer. Formålet med KAV er at stimulere de studerendes studiemotivation og skrivelyst gennem at introducere en kollektiv akademisk arbejdsform via vejledning, hvor de studerende får erfaringer med at præsentere og diskutere faglige spørgsmål i et kollektivt forum. KAV praktiseres derfor i mindre grupper med mulighed for mundtligt med et skriftligt udgangspunkt at øve sig i færdigheder, som knytter sig til videnskabelige kompetencer, der er beskrevet i studieordningen. Ifølge studieordningen for vores uddannelseseksempel - Master i Vejledning 2010 - aflægger de studerende en mundtlig eksamen efter hvert modul, hvor eksaminator og censor vurderer de studerendes kompetencer til at:

- $\quad$ Vurdere centrale teoretiske og praktiske problemstillinger indenfor vejledning.

- $\quad$ Indgå i en teoretisk begrundet diskussion af disse problemstillinger.

- $\quad$ Argumentere for relevante udviklingsmuligheder indenfor undersøgelsesområdet.

Det er vores erfaring, at deltagelse i KAV giver de studerende mulighed for at udvikle og praktisere disse kompetencer.

Vi anvender citatet fra Dysthe til indledningsvist at udtrykke, at KAV bygger på, at en dynamik mellem flere forskellige stemmer skaber mulighed for nye forståelser. I en senere artikel skriver Dysthe og Lillejord desuden, at studerende lærer en central akademisk kompetence: “...by engaging in the most important craft of academic work, the productive process of giving and accepting critique. Not only does this result in better products, they also learn the procedures and standards of the academic community." (Lillejord \& Dysthe, 2008, p. 83). Da KAV bygger på en dynamik mellem forskellige teoretiske perspektiver og projekter kan denne vejledningsform netop danne afsæt for at udvikle de studerendes kompetencer $i$ at give hinanden kritik og dermed deres videnskabelig argumentation. Deltagelse i KAV forventes 
således at bidrage til, at de studerende socialiseres ind i og lærer de centrale akademiske kompetencer som studieordningen beskriver.

Tidligere forskning i andre kollektive vejledningsformer i masteruddannelser underbygger disse antagelser (Dysthe, et al., 2006). Den tidligere forskning diskuterer dog ikke den faglige vejlednings samspil med undervisningen og med andre vejledningstilbud på en uddannelse. Et af de centrale mål for KAV er at sætte fokus på, hvordan vejledning kan bidrage til at skabe en organisatorisk, strukturel og indholdsmæssig sammenhæng i de studerendes uddannelsesforløb gennem at integrere den faglige vejledning med den vejledning, de studerende har mulighed for at få i skrivecentret og med undervisningen på masteruddannelsen.

Artiklen falder i 3 dele. Først uddyber vi det læringsteoretiske fundament for Kollektiv Akademisk Vejledning. Dernæst uddyber vi, hvordan KAV praktiseres på Master i vejledning på IUP. Vi runder af med at pege på fremtidige forsknings- og udviklingsperspektiver.

Kollektiv Akademisk Vejledning: En gruppe i Kollektiv Akademisk Vejledning består af studerende som arbejder med forskellige projekter men har samme vejleder.

Gruppevejledning: En gruppe i gruppevejledning består af studerende som arbejder med samme projekt og har samme vejleder.

Fig. 1 Definition af Kollektiv Akademisk Vejledning og gruppevejledning.

\section{Læring som deltagelse i KAV}

Det teoretiske grundlag for KAV findes i sociokulturelle læringsteorier, hvor læring knyttes til deltagelse (Lave \& Wenger, 2007). Et sociokulturelt perspektiv indebærer et skift i fokus fra individet som lærende til læring som deltagelse i social praksis. Der lægges vægt på den gensidigt relationelle afhængighed mellem aktør og verden, virksomhed, mening, kognition, læring og indsigt. Denne læringsteoretiske position fremhæver, at "mening forhandles socialt, og at personer i virksomheder (forstået som handlinger) tænker og handler interesseret, engageret." (Lave \& Wenger, 2007 p. 46). Når læring knyttes til deltagelse i social praksis bliver det tydeligt, at den individuelle læring knyttes til mulighederne for at deltage (Dreier, 1999; Højholt, 1996), og dermed skærpes blikket for forskellige deltagelsesmuligheder i de forskellige læringsaktiviteter på universitetet så som forelæsninger, holdundervisning, studiegrupper og vejledning. Læringsaktiviteterne giver de studerende forskellige muligheder for deltagelse og dermed læring. Denne artikel tematiserer integrationen og samspillet mellem KAV og andre læringsaktiviteter. 
Kollektiv Akademisk Vejledning - et udviklingsprojekt på IUP

Udviklingsprojektet startede i 2009 på Masteruddannelsen i Vejledning på IUP (tidl. DPU). Fig. 2 nedenfor viser udviklingen i antallet af kollektive vejledningsgrupper.

\begin{tabular}{|l|l|l|}
\hline Semester & Modul på Master i Vejledning & $\begin{array}{l}\text { Antal vejledningsgrupper } \\
\text { (3-6 studerende og en vejleder) }\end{array}$ \\
\hline E2009 & Modul 1 og 3 & 4 grupper \\
\hline F2010 & Modul 2 og 4 & 9 grupper \\
\hline E2010 & Modul 1 og 3 & 14 grupper \\
\hline F2011 & Modul $2 \operatorname{og} 4$ & 8 grupper \\
\hline E2011 & Modul 1 og 3 & 11 grupper \\
\hline
\end{tabular}

Fig. 2 Antal vejledningsgrupper 2009-2011.

Som figuren viser, har antallet af kollektive vejledningsgrupper været stigende. Udviklingsprojektet har medført, at stort set al vejledning på masteruddannelsen i vejledning er bygget op over denne ramme. Vi er gået fra, at vejlederne hver for sig eksperimenterede med forskellige former for kollektiv tilrettelæggelse til, at vi nu har en fast model for planlægningen af vejledningen, som anvendes på alle moduler.

I vores arbejde med KAV har vi forsøgt at tage højde for de særlige vilkår, studerende på masteruddannelser har til forskel fra fx de fleste studerende på kandidatstudiet. De studerende på Master i vejledning ${ }^{1}$ kommer fra hele landet, og de arbejder sideløbende med, at de studerer, ligesom deres akademiske kvalifikationer er meget vekslende. Nogle har allerede en akademisk uddannelse, mens andre er meget usikre på, hvad der kræves. Vores erfaring er, at mange studerende først tager fat, læser og skriver den sidste måned inden aflevering, hvilket giver et øget pres på vejledningen i den periode. Med udviklingsprojektet KAV ønskede vi at styrke en akademisk kultur, som skaber sammenhæng imellem undervisning og vejledning på trods af, at de studerede ikke har deres daglige gang på universitetet. Ligeledes oplevede vi, at de studerende ikke var gode til at gøre brug af de læringsaktiviteter, som indgik i uddannelsen, eksempelvis benyttede ikke alle sig af skrivecentrets undervisning på modul 4, selvom dette var en del af det 'obligatoriske' undervisningstilbud. Akademisk Skrivecenter blev startet i foråret 2009 for at fremme de studerendes skriveprocesser. Skrivecenteret varetager især de problematiske skriveforløb og arbejder pri-

${ }^{1}$ På Master i vejledning, som vedrører forskellige former for vejledning, men primært uddannelses- og erhvervsvejledning, studievejledning, karrierevejledning og voksenvejledning er der 4 moduler på uddannelsen, 3 grundmoduler og masterprojektmodulet, som er det 4 . modul. 
mært med individuel vejledning og workshops. Samarbejde med skrivecenteret om de studerendes skriveproces kunne derfor styrke og kvalificere forløbet for de studerende på modul 1-3, der har behov for mere vejledning, end rammerne for KAV tillader, samt styrke deltagelsen i den undervisning, som skrivecentret udbyder til studerende på modul 4 på master i vejledning.

\section{Organisering af KAV}

KAV er ikke en metode, som foreskriver, hvad den enkelte vejleder skal foretage sig sammen med sine studerende, når de mødes. KAV kan nærmere betegnes som en ramme, som kan give vejlederen et blik for vejledningens samspil med andre vejlednings- og undervisningstilbud dels i organisationen og dels på den enkelte uddannelse. KAV fordrer dog, at vejlederen tilrettelægger sin vejledning, så de studerende får mulighed for at udveksle forskellige forståelser, tilgange og perspektiver. I udviklingen af KAV har vi været optaget af, at både vejlederne og de studerende får øje for de ressourcer, der er tilgængelige i fællesskabet personligt, professionelt og organisatorisk. Spørgsmålet var - og er - hvordan de studerende kan støttes bedre i forhold til at skabe mening og sammenhæng i deres opgaveskrivningsproces. Ved at tage højde for og integrere nedenstående 3 niveauer for Kollektiv Akademisk Vejledning er det vores erfaring, at vi bedre kan nå dette mål.

1. Vejledningen i organisationen

Samspil mellem KAV og andre læringsaktiviteter og instanser i organisationen $\mathrm{fx}$ akademisk skrivecenter og metodeseminarer (støttecenter/studievejledning mv.).

2. Vejledningen på den enkelte masteruddannelse

Vekselvirkning mellem KAV-møder med de studerende og netværksseminarer for vejledere på grundmoduler (1-3), hvor vejlederne mødes og udveksler spørgsmål og erfaringer som opstart og afslutning på et semester.

Work in progress seminarer på masterprojektmodulet med deltagelse af flere vejledere og studerende (modul 4).

3. Vejledningsrummet

Struktur på vejledningsforløbet i KAV, fokus på fællesskabets ressourcer og didaktiske muligheder. Det kan fx være samarbejds- og feedbackøvelser (Bager, 2008) eller reflekterende teams (Andersen, 2001). 
Kollektiv Akademisk Vejledning - modul 4 masterprojekt

Produktkrav: Skriftlig opgave 50 sider med krav om empiri. Mundtlig eksamination 45 min. Timenorm: 25 timer pr. studerende inklusive eksamination og forberedelse

\section{Opstartsseminar}

Vi udveksler og arbejder med jeres oplæg til masteropgaven. Målet er at gå fra vejledningssessionen med en foreløbig køreplan for det videre arbejde med masterprojektet.

- Valg af emne og motivation

Udkast til problemformulering

Udkast til en disposition for projektet. Hvilke teoretikere og metoder vil I gerne bruge? Hvil-

ken empiri - og hvorfor?

Tidsplan for skriveprocessen

Introduktion til vejledningsprocessen og til sparring med medstuderende?

\section{Workshop i skrivecentret}

\section{Midtvejsrespons}

Vi diskuterer disposition for opgaven og et udvalgt afsnit til respons (teori/analyse). Hvordan analyserer I jeres problemstilling? Ønsker for respons formuleres i spørgsmål der relateres til den vedlagte tekst.

\section{Work-in-Progress seminar}

På et WIP seminar får de studerende lejlighed til at

- Præsentere jeres projekt: Hvad er formålet med projektet, hvorfor og hvordan vil du undersøge det? Teoretisk og empirisk

- Få respons på projektet fra andre vejledere og medstuderende.

Under WIP seminaret

- Hver studerende skal opponere på ét masterprojekt.

- Vejlederne giver respons på et antal projekter, de ikke selv har vejledt.

Denne respons er desuden en fin forberedelse til de spørgsmål og emner, der evt. kan komme til eksamen. Kun de studerende, som sender et skriftligt materiale vil få denne respons under WIP. Studerende, som af forskellige årsager ikke sender materiale til WIP er velkomne til at komme og lytte på.

\section{Strukturen under WIP}

Hvert projekt får ca. 30 min, som er fordelt på følgende måde.

- Den studerende får 5 min. til en kort præsentation af hans/hendes aktuelle spørgsmål/behov. Hvorfor stiller jeg netop disse spørgsmål i det rundsendte materiale? (max 5 minutter).

- Den medstuderende, der opponerer, har nu 7 minutter. Husk den meget simple grundregel for konstruktiv kritik er: Ros-ris-ros. Som opponent må du gerne forholde dig til klarheden i formidlingen. Hvad er det, der undersøges? Hvilke metoder anvendes? Hvilke diskussioner kan rejses på baggrund af projektet? Hvordan ser du sammenhængen mellem disse? Er der passager, hvor du som læser savner viden? Formuler 3 centrale spørgsmål til projektet, som din medstuderende kan forholde sig til.

- Nu er det vejlederens tur til at komme med respons i 7 minutter.

- Til slut er der små 10 minutter til en afsluttende diskussion af de perspektiver, der er rejst indtil nu. Her kan andre medstuderende og vejledere få lejlighed til at komme med kommentarer/spørgsmål.

- Afslutningsvis spørger vi den studerende, hvad hans/hendes næste skridt i skriveprocessen er. Hvor har WIP seminaret bragt dig hen i din skriveproces?

Under opponeringen må opponenterne ikke afbrydes. Den studerende, som modtager respons kan sidde og lytte, skrive ned - og efter responsen får han/hun lejlighed til at stille uddybende spørgsmål/kommentere på det, som er blevet sagt. Det er en god idé at undgå lange forklaringer og i stedet spørge ind til, hvordan det er muligt at arbejde videre med de uklarheder, som opponeringen har rejst.

\section{Vejledningsgang:}

Vejlederne har afsat denne dag til vejledning af de studerende, som har brug for det. Via mail, telefon eller face2face.

Fig. 3 Plan over Kollektiv Akademisk Vejledning. 


\section{Vejledningen i organisationen}

I beskrivelsen af "vejledningen i organisationen" har vi har valgt at fokusere denne artikel på modul 4, som er det afsluttende modul på Master i vejledning, hvor ressourcerne til undervisning og vejledning er fordelt på flest forskellige personer. Ressourcerne til undervisning på dette modul tilfalder modul 4-koordinatoren, som udbyder to workshops om metode, og de tilfalder skrivecentret, som ligeledes udbyder to workshops.

En central udfordring på modul 4 har været, at de studerende (og vejlederne) så skrivecentrets workshops som et tilbud, de studerende kunne tage i mod eller lade være. Denne opfattelse har fx betydet, at mange studerende ikke har prioriteret deltagelse i disse workshops og ofte (for) sent i deres skriveforløb har taget kontakt med skrivecentret på vejlederens anbefaling. Integrationen af skrivecentrets workshops og metodekurset på modul $4 \mathrm{i}$ en samlet oversigt til de studerende sammen med KAV har bevirket, at de studerendes (og vejledernes) blik for samspillet mellem vejledning og de andre aktiviteter på modul 4 er blevet skærpet. Konkret har det betydet, at flere studerende på master i vejledning deltager i de forskellige læringsaktiviteter på modul 4.

Vores udviklingsarbejde peger således på, at der har manglet koordination mellem udbyderne af de forskellige læringsaktiviteter. Der kan nemt opstå problemer med sammenfald i datoer, sammenfald i indhold eller ved, at studerende fravælger aktiviteter, fordi de tror, at indholdet i nogle læringsaktiviteter er det samme, eller at de studerende tror, at aktiviteten ikke er en del af læringsaktiviteterne på deres uddannelse men derimod et generelt tilbud. Hvis KAV skal lykkes, er planlægning og koordination mellem de forskellige læringsaktiviteter nødvendig.

På modul 1-3, hvor vi også har tilrettelagt vejledningen som KAV, men selv planlægger undervisningen, har vi valgt at indarbejde KAV i de seminarer, vi udbyder. Typisk fordeler undervisningen på modul 1-3 sig over 10 dage fordelt på 4 seminarer. Vi har bemærket, at flere og flere studerende efterspørger datoer for kommende semestres undervisning (og vejledning og eksamen) sådan, at de kan få lagt dem ind i deres arbejdskalender. At vejledningen er en del undervisningsplanen sender et tydeligt signal om, at vejledning er lige så vigtig som forelæsninger. Denne prioritering understøtter de studerendes muligheder for at møde op til vejledningen, fordi datoerne er kendt på forhånd og derfor kan forhandles på plads med arbejdsgiver $\mathrm{i}$ god tid. Indlejringen af KAV i undervisningsplanen betyder, at flere møder op til vejledningen. 


\section{Vejledningen på den enkelte masteruddannelse}

I begyndelsen medførte ændringerne spørgsmål fra de studerende vedrørende rimeligheden af, at deres timer til vejledning blev samlet i en pulje og anvendt til en anden form for vejledning end den, de tidligere havde kendt eller forventede. Efterhånden som flere vejledere begyndte at anvende KAV som ramme for deres vejledning, fulgte en periode, hvor vi lod det være op til de studerende selv at vælge hvilken form for vejledning, de ønskede at deltage i. Denne form har vi forladt. I modsætning til Lillejord \& Dysthe (2008) tilbyder vi ikke eksplicit individuel vejledning på Master i vejledning. Dette har to begrundelser: For det første mener vi, at KAV giver de studerende mulighed for at deltage i aktiviteter, som gør det muligt at lære de kompetencer, som beskrives i studieordningen for master i vejledning. For det andet er timerne til vejledning begrænsede, og KAV er bygget op omkring, at timerne til vejledning anvendes $\mathrm{i}$ et fælles forløb og dermed ikke er til den enkelte studerendes rådighed og prioritering. Vi har en forventning om, at hvis vi lod det være op til de studerende at vælge mellem kollektiv og individuel vejledning, så ville mange vælge individuel vejledning af den simple grund, at det er det, de kender til. Vi har ønsket at gøre KAV til normen og den individuelle vejledning til undtagelsen. I praksis har det været sådan, at de studerende, som af forskellige årsager har efterspurgt et individuelt forløb fx pga. af afstand til DPU, arbejdsforhold eller andre begrundelser har fået individuel vejledning. Vi har dog opfordret dem til at følge de samme datoer som deres medstuderende, da vi oplever, at KAV samler vejledningen, sådan at vejledning af de studerende ikke kommer drypvis og spredes over mange dage. På den måde kan Kollektiv Akademisk Vejledning fungere som en ramme for vejledningen, der kan skabe mere sammenhængende og koncentreret vejledningstid for vejlederen og for de studerende. Samtidigt viser vores erfaringer, at studerende, som vejledes individuelt, også kommer tidligere i gang med deres opgaver, hvis de fleste studerende følger et KAV forløb.

\section{Vejledningsrummet}

I forhold til vejledningsrummet har vi formuleret nogle få centrale anvisninger for KAV. For det første bygger KAV på, at der udveksles perspektiver og forståelser i vejledningsrummet. Dysthe m.fl. betegner spænding mellem divergerende stemmer som fundamentet for nye forståelser (Dysthe, Samara \& Westrheim, 2006). Denne spænding har gode vilkår i KAV, da en gruppe udgøres af studerende som arbejder med at undersøge forskellige problemstillinger og ofte anvender forskellige teoretiske og metodiske tilgange i deres projekter. For at de studerende og vejlederen kan forberede sig til KAV, er det vigtigt, at de studerende forud for vejledningen udveksler skriftligt materiale. Materialet kan være mere eller mindre omfattende. Kravene til materialet er specificeret af vejleder mht. indhold og omfang. I det skriftlige materiale skal de studerende også formulere deres spørgsmål/vejledningsbehov for at 
skærpe de studerendes opmærksomhed på, hvad de gerne vil have ud af at deltage i vejledningen. For at vejledningen kan stimulere akademiske dialoger, er det vigtigt, at vejledningen bliver mere end en tilbagemelding på de studerendes materiale. Tid til fælles diskussion skal derfor indgå i vejlederens planlægning og styring af vejledningen. Vejledningen bliver mere varieret, end der har været tradition for, da der er en vekselvirkning mellem kollektive og individuelle input og øvelser. Netværksseminarerne viser, at KAV giver anledning til større variation i vejledningen. Denne variation kan betyde, at vejledningen når og tilgodeser flere forskellige læringsbehov hos de studerende. Samtidig siger vejlederne, at det kan være en udfordring ikke at falde tilbage til en asymmetrisk kommunikation i vejledningen, hvor vejlederen er eksperten, som giver feedback til hver enkelt studerende på skift, uden at inddrage de andre studerende i gruppen. Denne problematik har fået nogle vejledere til at efterspørge konkrete aktiviteter som fx struktureret feedback, feedback-spil, reflekterende teams mv. Flere vejledere har ganske enkelt sagt, at de oplever at mangle kompetencer til at inkludere forskellige aktiviteter i vejledningen og facilitere gruppeprocesser. KAV byder således på en række muligheder men er også forbundet med en række udfordringer. I punkterne nedenfor kommer vi derfor med anbefalinger til en vejleder, som ønsker at praktisere KAV.

- Vær tydelig om struktur, indhold og forventninger - også gerne indledningsvis og som afslutning på hver vejledningsgang.

- Vær opmærksom på, at alle får plads og respons til vejledningen.

- Sæt tid af til fælles faglige diskussioner, som udspringer af de konkrete projekter. Her træner de studerende argumentation med dig og med hinanden og udvikler akademiske kompetencer. (jf. målene i studieordningen).

- Vær opmærksom på at tilbyde deltagelsesmuligheder i den kollektive vejledning til usikre studerende (lav fx parøvelser).

\section{Fremtidige perspektiver}

Udviklingsprojektet Kollektiv Akademisk Vejledning har styrket vejledningens samspil med og placering i forhold til andre læringsaktiviteter på IUP. Ligeledes har KAV givet de studerende mulighed for at udvikle og praktisere kompetencer, som er nævnt i studieordningen for masteruddannelsen. KAV byder dog også på en lang række udfordringer for ønsket om at differentiere vejledning i et kollektivt forum, som vi dags dato stadigt arbejder med at håndtere og kvalificere i udviklingen af KAV. De vejledere, som har deltaget i udviklingsprojektet, har værdsat at mødes og udveksle erfaringer om vejledning på de to vejledermøder, vi har i forbindelse med 
KAV på de enkelte moduler. Disse møder og vejledernes ønske om at blive bedre til at vejlede kollektivt har resulteret $i$ et kompetenceudviklingsprojekt ${ }^{2}$, som har fået midler fra studiemiljøpuljen på IUP, Arts, i efteråret 2011. Senere er det vores håb, at der er interesse for at gentage kompetenceudviklingsprojektet på andre institutter på Arts.

Rie Thomsen er adjunkt ved Forskningsenheden for Vejledning på Institut for Uddannelse og Pædagogik, Arts, Aarhus Universitet. Centrale områder i Ries forskningsarbejde er karrierevejledning. Hendes afhandling Vejledning i fællesskaber har bragt inspiration til det danske vejledningsfelt ved at sætte fokus på: Hvordan vejledning far betydning $i$ de vejledtes liv, at en vejledning som foregår i fxllesskaber byder på andre deltagelsesmuligheder end en vejledning, som foregår individuelt og, at deltagerne $i$ vejledningen også påvirker og forandrer vejledningspraksis og derigennem skaber nye muligheder for den enkelte og for fxllesskabet. Hun har netop afsluttet en undersøgelse af efterskolernes vejledning, samt en artikel om dialektikbegrebet $i$ dansk, kritisk psykologi.

Helle Merete Nordentoft, er lektor ved Forskningsenheden for Vejledning på Institut for Uddannelse og Pædagogik, Arts, Aarhus Universitet. Helle er tidligere sygeplejerske, sundhedsfaglig supervisor og cand. comm. Kommunikation og kollektive vejledningsformer $i$ det sundhedsfaglige felt står derfor centralt $i$ hendes forskning. Omdrejningspunktet i forskningen er, hvordan vejledning - også i en universitetspædagogisk sammenhæng - gennem at bringe forskellige faglige/personlige perspektiver sammen kan skabe rammer for udvikling og læring.

Rie Thomsen og Helle Merete Nordentoft har sammen initieret et universitetspæedagogisk udviklingsprojekt om kollektive vejledningsformer, som har resulteret i udviklingen af Kollektiv Akademisk Vejledning som model for vejledning ved universitetet. Dette projekt videreføres $i$ en forbindelse med et projekt som dels søger at udvikle vejlederkompetencer i forbindelse med l kollektiv vejledning og dels undersøger kollegial vejledning som modus for udvikling og implementering af Kollektiv Akademisk Vejledning på universitetet.

\section{Litteratur}

Andersen, T. (2001). Reflekterende Processer. Samtaler og samtaler om samtalerne. København: Dansk Psykologisk Forlag.

Bager, L. T. (2008). "Cafemodellen: Anerkendende feedback i projektgrupper", in Dansk Universitetspædagogisk Tidsskrift, 3(6).

Dreier, O. (1999). "Læring som ændring af personlig deltagelse i sociale kontekster", in Nielsen K. \& Kvale S. (Eds.): Mesterlære. Kbh: Hans Reitzels Forlag.

${ }^{2}$ Projektet ledes af artiklens forfattere sammen med lektor Gitte Wichman-Hansen, AAU. I projektet optager vejlederne deres vejledning på video, vælger et klip og viser dette klip for de andre vejledere i projektet på netværksmøder. 
Dysthe, O., Samara, A., \& Westrheim, K. (2006). "Multivoiced supervision of master's students: a case study of alternative supervision practices in higher education", in Studies in Higher Education, 31 (3), 299-318.

Højholt, C. (1996). Udvikling gennem deltagelse Skolelivets socialpsykologi. København: Unge pædagoger.

Lave, J., \& Wenger, E. (2007). Situeret læring - og andre tekster. Kbh.: Hans Reitzels Forlag.

Lillejord, S., \& Dysthe, O. (2008). "Productive learning practice - a theoretical discussion based on two cases", in Journal of Education and Work, 21 (1), 75-89. 


\title{
Kompetence: Hvad, hvorfor, hvordan?
}

\author{
Anmeldelse af Birgitte Madelung \\ Knud Illeris: \\ Kompetence: Hvad, hvorfor, hoordan? \\ 1. udgave 2011. \\ Samfundslitteratur. \\ 170 sider.
}

Begrebet 'kompetence' anvendes efterhånden i mange kontekster og med det fælles udgangspunkt, at det handler om 'at kunne noget'. Samtidigt er det også et begreb, der kontinuerligt debatteres, da der ingen tydelig enighed er om definitionen af begrebet. 'At have kompetence til' har tidligere mere entydigt betydet at kunne bedømme og træffe beslutninger på andres og egnes vegne. I løbet af de sidste årtier har begrebet indtaget nye betydninger og er tæt knyttet til uddannelse og undervisning. Samtidig er begrebet også blevet en del af den politiske dagsorden, og det kan efterhånden forekomme lidt slidt, da det er et nemt begreb at hente ned fra hylden 'at alle skal have flere kompetencer'. Men det afholder heldigvis ikke kompetente forskere $\mathrm{i}$ at undersøge og arbejde med begrebet, og den seneste, som giver sit bud, er Knud Illeris, der stiller spørgsmålene: Hvad, hvorfor og hvordan?

Det er tre relevante spørgsmål, som vi også kan stille os selv i universitære sammenhænge. Siden 2006 har vi arbejdet ud fra Kvalifikationsrammen, som beskriver de videregående uddannelsers læringsudbytte. Læringsudbyttet opdeles i tre overordnende kategorier: Viden, færdigheder og kompetencer. Fokusset på læringsudbyttet ses tydeligt $\mathrm{i}$ formuleringen af studieordninger og fagbeskrivelser, hvor der er flyttet fokus fra pensum til målbeskrivelser, og derfor er det også relevant at kigge nærmere på, hvad disse kategorier indeholder, og hvordan der kan arbejdes med dem. Her kommer Knud Illeris' bog som et godt bidrag til den ofte lidt mindre konkrete, men ikke mindre væsentlige kategori af kompetencer.

Illeris har naturligvis sin definition på begrebet: Kompetence er "noget som alle udvikler i forhold til, hvad de beskæftiger sig med og ikke mindst, hvad de går op i" (p. 37). Det handler først og fremmest om at kunne handle "i relation til bestemte kendte, ukendte og uforudsigelige situationer" (p. 33). Det er altså egenskaber, man har tilegnet sig, som er forudsætninger for, at man kan handle i nye sammenhænge. Det leder tanken hen på Donald Schöns begreb 'indeterminate zones of practice', og Illeris sætter netop også fokus på handlingsorientering, som kompetencebegrebets væsentligste element. 
Fokus på handlingsorientering og praksiserfaring sætter nye perspektiver på udviklingen af undervisningen, og bogens væsentligste bidrag kommer i kapitel 7, hvor Illeris formulerer 'Kompetenceformlen'. Her udpeges tre nøgleord - 'engagement', 'praksis' og 'refleksion' - som udgør grundformlen i kompetenceudvikling. Illeris erkender selv, at den kan forekomme upræcis, men den ganske simple model beskriver meget fint igangsættelsen af læreprocessen, den praksis der understøtter kompetencetilegnelsen og endelig de afsluttende processer, der skaber overblik over processen og opnåelsen af de mål, der er blevet sat. Faktisk fremlægger Illeris to modeller i erkendelse af, at de ikke-erhvervsrettede uddannelser ikke har et praksisfelt, og praksis derfor er udskiftet med 'problem'. Illeris understreger, at det ikke er uden problemer, idet visse praksiserfaringer ikke kan erstattes.

Det er en ganske enkel model, Illeris bringer på banen, men den er ganske brugbar, og kan fint sidde som en lille huskeseddel på opslagstavlen inden undervisningen forberedes. Vi lærer ikke, uden vi er engagerede og har accepteret præmisserne, vi lærer ved den direkte handling, og vi skal altid forholde hos til vores handling gennem refleksion herunder ikke mindst feedback. Som undervisere er vi med til at finde engagementet, tydeliggøre præmisserne, skabe grundlaget for handlinger til at øve sig på og ikke mindst give feedback og understøtte den studerendes refleksion over handlinger og det lærte.

Illeris arbejder med et bredt kompetencebegreb og introducerer sin version af en kompetenceblomst. Den fremstår ikke som et konkret værktøj men er en visualisering af de elementer, der udgør en bred handlingskompetence eller det at kunne handle i bestemte situationer. I kapitel 2-5 gennemgår Illeris den række af kompetenceelementer, han medtager, og som han opdeler i generelle og udvidede kompetencer. Under de generelle finder vi elementer så som kundskaber og selvstændighed og af udvidede kompetencer nævnes bl.a. empati og modstandspotentiale. En sådan liste kan altid debatteres, men den giver et solidt billede af 'alt det andet', som vi implicit ofte forventer at de studerende kan.

Illeris lægger yderligere de elementer på, at vi hhv. har dispositioner 'for' og potentialer 'til' noget. Dispositioner har, ifølge Illeris, deres forankring i generne, men udvikles i individets kontekst. Potentialer til noget handler derimod om de forudsætninger, vi har udviklet for at tage vare på bestemte handlinger og opgaver. Set fra et undervisningssynspunkt er potentiale elementet interessant, fordi det sætter fokus på, hvordan vi understøtter udviklingen af handlingskompetence i vores arbejde med de studerende. Og netop, hvordan kompetencer udvikles, er fokus for kapitlerne 6-8. For dem, der har læst Illeris' Lxring (2006), er det genkendelsen som bidrager til læsningen af kapitel 6, og nye læsere får et behageligt overblik. Hovedkonklusionen er, ikke overraskende, at udviklingen af kompetencer forudsættes af læringens tre dimensioner: Indhold, motivation og samspil. Læringens tre dimensioner kan 
ifølge Illeris ikke adskilles, men han har altid fremhævet motivation som det afgørende parameter og understreger det her ved at citere Lennart Parknäs, som i 1976 opsummerede sit arbejde i en enkelt linje: "Det drejer sig ikke om at skabe motivation, men om at finde den." (p. 92).

Den største udfordring for en uddannelsesinstitution er Illeris' konklusion, at kompetencer ikke kan måles. Fordi de er konkret handlingsorienterede, vil en eksamen aldrig kunne verificere den buket af kompetencer, mange handlinger vil kræve. Vi kommer ikke væk fra eksamen som evalueringsform og blåstempling, men da vi også debatterer og udvikler undervisningen, skal vi også fortsat forholde os til, hvad eksamen kan og skal. Og det vil være ganske udbytterigt, hvis vi også accepterer, at ikke al læring kan og skal måles. Det er processen (etablering af engagement, praksis og feedback), som er vores fremmeste opgave som undervisere, og dette bør også åbne op for nye og læringsunderstøttende evalueringsformer.

Illeris' bog om kompetencer er et solidt bidrag til både debatten om kompetencer og til forståelsen af, hvordan vi lærer. Den er nem at gå til, og bogens tre afsnit kan læses separat. Den kan anbefales som oplæg til debat og inspiration, når undervisningen planlægges rundt omkring på de mange uddannelser, og den kan være med til at kvalificere brugen af kvalifikationsrammen, så kompetencer ikke bare bliver et element, der indskrives i studieordningerne, uden at det reelt bliver materialiseret. Læs den gerne sammen med dine kollegaer, for kompetencer udvikles ikke i enkelte fag, men bredt henover et uddannelsesforløb.

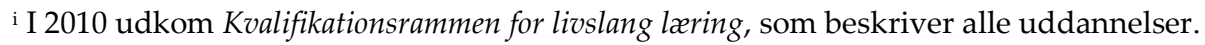




\title{
Et universitet er et sted, der forsker i alt - undtagen i sig selv og sin egen virksomhed
}

\author{
Anmeldelse af Palle Rasmussen
}

Karen Borgnakke:

Et universitet er et sted, der forsker $i$ alt - undtagen i sig selv og sin egen virksomhed. Rapport om den forskningsfaglige baggrund for udvikling af universitetspædagogisk forskning. Institut for Medier, Erkendelse og Formidling samt Institut for Nordiske Studier og Sprogvidenskab, Københavns Universitet, 2011.

99 sider.

Der er tale om en forskningsrapport, hvis formål er at kortlægge videnskabelige miljøer, forskningsprogrammer og forskningsgrupper inden for de universitetspædagogiske områder samt at give et overblik over hovedtendenser og eksempler på toneangivende og perspektivrige forskningsområder og projekter. Rapporten bygger først og fremmest på tilgængelig dansk litteratur og forskning på området fra 70'erne og frem men også på indtryk fra forskningsrejser til flere internationale centre for universitetspædagogik, hvoraf især miljøer ved universiteterne Oslo, Berkeley og Stanford præsenteres i rapporten.

Rapporten er opbygget i tre dele. Den første handler om universitetspædagogisk forskning 'som forskning' med behandling af dens videnskabelige forankring (som Borgnakke bl.a. ser som interdisciplinær), dens skiftende paradigmer og dens organisatoriske tilhørssteder. Anden del handler om tendenser og temaer i forskningsfeltet med hovedvægt på dansk sammenhæng men med inddragelse af internationale tilgange og eksempler. Afgrænsningen mellem første og anden del lyder måske ikke så entydig, og det er den heller ikke. Det er i vidt omfang samme litteratur, projekter og forskningsmiljøer som diskuteres i de to dele. Borgnakke forsøger at bruge paradigmer og paradigmeskift som indfaldsvinkel i første del, temaer og strategier som indfaldsvinkel i anden del. Det fungerer dog kun til en vis grad, og derfor kan det være svært at følge den røde tråd i de to første dele. Den tredje del, som er noget kortere, er lettere at læse, fordi den diskuterer potentialer i universitetspædagogisk forskning via behandling af tre bestemte forsknings- og udviklingsmiljøer: Nemlig Aalborg Universitet, den universitetspædagogiske enhed ved Universitetet i Oslo og forskningscenteret H-STAR ved Stanford Universitet.

Rapporten kommer vidt omkring. Borgnakke konstaterer i forordet, at det universitetspædagogiske felt "ikke sådan lader sig overskue". Det har hun ret i, og overskue- 
ligheden bliver ikke større af, at hun ikke kun vil fremstille den forskning, som eksplicit kalder sig selv universitetspædagogisk; hun vil også indplacere den i forhold til forskningen i uddannelse, pædagogik og læring mere generelt. Det er en rigtig bestræbelse, synes jeg. Man kan måske indvende, at flere af de universitetspædagogiske enheder, der har virket i Danmark de sidste 20 år, både i deres opgaver og deres medarbejderstab har haft begrænset tilhørsforhold til den institutionaliserede pædagogiske forskning. Men den universitetspædagogiske praksis og refleksion har alligevel trukket på forskningen og metoderne inden for didaktik, pædagogisk psykologi, læringsteori og andre dele af det pædagogiske forskningsfelt. Så det er prisværdigt, at Borgnakke anlægger det brede perspektiv; men det gør ikke kortlægningsopgaven lettere, og det har ikke øget overskueligheden i forskningsrapporten.

Det centrale i rapportens første del er forsøget på at lokalisere de væsentligste paradigmer, som har præget universitetspædagogisk forskning. Paradigmebegrebet, hentet fra Thomas Kuhn, præsenteres kort, og Borgnakke argumenterer for, at der i perioden 1970-2010 har eksisteret tre stærke paradigmer (s. 15), nemlig først det projektpædagogiske paradigme, dernæst læringsparadigmet samt endelig paradigmet universitet og samfund, som hun også kalder 'den politologiske vending' (s. 32). Der har selvsagt også eksisteret andre tilgange, men de har ikke haft sammenhæng og styrke nok til at fremstå som paradigmer. Borgnakke præsenterer og diskuterer især læringsparadigmet. Hun identificerer det med den angelsaksiske tradition, som har Paul Ramsden og John Biggs som centrale repræsentanter. Traditionen henter inspiration fra generel pædagogisk forskning, herunder ikke mindst Ference Martons læringsforståelse. Dette teoretiske grundlag bliver dog ikke videreudviklet, siger Borgnakke, derimod tages det som udgangspunkt for anvendelsesorienterede begreber og retningslinjer som f.eks. SOLO-taksonomien og 'constructive alignment'. Borgnakke finder, at Biggs-traditionen mangler udsyn og ikke tager højde for de mange andre tilgange til læring, som har præget den pædagogiske forskning de seneste 10-15 år, herunder sociokulturelle tilgange som situeret læring og mesterlære. Kritikken er relevant nok, men behandlingen af læringsparadigmet illustrerer samtidig, at Borgnakke kan være lidt for hurtig til at bevæge sig fra den nøgterne kortlægning af paradigmer til kritik af de positioner, hun ikke deler.

I rapportens anden del søger Borgnakke som nævnt at fremstille de temaer og strategier, som har præget den universitetspædagogiske forskning i perioden. Også her sker det i sammenhæng med uddannelsesforskningen i bredere forstand, hvor hun peger på en bevægelse fra 70'ernes kritiske analyser af forholdet mellem uddannelse og samfund på makroplan og på mikroplan over den gradvise opdagelse af temaer som kønnets betydning, etnicitetens betydning og uddannelse som system og organisation (s. 43). Det har nok en vis gyldighed for uddannelsesforskningen bredt, men jeg synes ikke det bliver dokumenteret, at denne bevægelse i samme grad har kende- 
tegnet universitetspædagogisk forskning. Mere interessant er behandlingen af de forskellige behov og interesser, universiteterne markerer i forhold til universitetspædagogik og universitetspædagogisk forskning. Eller måske snarere: Som universiteterne ikke markerer; for Borgnakke konstaterer flere gange, at hverken universiteterne selv eller de senere års strategiske uddannelsesforskning i nævneværdigt omfang har kvalificeret og styrket universitetspædagogikken (se fx s. 50 og s. 52). Hun finder, at især to spørgsmål er blevet forsømt: For det første spørgsmålet om, hvordan og i hvilke institutionelle rammer akademiske læreprocesser skal organiseres, og for det andet spørgsmålet om didaktisk og fagdidaktisk forskning og dennes rolle. I forhold til det sidstnævnte spørgsmål kan man indvende, at netop Biggs-traditionen, som Borgnakke identificerer med læringsparadigmet, vel nok så meget er en didaktisk tilgang, selv om den ikke knytter an til den tyske didaktik-tradition.

Hvad angår spørgsmålet om fagdidaktik, må man sige, at meget af den danske universitetspædagogiske forskning netop er fagdidaktisk i den forstand, at den er tæt knyttet til vidensindhold og forståelsesformer inden for bestemte fagområder som for eksempel matematik, ingeniørvidenskab og fremmedsprog. Problemet er ikke mangel på fagdidaktisk forskning men mangel på faglig sammenhæng mellem denne forskning og den generelle forskning i læring, uddannelse og pædagogik. Det er også Borgnakkes pointe, tror jeg.

Rapportens tredje del, med gennemgang og diskussion af udviklingen i tre bestemte forsknings- og udviklingsmiljøer, er instruktiv. Jeg må dog sige, at efter de mange kritiske kommentarer i første og anden del fremstår tredje del overraskende positiv og optimistisk på den universitetspædagogiske forsknings vegne. Borgnakke gør ganske vist tydeligt opmærksom på, at hun har udvalgt tre 'gode' eksempler; men også disse miljøer og centre har vel mødt og måttet forholde sig til de vanskeligheder og tvetydigheder, som bliver påpeget i rapportens første og anden del?

Man skal ikke læse denne rapport for at få et hurtigt overblik over den universitetspædagogiske forskning og dens udvikling. Den rummer bestemt bidrag til et sådant overblik; der er beskrivelser af udviklinger, miljøer og projekter, og en omfattende liste af referencer bliver nævnt og indplaceret. Men rapportens springende, komplekse og digressionsprægede fremstilling vanskeliggør overblikket. Man skal snarere læse rapporten som en række skarpe analyser af dilemmaer, vanskeligheder og potentialer i udviklingen af universitetspædagogisk praksis og forskning. Og som en samling af argumenter for den pointe, at universitetspædagogisk forskning må have en solid og reflekteret forankring i generel forskning om læring, uddannelse og pædagogik. Det er både en rigtig og en vigtig pointe. 


\section{DANSK UNIVERSITETSP ÆDAGOGISK TIDSSKRIFT}

\section{Årgang 7 Nummer 12/2012}

Tema: Udvikling af undervisning - rammer, barrierer og muligheder

Sponsoreres af Dansk Universitetspædagogisk Netværk

\section{REDAKTION}

Lektor Nina Bonderup Dohn (Syddansk Universitet) (ansvarshavende), Lektor Frederik Voetmann Christiansen (Københavns Universitet), Lektor Bettina Dahl Søndergaard (Aarhus Universitet), Pædagogisk konsulent Rikke von Müllen (Københavns Universitet), Lektor Gitte Holten Ingerslev (Aarhus Universitet), Lektor Anker Helms Jørgensen (IT-universitetet) 